\title{
Review \\ A Review of the Pharmacological Activities and Recent Synthetic Advances of $\gamma$-Butyrolactones
}

\author{
Joonseong Hur ${ }^{1}$, Jaebong Jang ${ }^{2, *}$ (D) and Jaehoon Sim ${ }^{3, *(1)}$ \\ 1 Natural Products Research Institute, Korea Institute of Science and Technology (KIST), 679 Saimdang-ro, \\ Gangneung 25451, Korea; hjs1120@snu.ac.kr \\ 2 College of Pharmacy, Korea University, Sejong 30019, Korea \\ 3 College of Pharmacy, Chungnam National University, Daejeon 34134, Korea \\ * Correspondence: jaebong_jang@korea.ac.kr (J.J.); jsim@cnu.ac.kr (J.S.); Tel.: +82-42-821-5938 (J.S.)
}

Citation: Hur, J.; Jang, J.; Sim, J. A Review of the Pharmacological Activities and Recent Synthetic Advances of $\gamma$-Butyrolactones. Int. J. Mol. Sci. 2021, 22, 2769. https:// doi.org $/ 10.3390 /$ ijms22052769

Academic Editor:

Czesław Wawrzeńczy

Received: 25 January 2021

Accepted: 3 March 2021

Published: 9 March 2021

Publisher's Note: MDPI stays neutral with regard to jurisdictional claims in published maps and institutional affiliations.

Copyright: () 2021 by the authors. Licensee MDPI, Basel, Switzerland. This article is an open access article distributed under the terms and conditions of the Creative Commons Attribution (CC BY) license (https:// creativecommons.org/licenses/by/ $4.0 /)$.

\begin{abstract}
Butyrolactone, a five-membered lactone moiety, is one of the privileged structures of diverse natural products and biologically active small molecules. Because of their broad spectrum of biological and pharmacological activities, synthetic methods for $\gamma$-butyrolactones have received significant attention from synthetic and medicinal chemists for decades. Recently, new developments and improvements in traditional methods have been reported by considering synthetic efficiency, feasibility, and green chemistry. In this review, the pharmacological activities of natural and synthetic $\gamma$-butyrolactones are described, including their structures and bioassay methods. Mainly, we summarize recent advances, occurring during the past decade, in the construction of $\gamma$-butyrolactone classified based on the bond formation in $\gamma$-butyrolactone between (i) C5-O1 bond, (ii) C4-C5 and C2-O1 bonds, (iii) C3-C4 and C2-O1 bonds, (iv) C3-C4 and C5-O1 bonds, (v) C2-C3 and C2-O1 bonds, (vi) $\mathrm{C} 3-\mathrm{C} 4$ bond, and (vii) $\mathrm{C} 2-\mathrm{O} 1$ bond. In addition, the application to the total synthesis of natural products bearing $\gamma$-butyrolactone scaffolds is described.
\end{abstract}

Keywords: $\gamma$-butyrolactone; pharmacological activities; lactone synthesis; lactonization; recent advances

\section{Introduction}

$\gamma$-Butyrolactone, a five-membered heterocycle containing ester functionality, has been broadly studied in the drug discovery field since it is one of the privileged structures of biologically active small molecules. Several $\gamma$-butyrolactone-containing drugs have been FDA-approved and used in clinic for diverse purposes such as diuretics, anticancer agents, contraceptive drugs, treatment of heart disease, and anti-glaucoma agents. $\gamma$-Butyrolactone moiety is also found in a variety of biologically active experimental drugs [1-4] and synthetic intermediates [5-10]. Moreover, numerous natural products, showing diverse biological activities, have $\gamma$-butyrolactone moiety.

The most universal synthetic method for $\gamma$-butyrolactone is intramolecular esterification, which can be readily utilized with substrates bearing $\gamma$-hydroxybutanoic acid functionality. However, diverse synthetic methodologies have been developed based on the discovery of biologically active synthetic or natural lactone drugs. Consequently, there have been many efforts to develop efficient synthetic methods to construct $\gamma$-butyrolactone, and several focused reviews have been published [11-14]. For example, Taylor and colleagues summarized new synthetic approaches for $\alpha$-methylene- $\gamma$-butyrolactones [12] and Marstral, Feringa and colleagues reviewed the catalytic asymmetric synthesis of $\gamma$-butyrolactone [13].

In this review, we first prepare a brief introduction of biologically active $\gamma$-butyrolactones including eight FDA-approved drugs (Table 1) and various natural and synthetic $\gamma$ butyrolactones that have broad biological activities such as anticancer, anti-inflammatory, antibiotic, antifungal, antioxidant activities as well as immunosuppressive, neuroprotective, 


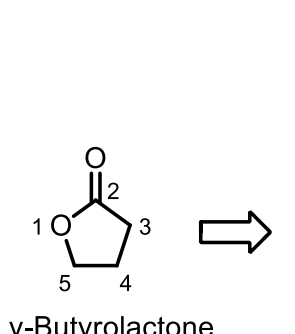

y-Butyrolactone

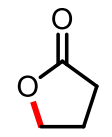

Section 3.1. C5-O1 bond formation
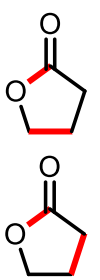

Section 3.2. C4-C5 and C2-O1 bond formation

Section 3.3. C3-C4 and C2-O1 bond formation and hypoglycemic activities (Table 2). Additionally, we summarize synthetic methodologies for the construction of $\gamma$-butyrolactone reported from 2010 to 2020, which are depicted in seven main sections based on the sites of bond formation (Figure 1). Each section is further divided into subsections according to the type of reaction and contains a description focused on the reaction mechanism. Additionally, applications of the reaction to the synthesis of complex molecules are included to demonstrate the synthetic utility of the reactions. The synthetic methodology has been continuously improving over the past decade. Therefore, this review will provide an update of recent work in the development of synthetic methods for the construction of $\gamma$-butyrolactones.

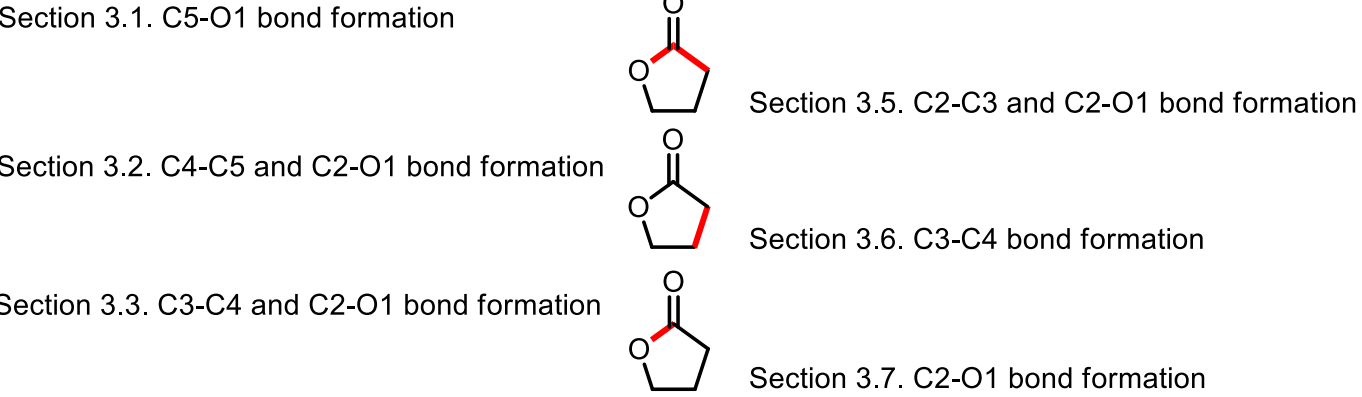

Figure 1. Bond disconnections for the synthesis of $\gamma$-butyrolactones.

\section{Pharmacological Activities of $\gamma$-Butyrolactones}

\subsection{Approved Drugs}

Several $\gamma$-butyrolactone-containing drugs have been FDA-approved and used in clinics for diverse purposes (Table 1). Pilocarpine, isolated from Pilocarpus microphyllus, is used to treat xerostomia and reduce eye pressure. (Entry 1) [15]. Pilocarpine is also widely applied to pharmacological research as a control cholinergic agonist. $\gamma$-Butyrolactone moiety was employed in a steroid skeleton at the $\mathrm{C}-17$ position to develop steroidal aldosterone antagonists (Entry 2 and 3). Spironolactone and eplerenone are common medications for cardiovascular diseases such as high blood pressure and heart failure [16,17]. Drospirenone, structurally similar with spironolactone, is used to prevent pregnancy as a progesterone agonist. (Entry 4) [18]. Podophyllotoxin, a natural DNA topoisomerase inhibitor from Podophyllum peltatum, is treated to kill genital warts (Entry 5) [19]. Two semisynthetic derivatives of podophyllotoxin, etoposide, and teniposide, were approved as anticancer agents used for lymphoma, leukemia, and various solid tumors (Entry 6 and 7) [20,21]. Vorapaxar, a derivative of himbacine, is a first-in-class protease-activated receptor-1 (PAR-1) antagonist (Entry 8) [22]. By inhibiting PAR-1, vorapaxar reduces thrombotic cardiovascular events and the risk of myocardial infarction. Now, several $\gamma$-butyrolactone-containing drug candidates have been investigated in clinical studies for the treatment of heart disease, rheumatoid arthritis, and infectious disease.

\subsection{Biologically Active $\gamma$-Butyrolactones}

\subsubsection{Anti-Inflammation}

Diverse butyrolactones have been studied to evaluate anti-inflammatory activities (Entry 1-9 in Table 2). Some of these butyrolactones modulate the NF- $\mathrm{KB}$ signaling pathway such as a santonine-derived butyrolactone that showed anti-inflammatory activity through the inhibition of the ubiquitin-conjugating enzyme, $\mathrm{UbcH} 5 \mathrm{c}$ (Entry 1 in Table 2) $[23,24]$. This anti-inflammatory activity was maintained in vivo using Freund's adjuvant arthritis rat model. A novel phthalide-based butyrolactone (Entry 2) [25,26] and two natural productscalcaratarin D (Entry 3) [27] and a sesquiterpene lactone (Entry 4) [28]—were also reported 
to inhibit activity of the NF- $\mathrm{kB}$ signaling pathway and showed anti-inflammatory activity. Among them, the in vivo activity of the first butyrolactone (Entry 2) was evaluated against the adjuvant arthritis rat. Moreover, a biyouyanagin derivative attached to adenine (Entry 5) [29] and arctiidilactone (Entry 6) [30] showed anti-inflammatory activity through the inhibition of LPS-induced cytokine production or LPS-induced NO production, respectively. A COX-2 inhibitor (Entry 7), which is an indole-based $\gamma$-butyrolactone, was reported to have shown anti-inflammatory activity with an $\mathrm{IC}_{50}$ value of $<0.001 \mu \mathrm{M}$ [31]. CD10847 (Entry 8) [32] and cinatrin C3 (Entry 9) [33] exhibited potent anti-inflammatory activities via inhibition of caspase- 1 or phospholipase A1, respectively.

\subsubsection{Anticancer}

The development of anticancer drugs is one of the long-term goals in the drug development field. Diverse natural and synthetic butyrolactones have been evaluated for their cytotoxic activities against various cancer cell lines. Protelichesterinic acid (Entry 10), a metabolite isolated from Antarctic lichens, showed cytotoxicity against HCT-116 cells with an $\mathrm{IC}_{50}$ value of $34.3 \mu \mathrm{M}$ [34]. P. K. Roy and colleagues isolated one of the cembrane-type butyrolactones (Entry 11) from the soft coral, Lobophytum, which displayed a strong cytotoxic activity against RAW 264.7 cells [35]. Sasaki and colleagues evaluated the AKT inhibitory activities of lactoquinomycin (Entry 12) [36,37], kalafungin (Entry 13) [36,38], and frenolicin B (Entry 14) [36,39], classified as pyranonaphthoquinone lactones, which were originally reported as antibiotics. These butyrolactones exhibited strong AKT inhibitory activities with $\mathrm{IC}_{50}$ values of $0.149 \mu \mathrm{M} \sim 0.313 \mu \mathrm{M}$ as well as cytotoxic activities with IC 50 values of $0.05 \mu \mathrm{M} \sim 0.07 \mu \mathrm{M}$ in MDA468 cells. A cytotoxicity of synthetic butyrolactones has been reported as well. Lee and colleagues synthesized an adenine-linked butyrolactone (Entry 15) which exhibited a cytotoxicity with an $\mathrm{ED}_{50}$ value of $0.3 \mu \mathrm{g} / \mathrm{mL}$ in L1210 cells [40]. Another example of synthetic butyrolactone, reported by Huth and colleagues, displayed strong HSP90 inhibitory activity $(\mathrm{Ki}=1.9 \mu \mathrm{M})$ which could result in the development of anti-cancer agent (Entry 16) [41].

\subsubsection{Antibiotic}

Many $\gamma$-butyrolactone-containing small molecules have been studied in the development of antibiotics. Lactivicin (Entry 17) [42,43], produced by two strains of bacteria, and one bicyclic butyrolacone (Entry 18) [44] showed strong inhibition of $\beta$-lactamase with $\mathrm{IC}_{50}$ values of $2.4 \mu \mathrm{g} / \mathrm{mL}$ and $15 \mu \mathrm{g} / \mathrm{mL}$, respectively. Moreover, various synthetic $\gamma$-butyrolactones exhibited potent antibacterial activities. For example, a synthetic $\alpha$-amino$\gamma$-lactone ketolide (Entry 19) showed excellent antibacterial activity against erythromycinsusceptible Streptococus pyogenes [45]. Additionally, hydrazonothiazolyl derivative (Entry 20) [46], $\beta$-cyclocitral derivative (Entry 21) [47], and $\alpha$-methylene- $\gamma$-butyrolactone (Entry 22) [48] displayed potent antibacterial activities and a synthetic $\beta$-aryl- $\delta$-iodo- $\gamma$ butyrolactone (Entry 23) exhibited bactericidal activity against Proteus mirabilis [49,50].

\subsubsection{Antifungal}

Researchers found that $\alpha$-methylene- $\gamma$-butyrolactone ring is a natural pharmacophore for antifungal natural products (Entry 24) [51]. Various synthetic $\alpha$-methylene- $\gamma$-butyrolactone analogues were synthesized and evaluated as potent antifungal agents. Feng's groups and Xing's groups found that $\alpha$-methylene- $\gamma$-butyrolactones bearing aromatic moiety at $\gamma$-position exhibited antifungal activity against Colletotrichum lagenarium (Entry 25,26) [52,53]. Höfle and colleagues isolated complex $\gamma$-butyrolactone natural product, leupyrrin A1 (Entry 27) from Sorangium cellulosum and found its potent antifungal activity [54]. Menche and colleagues reported the first total synthesis of leupyrrin A1 and SAR studies of leupyrrin analogues as potent antifungal agents $[55,56]$. 


\subsubsection{Immunosuppressive}

Two synthetic $\gamma$-butyrolactones and two natural products were reported to show immunosuppressive activities. Yang and colleagues found that benzene-fused $\gamma$-butyrolactones (Entry 28) demonstrate highly efficacious immunosuppressive properties [57]. A sesquiterpene lactone, isolated from Artemisia argyi (Entry 29), also exhibited potent immunosuppressive activity, which was assessed via inhibitory effect on the proliferation of Tlymphocytes [58]. A santonin derivative (Entry 30) reported by Chinthakindi and colleagues is another example of the immunosuppressant evaluated by T- and B-cell proliferation assay [59]. A natural $\gamma$-butyrolactone kinsenoside (Entry 31), originally isolated from Anoectochillus roxburghii, was reported as a potentially effective drug for treating patients with autoimmune hepatitis via targeting VEGFR2 to reduce the interaction between PI3K-AKT and JAK2-STAT pathways, which was confirmed in the vaccinated mouse model $[60,61]$.

\subsubsection{Neuroprotective}

Recent studies found that natural and synthetic $\gamma$-butyrolactones can be useful in the treatment of neurodegenerative disorders. Zhu and colleagues showed phenolic $\gamma$-butyrolactones in Cinnamomum cassia (Entry 32) exhibit a neuroprotective effect against tunicamycin-induced cell death in human dopaminergic neuroblastoma SH-SY5Y cells [62]. Guo and colleagues conducted similar studies and found that japonipene $C$ (Entry 33) is responsible for the neuroprotective effect of the extract of Petasites japonicas [63]. Bi and colleagues revealed that the $\gamma$-butyrolactone derivative 3-benzyl-5-((2nitrophenoxy)methyl)dihydrofuran-2(3H)-one (3BDO; Entry 34) protects against $\mathrm{A} \beta_{25-35-}$ induced cytotoxicity in the PC12 cell. 3BDO was proposed to exhibit the protective effect by inhibiting ROS production and autophagy process [64]. In vivo assay was performed to evaluate memory rescuing activity as well as the $\mathrm{A} \beta$ lowering activity of $3 \mathrm{BDO}$ in mouse brain [65]. These findings show $\gamma$-butyrolactone can be utilized as potential therapeutic scaffold for the treatment of Parkinson's disease and Alzheimer's disease.

\subsubsection{Antioxidant}

The antioxidant activity of $\gamma$-butyrolactones has been verified using 1,1-diphenyl-2picrylhydrazyl (DPPH) assay and superoxide scavenging assay. Lee and colleagues studied the antioxidant activity of styraxlignolide E (Entry 35) in Styrax japonica [66]. Boustie and colleagues found that norstictic acid (Entry 36) isolated from Usnea articulate shows superoxide scavenging activity higher than the well-known antioxidant quercetin [67]. The result suggested that this activity is involved in the antioxidant defense of lichens.

\subsubsection{Hypoglycemic}

The hyperglycemic activity of $\gamma$-butyrolactones has recently attracted attention as a possible therapeutic agent for type 2 diabetes. Lin and colleagues revealed that butyrolactone- 1 (Entry 37) inhibits $\alpha$-glucosidase in vitro and shows a potent TNF- $\alpha$ lowering effect [68]. The binding between butyrolactone- 1 and $\alpha$-glucosidase was theoretically proved in a molecular docking study. In an in vivo study on mice, potent hyperglycemic activity was maintained. Xiao and colleagues synthesized the analogues of butyrolactone- 1 by modifying side chains (Entry 38) [69]. A biological evaluation showed that butyrolactone-1 derivatives display inhibitory activity of protein tyrosine phosphatase 1B (PTP1B) which is a promising therapeutic target of type 2 diabetes. 
Table 1. Approved drugs containing $\gamma$-butyrolactone moiety.

\begin{tabular}{|c|c|c|c|c|c|c|}
\hline Entry & Name & Structure & Target Protein & Disease & Source & Reference \\
\hline 1 & Pilocarpine & & Muscarinic receptor & Xerostomia & Natural & [15] \\
\hline 2 & Spironolactone & & Mineralocorticoid receptor & $\begin{array}{l}\text { Heart failure, } \\
\text { Hypertension }\end{array}$ & Synthetic & [16] \\
\hline 3 & Eplerenone & & Mineralocorticoid receptor & $\begin{array}{l}\text { Heart failure, } \\
\text { Hypertension }\end{array}$ & Synthetic & [17] \\
\hline 4 & Drospirenone & & Progesterone receptor & Oral contraceptive & Synthetic & [18] \\
\hline 5 & Podofilox & & DNA topoisomerase II & Genital warts & Natural & [19] \\
\hline
\end{tabular}


Table 1. Cont

\begin{tabular}{|c|c|c|c|c|c|c|}
\hline Entry & Name & Structure & Target Protein & Disease & Source & Reference \\
\hline 6 & Etoposide & & DNA topoisomerase II & Lung cancer, Leukaemia & Synthetic & [20] \\
\hline 7 & Teniposide & & DNA topoisomerase II & $\begin{array}{l}\text { Lymphoblastic } \\
\text { leukaemia }\end{array}$ & Synthetic & [21] \\
\hline 8 & Vorapaxar & & Protease-activated receptor & $\begin{array}{c}\text { Thrombotic } \\
\text { cardiovascular events }\end{array}$ & Synthetic & [22] \\
\hline
\end{tabular}


Table 2. Representative biologically active $\gamma$-butyrolactones.

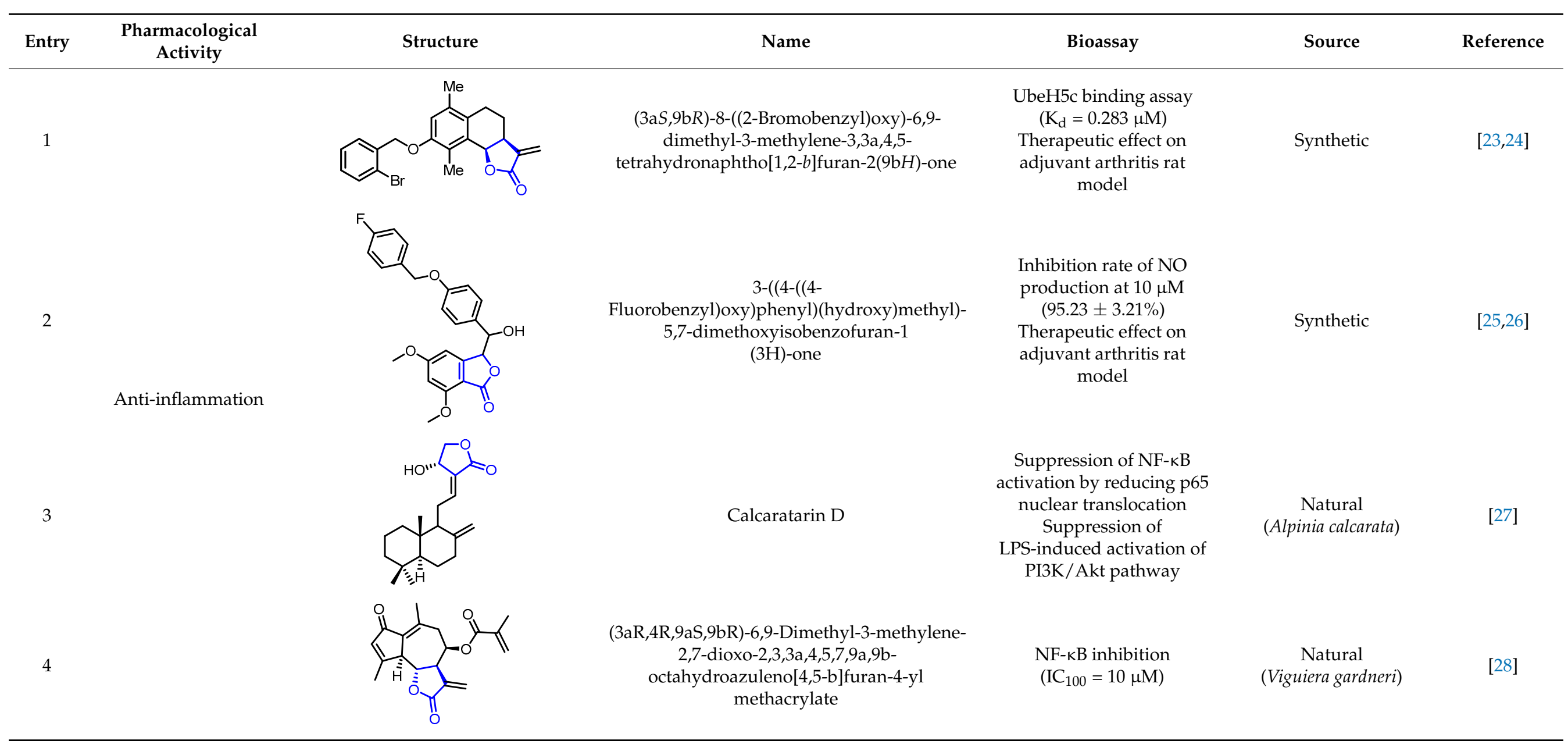


Table 2. Cont.

\begin{tabular}{|c|c|c|c|c|c|c|}
\hline Entry & $\begin{array}{l}\text { Pharmacological } \\
\text { Activity }\end{array}$ & Structure & Name & Bioassay & Source & Reference \\
\hline 5 & & & $\begin{array}{c}\left(1 R, 3 R, 4^{\prime} R, 5 R, 7 R\right)-7-((2,6-\text { Dichloro-7H-purin-7- } \\
\text { yl)methyl)-4'-methyl-1-phenyl-4'- } \\
\text { vinyldihydro-2' } H \text {-spiro[bicyclo[3.2.0]heptane- } \\
\text { 3,3'-furan]-2',4-dione } \\
\text { (Biyouyanagin analog) }\end{array}$ & $\begin{array}{l}\text { Inhibition of LPS-induced } \\
\text { cytokine production }\end{array}$ & Synthetic & [29] \\
\hline 7 & Anti-inflammation & & $\begin{array}{l}\text { 2-((2S,4S)-4-Hydroxy-5-oxo-4-(1-tosyl- } 1 H \text { - } \\
\text { indol-3-yl)tetrahydrofuran-2-yl)acetonitrile }\end{array}$ & $\begin{array}{l}\text { COX2 inhibition } \\
\left(\mathrm{IC}_{50}<0.001 \mathrm{uM}\right)\end{array}$ & Synthetic & [31] \\
\hline 8 & & & CD10847 & $\begin{array}{l}\text { Caspase-1 inhibition } \\
\quad\left(\mathrm{IC}_{50}=17 \mathrm{nM}\right)\end{array}$ & Synthetic & [32] \\
\hline 9 & & & Cinatrin C3 & $\begin{array}{c}\text { Phospholipase A2 } \\
\text { inhibition } \\
\left(\mathrm{IC}_{50}=70 \mu \mathrm{M}\right)\end{array}$ & $\begin{array}{l}\text { Natural (Circinotrichum } \\
\text { falcatisporum RF-641) }\end{array}$ & [33] \\
\hline
\end{tabular}


Table 2. Cont.

\begin{tabular}{|c|c|c|c|c|c|c|}
\hline Entry & $\begin{array}{c}\text { Pharmacological } \\
\text { Activity }\end{array}$ & Structure & Name & Bioassay & Source & Reference \\
\hline 10 & & & Protolichesterinic acid & Cytotoxicity in HeLa cells & $\begin{array}{c}\text { Natural } \\
\text { (Lichen metabolites) }\end{array}$ & [34] \\
\hline 11 & & & $\begin{array}{c}(1 \mathrm{a} R, 5 E, 8 E, 10 \mathrm{a} S, 13 \mathrm{a} S, 14 S, 14 \mathrm{a} R)-1 \mathrm{a}, 5,9- \\
\text { Trimethyl-13-methylene-12-oxo- } \\
1 \mathrm{a}, 2,3,4,7,10,10 \mathrm{a}, 12,13,13 \mathrm{a}, 14,14 \mathrm{a}- \\
\text { dodecahydrooxireno[2',3':4,5]cyclotetradeca[1,2- } \\
\text { b] furan-14-yl } \\
\text { acetate }\end{array}$ & $\begin{array}{l}\text { Cytotoxicity in RAW } 264.7 \\
\text { cell } \\
\qquad\left(\mathrm{IC}_{50}=5.99 \mu \mathrm{M}\right)\end{array}$ & $\begin{array}{c}\text { Natural } \\
\text { (Lobophytum sp.) }\end{array}$ & [35] \\
\hline 12 & Anticancer & & $\begin{array}{l}\text { Lactoquinoomycin } \\
\text { (Medermycin) }\end{array}$ & $\begin{array}{c}\text { AKT inhibition } \\
\left(\mathrm{IC}_{50}=0.149 \mu \mathrm{M}\right) \\
\text { Cytotoxicity in MDA468 } \\
\text { cells } \\
\left(\mathrm{IC}_{50}=0.05 \mu \mathrm{M}\right)\end{array}$ & $\begin{array}{c}\text { Natural } \\
\text { (Streptomyces K73) }\end{array}$ & {$[36,37]$} \\
\hline 13 & & & Kalafungin & $\begin{array}{c}\text { AKT inhibition } \\
\left(\mathrm{IC}_{50}=0.313 \mu \mathrm{M}\right) \\
\text { Cytotoxicity in MDA468 } \\
\text { cells } \\
\left(\mathrm{IC}_{50}=0.07 \mu \mathrm{M}\right)\end{array}$ & $\begin{array}{c}\text { Natural } \\
\text { (Streptomyces } \\
\text { tanashiensis) }\end{array}$ & {$[36,38]$} \\
\hline 14 & & & Frenolicin B & $\begin{array}{c}\text { AKT inhibition } \\
\left(\mathrm{IC}_{50}=0.198 \mu \mathrm{M}\right) \\
\text { Cytotoxicity in MDA468 } \\
\text { cells } \\
\left(\mathrm{IC}_{50}=0.06 \mu \mathrm{M}\right)\end{array}$ & $\begin{array}{c}\text { Natural } \\
\text { (Streptomyces roseofulvus } \\
\text { strain AM-3867) }\end{array}$ & {$[36,39]$} \\
\hline
\end{tabular}


Table 2. Cont.

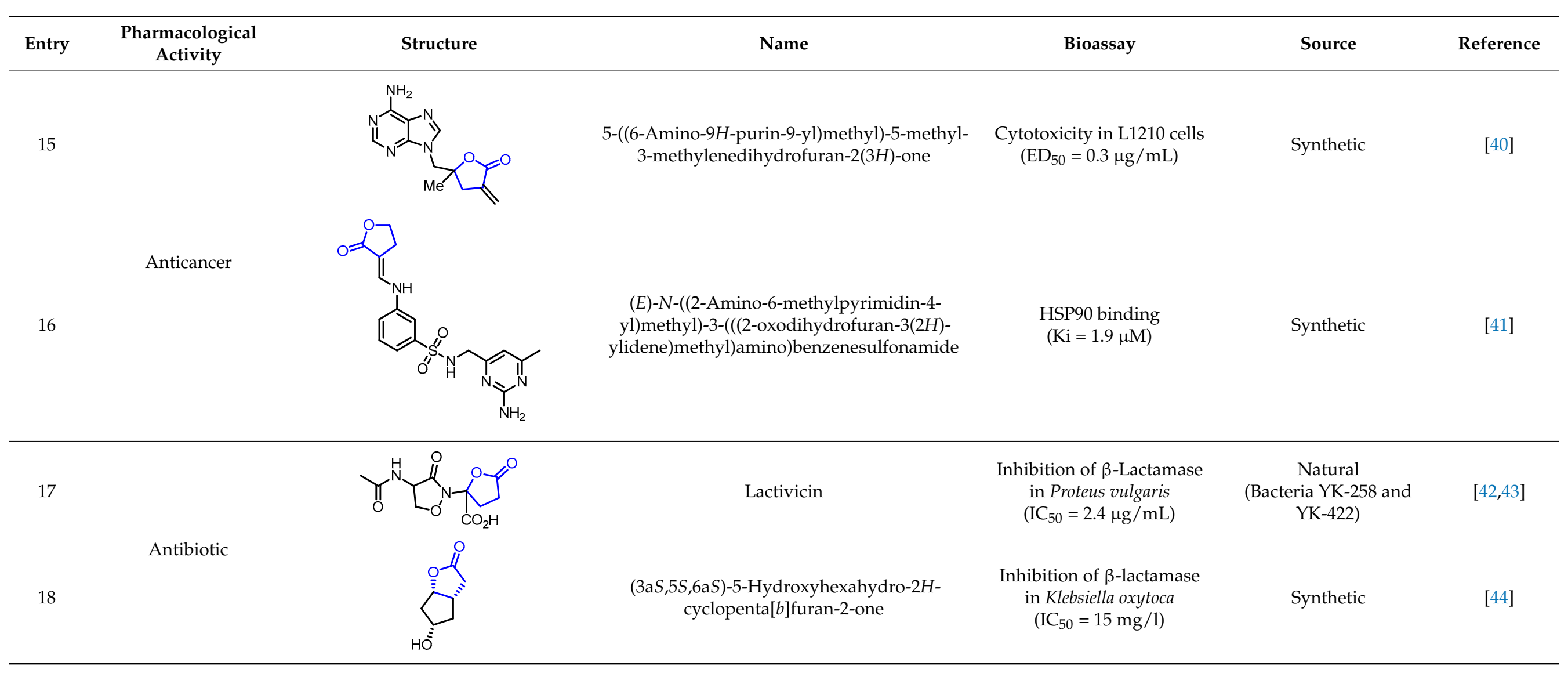


Table 2. Cont.

\begin{tabular}{|c|c|c|c|c|c|c|}
\hline Entry & $\begin{array}{c}\text { Pharmacological } \\
\text { Activity }\end{array}$ & Structure & Name & Bioassay & Source & Reference \\
\hline 19 & & & $\begin{array}{c}N-((3 R, 3 \mathrm{a} S, 4 R, 6 R, 8 R, 9 R, 10 R, 12 R, 15 R, 15 \mathrm{a} S)-9- \\
(((2 S, 3 R, 4 S, 6 R)-4 \text {-(Dimethylamino)-3-hydroxy- } \\
\text { 6-methyltetrahydro-2H-pyran-2-yl)oxy)-15- } \\
\text { ethyl-8-methoxy-4,6,8,10,12,15a-hexamethyl- } \\
\text { 2,5,11,13-tetraoxotetradecahydro-2H-furo[2,3- } \\
\text { c][1] oxacyclotetradecin-3-yl)-2-(quinoxalin-2- } \\
\text { ylthio)acetamide }\end{array}$ & $\begin{array}{l}\text { Antibacterial activity } \\
\text { against } \\
\text { erythromycin-susceptible } \\
\text { Streptococus pyogenes } \\
(\mathrm{MIC}=0.06 \mu \mathrm{g} / \mathrm{mL})\end{array}$ & Synthetic & [45] \\
\hline 20 & & & $\begin{array}{c}\text { 2-Ethoxycarbonyl-2-[2-(3-p- } \\
\text { chlorophenylthiazol-2- } \\
\text { yl)hydrazono]propyl-4,4-dimethylbutanolide }\end{array}$ & $\begin{array}{c}\text { Antibacterial activity } \\
\text { against Staphylococcus } \\
\text { aureus }\end{array}$ & Synthetic & [46] \\
\hline 22 & & & $\begin{array}{c}(1 \mathrm{a} R, 10 \mathrm{a} S, \mathrm{Z})-1 \mathrm{a}, 5 \text {-Dimethyl-8-methylene- } \\
\text { 2,3,6,7,7a,8,10a,10b- } \\
\text { octahydrooxireno[2',3':9,10]cyclodeca[1,2- } \\
\text { b]furan-9(1aH)-one }\end{array}$ & $\begin{array}{l}\text { Antibacterial activity } \\
\text { against MRSA } \\
\text { USA300 } \\
(\mathrm{MIC}=56.7 \mu \mathrm{M})\end{array}$ & Synthetic & [48] \\
\hline 23 & & & $\begin{array}{l}(4 S, 5 S)-5-((S)-1-\text { Iodoethyl)-4-(4- } \\
\text { isopropylphenyl)dihydrofuran-2(3H)-one }\end{array}$ & $\begin{array}{l}\text { Antimicrobial activity } \\
\text { against Proteus mirabilis } \\
(\mathrm{MIC}=0.25 \mathrm{mg} / \mathrm{mL})\end{array}$ & Synthetic & {$[49,50]$} \\
\hline
\end{tabular}


Table 2. Cont.

\begin{tabular}{|c|c|c|c|c|c|c|}
\hline Entry & $\begin{array}{l}\text { Pharmacological } \\
\text { Activity }\end{array}$ & Structure & Name & Bioassay & Source & Reference \\
\hline 24 & & & Carabrone & $\begin{array}{c}\text { Fungicidal activity against } \\
\text { C. lagenarium } \\
\left(\mathrm{IC}_{50}=7.10 \mu \mathrm{g} / \mathrm{mL}\right)\end{array}$ & $\begin{array}{c}\text { Natural } \\
\text { (Carpesium abrotanoides) }\end{array}$ & [51] \\
\hline 25 & & & 4- (3-Fluorophenyl)-2-methylenebutyrolactone & $\begin{array}{c}\text { Fungicidal activity against } \\
\text { C. lagenarium } \\
\left(\mathrm{IC}_{50}=57.9 \mu \mathrm{M}\right)\end{array}$ & Synthetic & [52] \\
\hline 26 & Antifungal & & $\begin{array}{l}\text { 4-[4-(3-Bromobenzoyloxy)phenyl]-2- } \\
\text { methylenebutyrolactone }\end{array}$ & $\begin{array}{c}\text { Fungicidal activity against } \\
\text { C. lagenarium } \\
\left(\mathrm{IC}_{50}=8.76 \mu \mathrm{M}\right)\end{array}$ & Synthetic & [53] \\
\hline 27 & & & Leupyrrins A1 & $\begin{array}{c}\text { Fungicidal activity against } \\
\text { M. hiemalis } \\
(\mathrm{MIC}=0.3 \mu \mathrm{g} / \mathrm{mL})\end{array}$ & $\begin{array}{c}\text { Natural } \\
\text { (Sorangium cellulosum) }\end{array}$ & {$[54]$} \\
\hline 28 & Immunosuppressive & & $\begin{array}{l}\text { (E)-3-(3,4-Dimethoxyphenyl)-N-(1-oxo-1,3- } \\
\text { dihydroisobenzofuran-5-yl)acrylamide }\end{array}$ & $\begin{array}{l}\text { Inhibition of } \mathrm{T} \text { cells } \\
\text { proliferation } \\
\left(\mathrm{IC}_{50}=0.029 \mu \mathrm{M}\right)\end{array}$ & Synthetic & [57] \\
\hline
\end{tabular}


Table 2. Cont.

\begin{tabular}{|c|c|c|c|c|c|c|}
\hline Entry & $\begin{array}{l}\text { Pharmacological } \\
\text { Activity }\end{array}$ & Structure & Name & Bioassay & Source & Reference \\
\hline 29 & & & $\begin{array}{l}\text { (4S,5S)-5-((1S,2S)-2-Hydroxy-2-methyl-5- } \\
\text { oxocyclopent-3-en-1-yl)-3-methylene-4-(3- } \\
\text { oxobutyl)dihydrofuran-2(3H)-one }\end{array}$ & $\begin{array}{l}\text { Inhibition of } \mathrm{T} \text { lymphocyte } \\
\text { proliferation } \\
\left(\mathrm{IC}_{50}=1.0 \mu \mathrm{M}\right)\end{array}$ & $\begin{array}{c}\text { Natural } \\
\text { (Artemisia argyi) }\end{array}$ & [58] \\
\hline 30 & Immunosuppressive & & $\begin{array}{c}(3 S, 3 \mathrm{a} S, 9 \mathrm{~b} R)-8-((1-(B e n z o[d][1,3] \text { dioxol-5-yl)- } \\
1 H-1,2,3 \text {-triazol-5-yl)methoxy)-3,6,9-trimethyl- } \\
\text { 3a,4,5,9b-tetrahydronaphtho[1,2-b]furan- } \\
2(3 H) \text {-one } \\
\text { ( } \alpha \text {-Santonin derivative })\end{array}$ & $\begin{array}{l}\text { Suppression of } \\
\text { LPS-induced B-cell } \\
\text { proliferation } \\
(50 \% \text { at } 10 \mu \mathrm{M})\end{array}$ & Synthetic & [59] \\
\hline 31 & & & Kinsenoside & $\begin{array}{l}\text { VGEFR2 binding } \\
\text { Therapeutic effect on } \\
\text { autoimmune hepatitis in } \\
\text { DCs/Hepa1-6 AIH } \\
\text { mouse model }\end{array}$ & $\begin{array}{c}\text { Natural } \\
\text { (Anoectochilus roxburghii) }\end{array}$ & {$[60,61]$} \\
\hline 32 & Neuroprotective & & $\begin{array}{l}\text { (3R,4R)-4-(4-Hydroxy-3-methoxyphenyl)-3-(4- } \\
\text { methoxyphenyl)dihydrofuran-2(3H)-one }\end{array}$ & $\begin{array}{l}\text { Neuroprotective activity in } \\
\text { SH-SY5Y cells }\end{array}$ & $\begin{array}{l}\text { Natural } \\
\text { (Cinnamomum } \\
\text { cassia) }\end{array}$ & [62] \\
\hline 33 & Neuroprotective & & Japonipene C & $\begin{array}{l}\text { Neuroprotective activity in } \\
\text { SH-SY5Y cells }\end{array}$ & $\begin{array}{c}\text { Natural } \\
\text { (Petasites japonicas) }\end{array}$ & [63] \\
\hline
\end{tabular}


Table 2. Cont.

\begin{tabular}{|c|c|c|c|c|c|c|}
\hline Entry & $\begin{array}{l}\text { Pharmacological } \\
\text { Activity }\end{array}$ & Structure & Name & Bioassay & Source & Reference \\
\hline 34 & & & $\begin{array}{c}\text { 3-Benzyl-5-((2- } \\
\text { nitrophenoxy)methyl)dihydrofuran-2(3H)-one } \\
\text { (3BDO) }\end{array}$ & $\begin{array}{l}\text { PC } 12 \text { cell viability assay } \\
\text { Alleviation of memory } \\
\text { deficits in A } \beta P P / P S 1 \\
\text { transgenic mice }\end{array}$ & Synthetic & {$[64,65]$} \\
\hline 35 & & & Styraxlignolide E & $\begin{array}{l}\text { DPPH Radical-Scavenging } \\
\text { Activity } \\
\left(\mathrm{IC}_{50}=194 \mu \mathrm{M}\right)\end{array}$ & $\begin{array}{c}\text { Natural } \\
\text { (Styrax japonica) }\end{array}$ & [66] \\
\hline 36 & & & Norstictic acid & $\begin{array}{l}\text { Superoxide scavenging } \\
\text { Activity } \\
\left(\mathrm{IC}_{50}=580 \mu \mathrm{M}\right)\end{array}$ & $\begin{array}{c}\text { Natural } \\
\text { (Usnea articulate) }\end{array}$ & [67] \\
\hline 37 & Hypoglycemic & & Butyrolactone I & $\begin{array}{l}\alpha \text {-Glucosidase inhibition } \\
\text { Multiple anti-type } 2 \\
\text { diabetic activities in } \mathrm{db} / \mathrm{db} \\
\text { mice }\end{array}$ & $\begin{array}{c}\text { Natural } \\
\text { (Aspergillus terreus) }\end{array}$ & [68] \\
\hline 38 & Hypoglycemic & & BL-3 & PTP1B Inhibitory Assay & Synthetic & [69] \\
\hline
\end{tabular}




\section{Synthesis of $\gamma$-Butyrolactones}

\subsection{Synthesis of $\gamma$-Butyrolactone via C5-O1 Bond Formation}

\subsubsection{Oxidative Lactonization of Pentenoic Acid}

The oxidative lactonization of alkenoic acid is one of the most popular transformations for the synthesis of lactone. A typical approach is usually initiated with the oxidation of olefin catalyzed by the highly toxic and expensive transition metal via the Prévost-Woodward reaction and Upjohn reaction conditions, and the subsequent intramolecular nucleophilic addition of carboxylic acid [70-72]. In contrast, recently reported methods for oxidative lactonization claimed metal-free and less toxic conditions, which utilized cheap and green organic catalysts and oxidants. These reactions have been developed with a view toward green chemistry.

In 2012, Gade and colleagues reported the triflic acid (TfOH)-catalyzed oxidative lactonization using peroxyacid as an oxidant (Figure 2) [73]. The cascade epoxidation of olefin 1 with peracetic acid and an intramolecular epoxide opening reaction provided $\gamma$-butyrolactone 2 . TfOH was proposed as a catalyst in both the ring-opening reaction via epoxide activation and acetylation of the subsequent hydroxyl group of $\gamma$ butyrolactone [74]. This method was applied to intramolecular lactonization as well as the intermolecular diacetylation of olefins. Considering the convenient process and the broad substrate scope, this might be an alternative approach to osmium tetroxide-catalyzed dihydroxylation of alkenes.

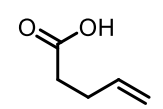<smiles>CCC(C)C(=O)O</smiles>

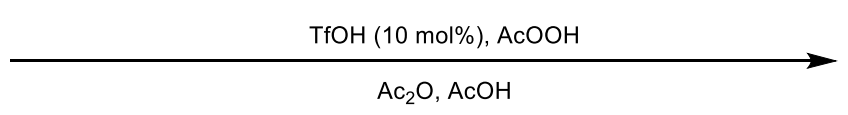

$\mathrm{Ac}_{2} \mathrm{O}, \mathrm{AcOH}$

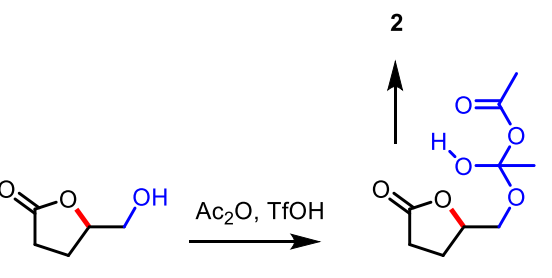

Figure 2. TfOH-catalyzed oxidative lactonization with peroxyacid.

Kang and colleagues also developed the $\mathrm{TfOH}$-catalyzed oxidative lactonization of alkenoic acid 3 (Figure 3) [75]. Instead of peroxyacetic acid, sodium periodate was used as an oxidant. This method showed a high tolerance for a broad range of $\alpha, \beta$ substituted pentenoic acid, providing the corresponding $\gamma$-butyrolactones 4 and bicyclic lactone scaffolds.<smiles>[R]C([R1])([R2])C([R])(C=C)C(=O)O</smiles>

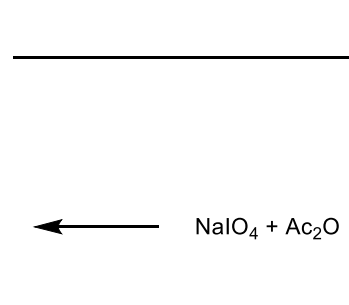

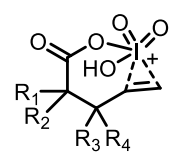

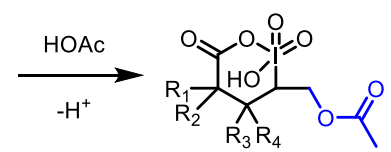<smiles>[R]C([R])([R])C([R])(C(=O)O)C1CO[C+](C)O1</smiles>

Figure 3. TfOH-catalyzed oxidative lactonization with sodium periodate. 
Furthermore, Kokotos and colleagues developed an oxidative lactonization catalyzed by an organocatalyst, which relied on the use of hydrogen peroxide as the oxidant with 2,2,2-trifluoroacetophenone 5 as the organocatalyst (Figure 4) [76]. Mild reaction conditions led to an environmentally and industrially friendly process.

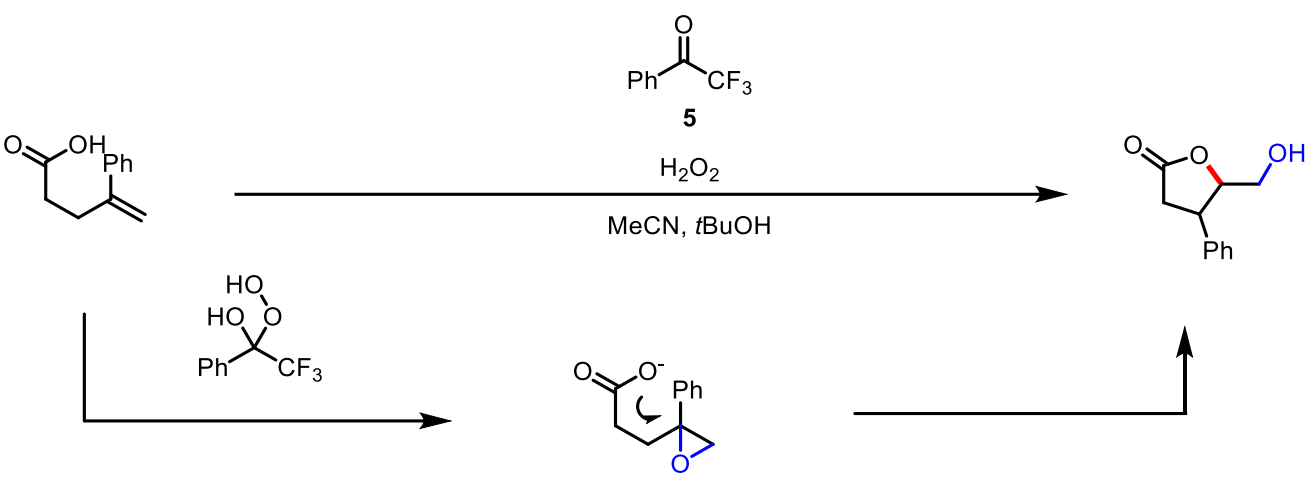

Figure 4. Trifluoroacetophenone-catalyzed oxidative lactonization with hydrogen peroxide.

The oxidative ring contraction strategy from 3,4-dihydropyran-2-ones 6 developed by Legault and colleagues using hypervalent iodine has been shown to provide 3,4-trans$\gamma$-butyrolactones 7 (Figure 5) [77]. The authors suggested that the hyperiodine reagent selectively reacts with trans-face to $\beta$-substituents of $\mathbf{6}$. This face selectivity generates iodinated intermediate 8 and the subsequent attack of a water molecule at the carbonyl position affords intermediate 9 . $\gamma$-butyrolactone 7 was diastereoselectively obtained through intramolecular substitution by carboxylic acid. The development of an enantioselective protocol was evaluated using a specific chiral iodine reagent.

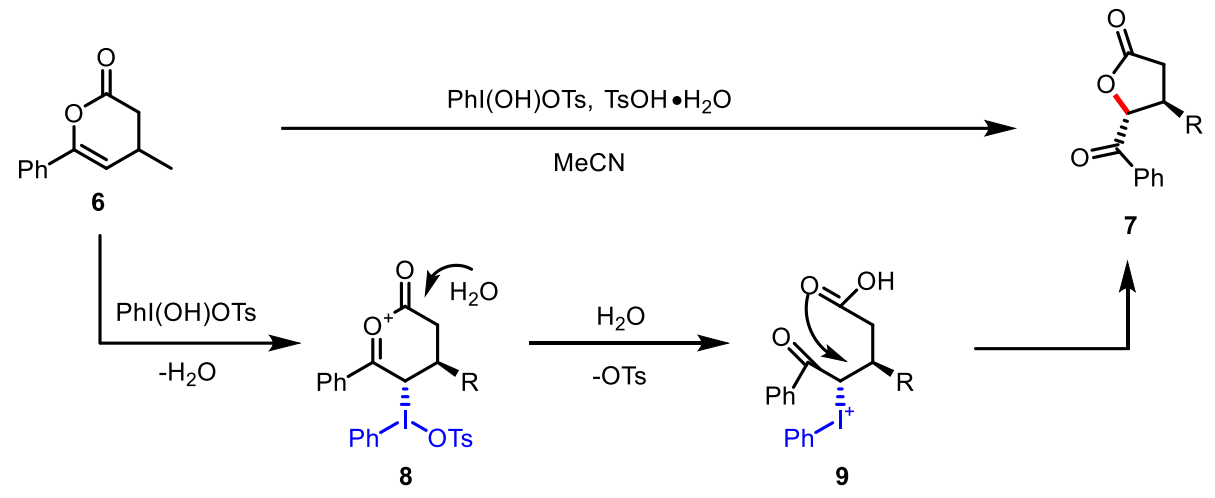

Figure 5. Oxidative ring contraction of 3,4-dihydropyran-2-ones.

As an analogous approach to oxidative lactonization, Dodd and colleagues reported aminolactonization with the use of in situ-generated nosyliminoiodane (Figure 6) [78]. The Cu-catalyzed generation of nitrene from arylsulfonyliminoiodane $\mathbf{1 0}$ was reported to yield aziridines from alkene groups $[79,80]$. For example, the aziridine intermediate 11, generated after the metal-catalyzed reaction of $t$-butyl ester 12 with iminoiodane 10, was successfully transformed into a high yield of amino $\gamma$-butyrolactone 13. The usefulness of this aminolactonization was exemplified by further annulation of butyrolactone in novel complex heterocyclic systems (Figure 6, bottom). 

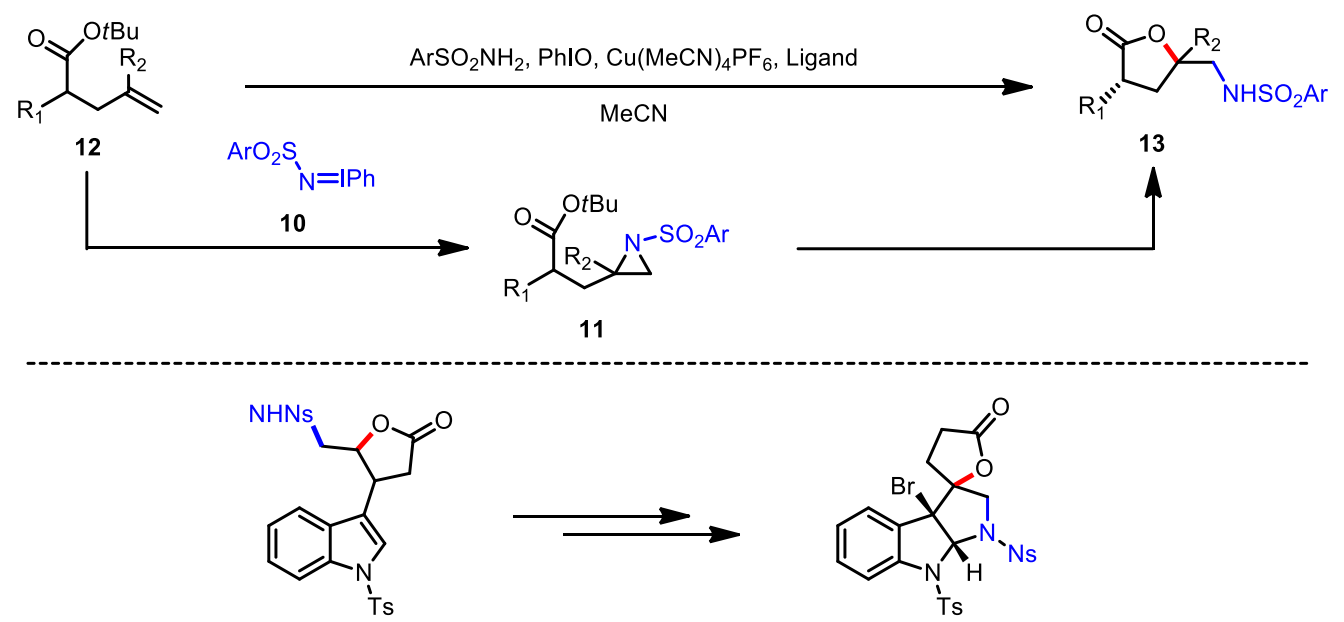

Figure 6. Aminolactonization of $t$-butyl pentenoate with iminoiodane (top) and the application of the resulting $\gamma$-butyrolactone (bottom).

\subsubsection{Halolactonization of Pentenoic Acid}

The halolactonization of alkenyl carboxylic acids is widely used to construct functionalized lactone skeletons, including $\gamma$-butyrolactone. Generally, electrophilic NXS (e.g., NBS or NIS) and halogens are utilized to activate olefin moieties [81,82].

In 2011, Togo and colleagues developed a sustainable electrophilic bromine source via umpolung of alkali metal bromide [83]. Bromide ( $\left.\mathrm{Br}^{-}\right)$from potassium bromide, one of the most abundant and stable bromide sources, is oxidized into bromonium ion $\left(\mathrm{Br}^{+}\right) \mathbf{1 4}$ by oxidation with Oxone. Encouraged by the success of intramolecular bromo-amination with in situ-generated bromonium ion, the use of this umpolung system in the bromolactonization of 4-pentenoic acid $\mathbf{1 5}$ has been investigated, resulting in the production of $\gamma$-butyrolactone moieties 16 (Figure 7) [84]. At this stage, the preference of the diequatorial conformation of the transition state over the diaxial form results in the diastereoselective production of cis-isomer $\mathbf{1 6}$. The utility of this approach was demonstrated by the total synthesis of dubiusamin C 19 from bromo butyrolactone 18, which was obtained by the bromolactonization of pentenoic acid 17.<smiles>[R]C(CC=C)C(=O)O</smiles>

15
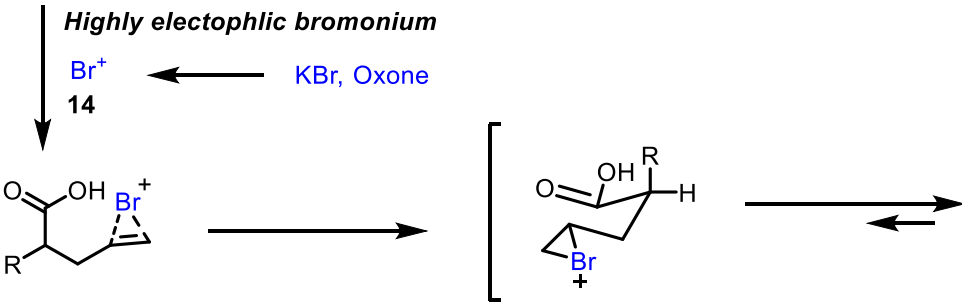<smiles>[R]C1C[C@H](CBr)OC1=O</smiles>

16

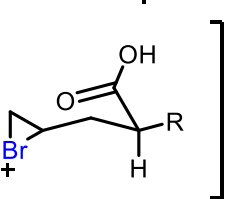<smiles>C=CC[C@H](C)C(=O)O</smiles>

18

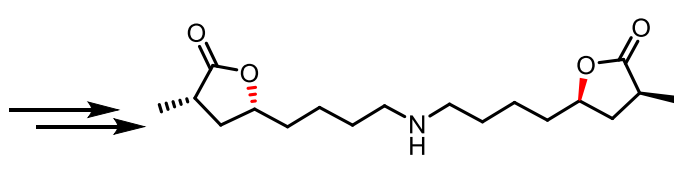

19, dubiusamine $\mathrm{C}$

Figure 7. Bromolactonization of pentenoic acid with $\mathrm{KBr}$ and Oxone.

Kumar and colleagues reported selenium-catalyzed bromolactonization by applying isoselenazolone 20 as a catalyst (Figure 8) [85]. Organoselenium compounds react with 
bromine to generate reactive bromoselenium intermediate $\mathbf{2 1}$, which has a greater reactivity than NBS and molecular bromine $\left(\mathrm{Br}_{2}\right)$ [86]. Several NMR studies confirmed that selenointermediate $\mathbf{2 1}$ plays a key role in the transfer of $\mathrm{Br}^{+}$to the olefins of 22. Intermediate $\mathbf{2 1}$ is catalytically regenerated in the presence of bromine or NBS with an inorganic base. This reaction allowed access to the construction of bromo butyrolactone 23 from a broad scope of pentenoic acids 22 .

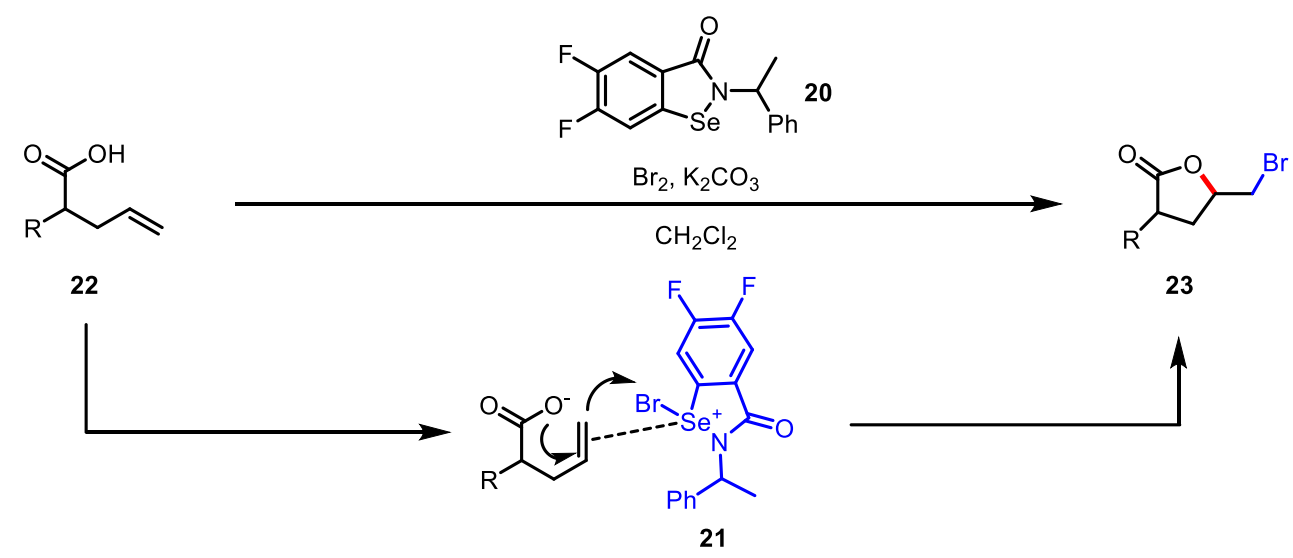

Figure 8. Bromolactonization of pentenoic acid with isoselenazolone.

\subsubsection{Acid-Promoted Cyclopropane Opening}

The electrocyclic ring-opening reaction of cyclopropane has been demonstrated as a powerful tool for the construction of fused cyclic systems with sequential intramolecular trapping [87]. Several acid-catalyzed, domino cyclopropane opening/carboxylic acid trapping reactions have been investigated to construct fused-butyrolactone systems.

In 2017, Reddy and colleagues reported a Brønsted acid-catalyzed cascade reaction for the construction of a tricyclic structure 26 bearing a $\gamma$-butyrolactone core (Figure 9) [88]. This interesting reaction starts with $p$-toluenesulfonic acid (PTSA)-catalyzed aldol condensation of diketone 24 to afford bicyclic enone $\mathbf{2 5}$, which subsequently undergoes acidcatalyzed cyclopropane opening/intramolecular trapping by an ester moiety.
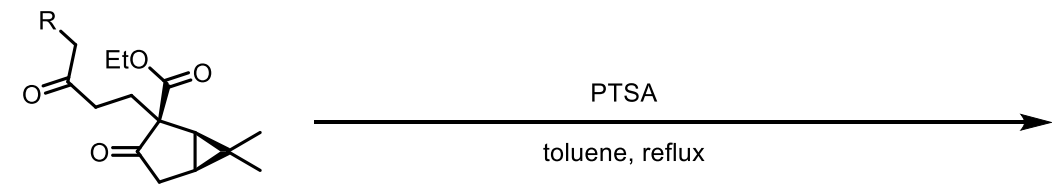

24

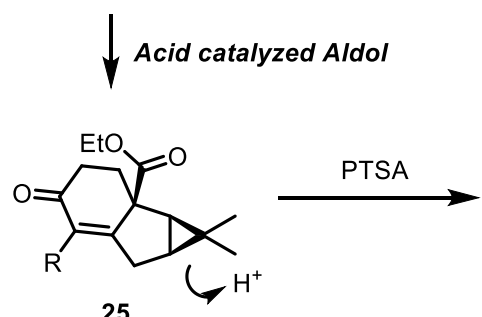

25 toluene, reflux

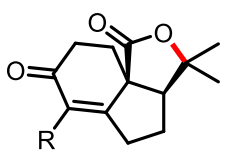

26

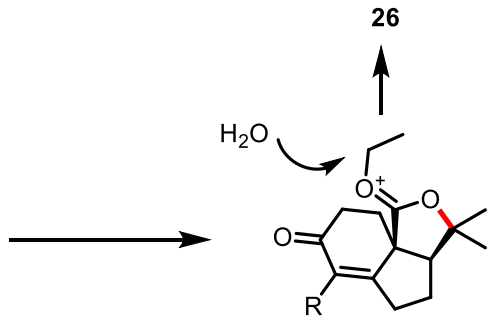

Figure 9. Acid-promoted cyclopropane opening/intramolecular ester trapping.

A similar domino reaction of silver (I)-mediated activation of dibromocyclopropane 27 /intramolecular acid trapping was developed by Batey and colleagues to form a transfused bicycle 28 possessing $\gamma$-butyrolactone (Figure 10) [89]. A unique trans-fused [5.3.0]system presented in pseudoguainolide natural products was selectively obtained. Computational studies demonstrated the preference of a trans-fused system over a cis-fused system. 


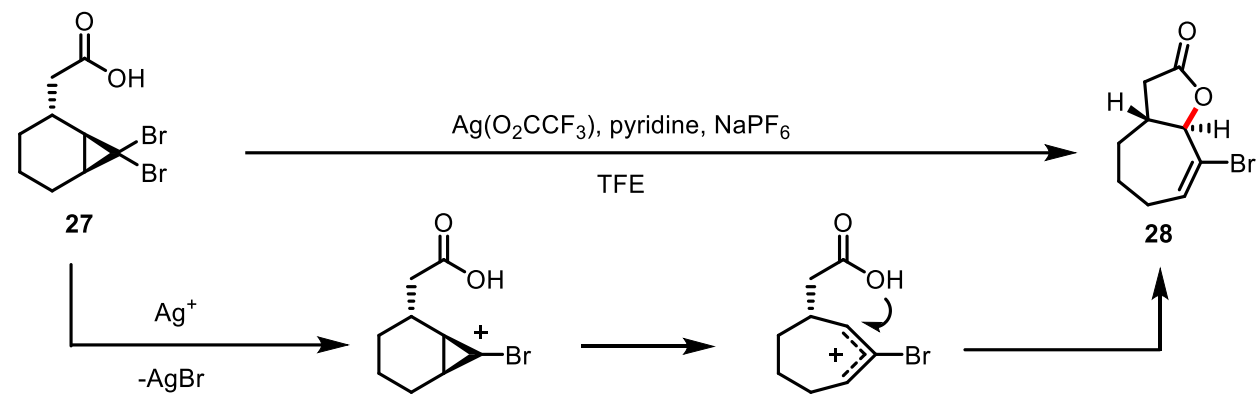

Figure 10. Silver-mediated cyclopropane opening/intramolecular acid trapping.

\subsubsection{Au-Catalyzed Oxaallylation}

Gold-catalyzed allylic functionalization has been the object of diverse cyclization reactions and has been found to be efficient for the preparation of $\gamma$-butyrolactone [90-92]. Chen and colleagues examined the Au-catalyzed lactonization of allylic acetate 29 to construct a butyrolactone system (Figure 11) [93]. The proposed mechanism involved the generation of an allylic cation intermediate $\mathbf{3 0}$ from allylic acetate $\mathbf{2 9}$ in the presence of the Au catalyst. The subsequent nucleophilic attack by the ester moiety resulted in the formation of bicyclic $\gamma$-butyrolactone 31 .

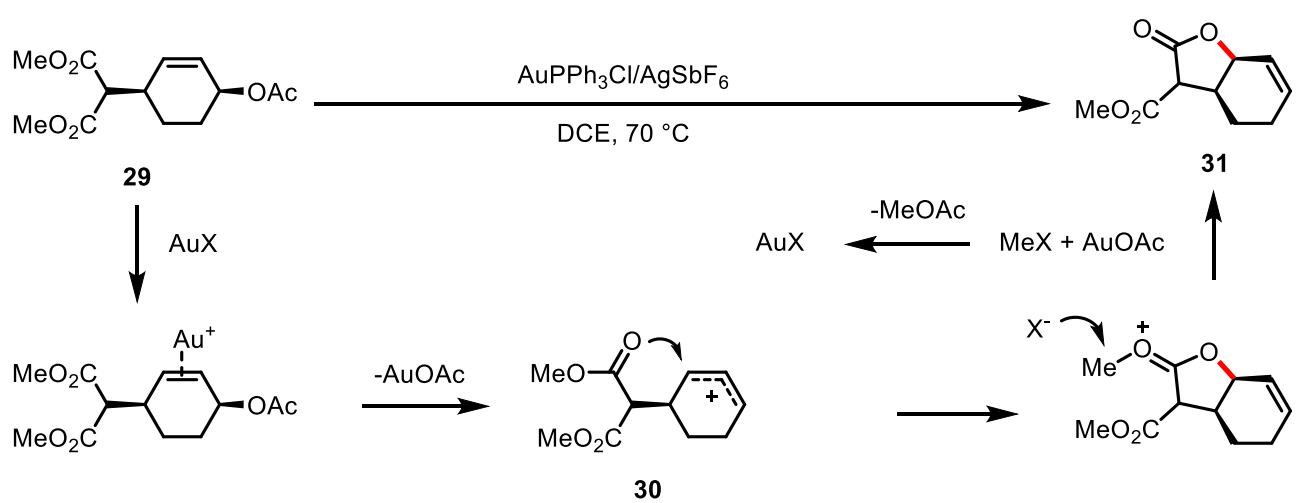

Figure 11. Gold-catalyzed intramolecular allylic alkylation of allylic acetate.

Bandini and colleagues reported the direct activation of free allylic alcohol 32 by applying a gold catalyst with $N$-heterocyclic carbene (Figure 12) [94]. An allylic cation intermediate is generated upon coordination of the NHC-gold complexes to a free allylic alcohol 32. The resulting poly-substituted $\gamma$-butyrolactone 33 was obtained via nucleophilic attack by ester and subsequent dealkylation.
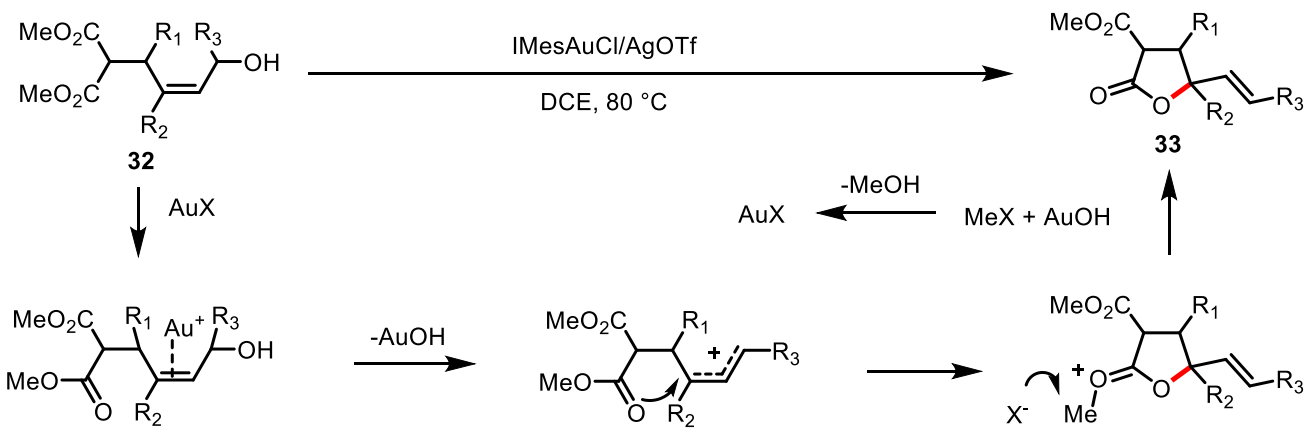

Figure 12. Gold-NHC complex catalyzed intramolecular allylic alkylation of allylic alcohol.

More recently, Aponick and colleagues developed a gold-catalyzed oxa-allylation of a free allyl alcohol 34 with an intramolecular free carboxylic acid to prepare $\gamma$-butyrolactone 
35 (Figure 13) [95]. In contrast to Brønsted acids generating a 7-membered lactone skeleton 36 via direct acid-catalyzed esterification, $\gamma$-butyrolactone $\mathbf{3 5}$ was obtained using a transition-metal catalyst via an $\mathrm{S}_{\mathrm{N}} 2^{\prime}$-type oxa-allylation mechanism.
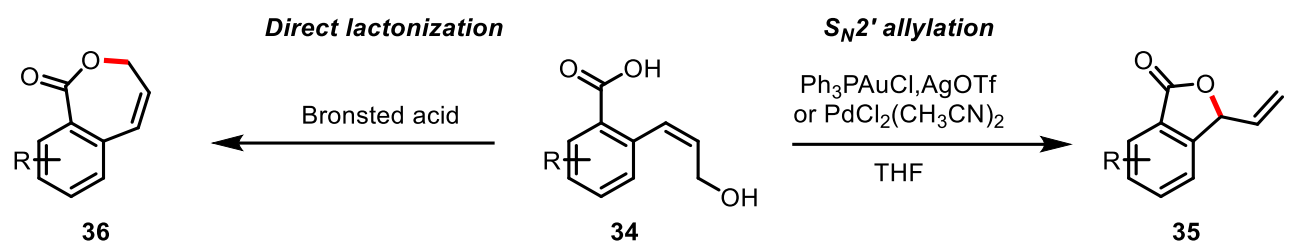

Figure 13. Gold-catalyzed dehydrative lactonization.

Allenylglycine 37 was also used as a precursor for the construction of $\gamma$-butyrolactone 38. Ohfune and colleagues applied the Au-catalyzed intramolecular lactonization into the allene system 37, which is a useful substrate for gold catalysis (Figure 14) [96]. Interestingly, $\gamma$-butyrolactone 38 was obtained regio- and diastereoselectively via 5-endo-dig cyclization in the presence of bulky TBS at the allenic terminal carbon.

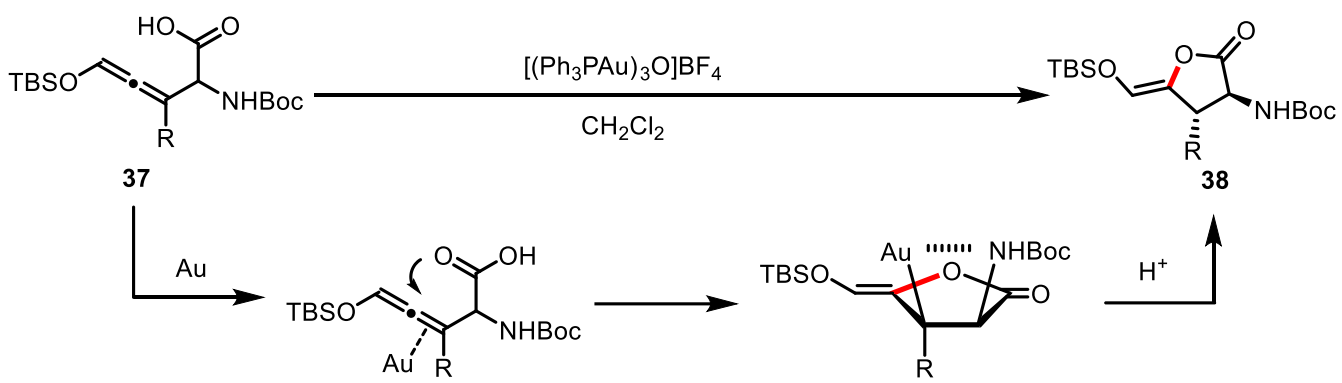

Figure 14. Gold-catalyzed lactonization of allene system.

\subsubsection{Photoredox-Catalyzed Lactonization}

Photoredox catalysis through single-electron transfer (SET) has attracted significant attention in the community of organic chemistry. Not surprisingly, the application of photoredox catalysis to the ring formation reaction, including $\gamma$-butyrolactone synthesis, has been intensively explored. As shown in Table 3, several synthetic approaches have been reported to provide 5,5-disubstituted $\gamma$-butyrolactone.

Table 3. Radical precursors in photoredox-catalyzed $\gamma$-butyrolactone synthesis.

\begin{tabular}{ccccc}
\hline Entry & $\mathbf{R}$ & $\mathbf{R}-\mathbf{R P}$ & $\mathbf{P C}$ & Ref \\
\hline 1 & $\mathrm{Aryl}$ & $\mathrm{ArN}_{2}{ }^{+} \mathrm{BF}_{4}{ }^{-}$ & $\mathrm{Ru}(\mathrm{bpy})_{3}(\mathrm{PF} 6)_{2}$ & {$[97]$} \\
2 & $\mathrm{CF}_{3}$ & $\mathrm{Umemoto}^{\prime}$ s reagent & $\mathrm{Ru}(\mathrm{bpy})_{3}(\mathrm{PF} 6)_{2}$ & {$[98]$} \\
3 & $\mathrm{Alkyl}$ & $\mathrm{NHP}$ ester & $\mathrm{Ir}(\mathrm{ppy})_{2}(\mathrm{dtbbpy}) \mathrm{PF}_{6}$ & {$[99]$} \\
\hline
\end{tabular}

$\overline{\mathrm{C}}=$ photocatalyst, $\mathrm{RP}=$ radical precursors .

Photoredox-catalyzed $\gamma$-butyrolactone synthesis generally starts with radical generation through the reduction of radical precursors 39 (e.g., diazonium salt, $N$-hydroxylphthalimide ester, etc.) by the oxidative quenching of the excited state of the photocatalyst (PC *). The in situ-generated radical $\mathbf{4 0}$ adds to the alkene of $\mathbf{4 1}$ to produce intermediate $\mathbf{4 2}$, which is transformed to carbocation $\mathbf{4 3}$ through single-electron transfer (SET) with an oxidized photocatalyst $\left(\mathrm{PC}^{+}\right)$. Nucleophilic attack of the carboxylic acid results in the $\gamma$-butyrolactone 44 (Figure 15). Aryl diazonium salts (Entry 1) [97], Umemoto's reagent (Entry 2) [98], Nhydroxylphthalimide ester (Entry 3) [99], and $\alpha$-bromo ester [100] were used in these reactions. 


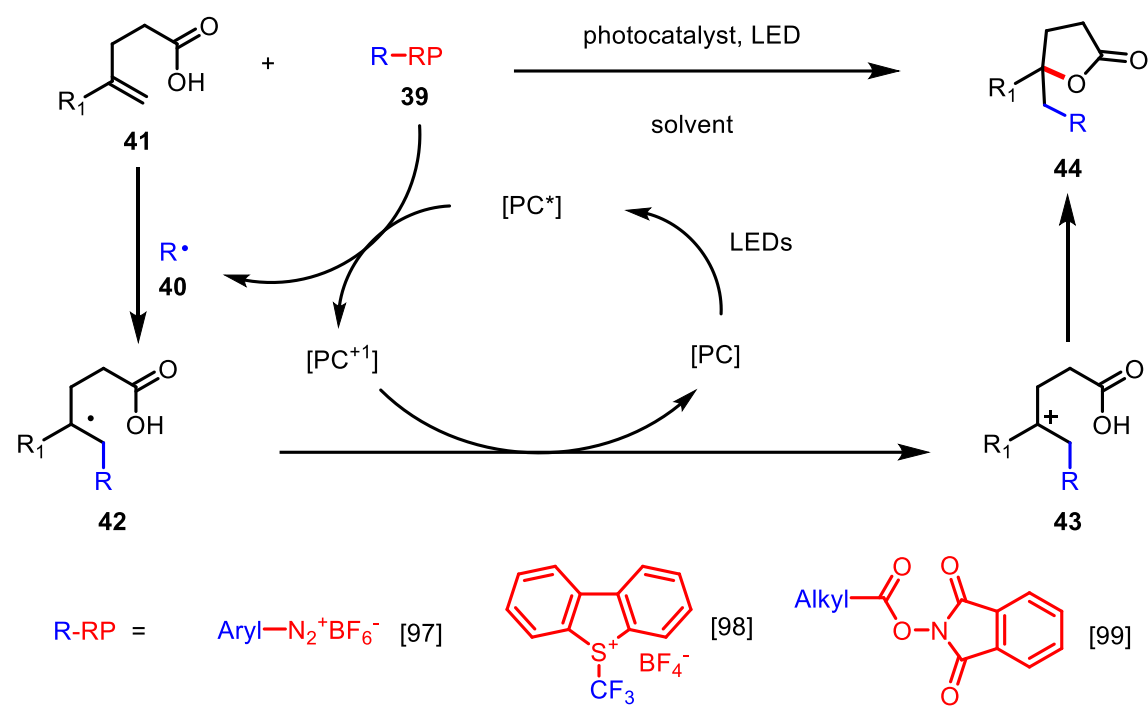

Figure 15. Photoredox-catalyzed $\gamma$-butyrolactone synthesis.

\subsection{Synthesis of $\gamma$-Butyrolactone via $\mathrm{C} 4-\mathrm{C} 5$ and $\mathrm{C} 2-\mathrm{O} 1$ Bonds Formation}

Connecting the $\mathrm{C} 4-\mathrm{C} 5$ bond in [3 +2$]$ annulation-type $\gamma$-butyrolactone formation is one of the most promising routes. Retrosynthetically, the disconnection of the C4-C5 and $\mathrm{C} 2-\mathrm{O} 1$ bonds gives $\mathrm{a}^{3}$ and $\mathrm{a}^{2}$ synthons; thus, this mismatched relationship should be overcome through a certain umpolung reaction.

\subsubsection{Transition-Metal Catalyzed C-C Bond Coupling}

Krische et al. applied their transfer hydrogenative C-C bond coupling chemistry to the $\gamma$-butyrolactone syntheses. In 2012, they reported that the iridium-catalyzed carbonyl 2-(alkoxycarbonyl)allylation between various primary alcohols $\mathbf{4 5}$ and acrylic ester $\mathbf{4 6}$ afforded $\gamma$-substituted $\alpha$-exo-methylene- $\gamma$-butyrolactone 47 with high enantioselectivity (Figure 16) [101]. As shown in the mechanism, this transformation involves an $\mathrm{a}^{3}-\mathrm{d}^{3}$ umpolung process regarding the $\beta$-position of the acrylate counterpart 46 , which normally acts as an electrophile during C-C bond-forming reactions [102].

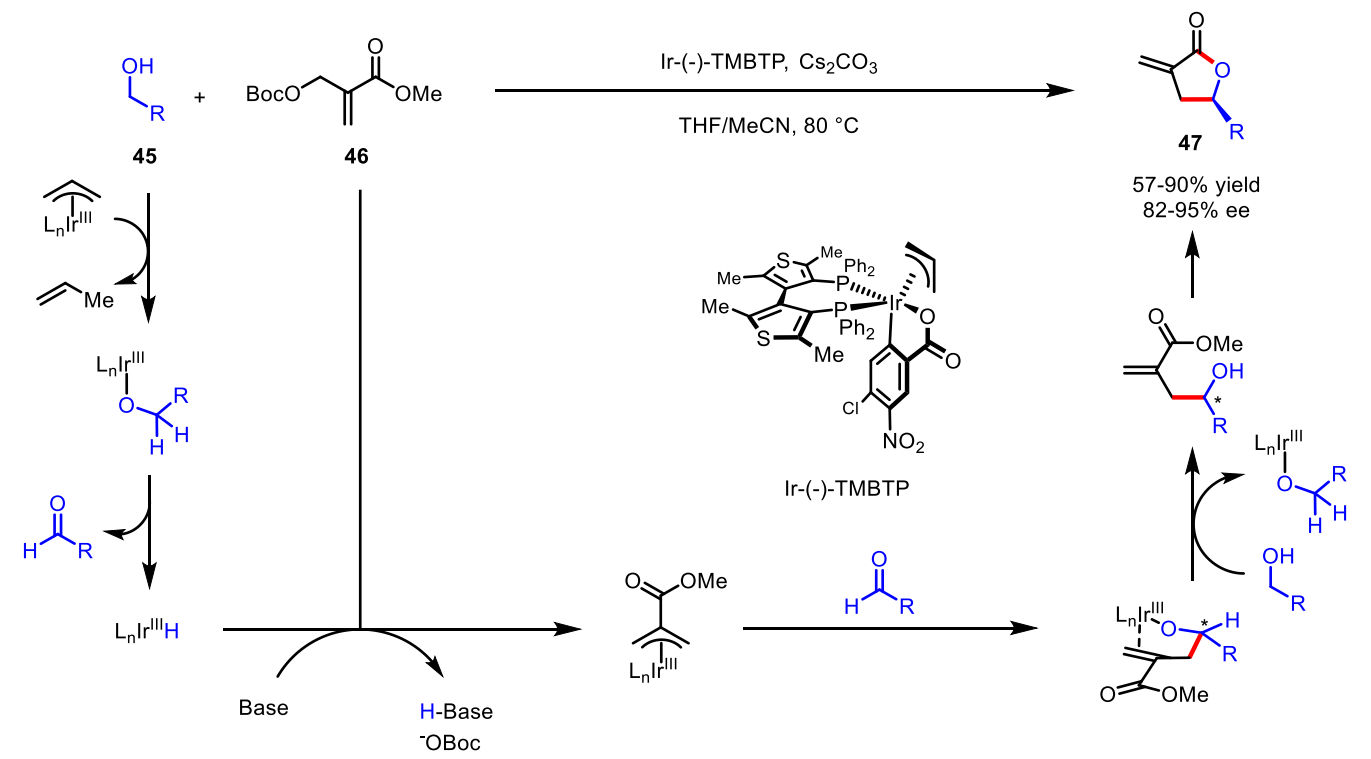

Figure 16. Asymmetric synthesis of $\alpha$-exo-methylene- $\gamma$-butyrolactone via iridium-catalyzed 2(alkoxycarbonyl)allylation. 
In the C-C bond constructing catalytic transfer hydrogenation, a secondary alcohol was not a suitable partner of acrylates because of the low susceptibility to the nucleophilic attack [103] of the $\pi$-allyl complex derived from the acrylates. Just a year after their first report, Krische and colleagues also revealed that ruthenium(0)-catalyzed hydrohydroxyalkylation of acrylates with vicinal diols or their oxidized congeners could provide a series of $\gamma$-butyrolactones, including spiro- $\gamma$-butyrolactones (Figure 17a), polysubstituted 2,3'-spirooxindole- $\gamma$-butyrolactones (Figure 17b), and $\alpha$-exo-methylene- $\gamma$-butyrolactones (Figure 17c) [104]. As illustrated in Figure 17d, 1,2-diol 48 and its highly oxidized congeners 49 and 50 were transformed into the same outcome 51, indicating that this transformation proceeds in a redox level-independent manner.

a.<smiles>[R]C(O)C(O)O</smiles><smiles>C=CC(=O)O[Na]</smiles>

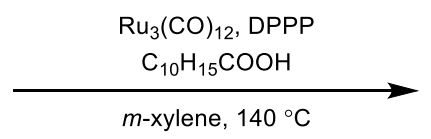<smiles>O=C1CCC2(OC1)[C@H]1CCC[C@H]2C1=O</smiles>

b.<smiles></smiles><smiles>[R]C([R3])=C([R])C(=O)OC</smiles>

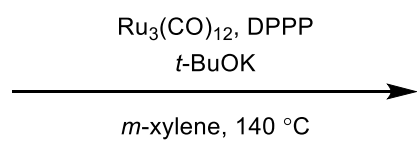

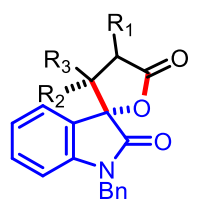

c.<smiles>[R]C(O)C([R])O</smiles>

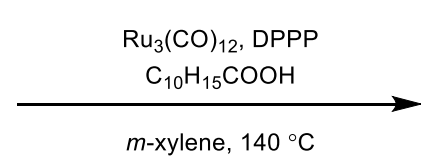<smiles>[R]C(=O)C1([R])CC(=C)C(=O)O1</smiles>

d.<smiles>OC(O)C(O)P</smiles>
48 or<smiles>O=C(c1ccccc1)C(O)c1ccccc1</smiles>
49 or<smiles>CC=C(C(=O)c1ccccc1)c1ccccc1</smiles>
50

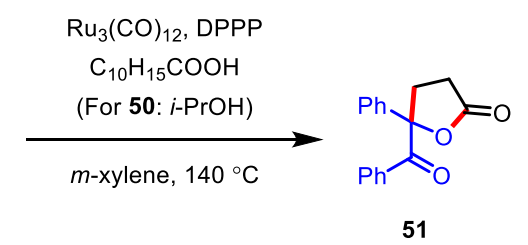

Figure 17. Syntheses of $\gamma$-butyrolactones via ruthenium-catalyzed hydrohydroxyalkylation. (a) Syntheses of spiro- $\gamma$-butyrolactones from diols and methyl acrylate; (b) Syntheses of polysubstituted 2,3'-spirooxindole- $\gamma$-butyrolactones from $N$-benzyl-3-hydroxyoxindole and acrylic esters; (c) Syntheses of $\alpha$-exo-methylene- $\gamma$-butyrolactones from hydroxyl-substituted methacrylate and diols; (d) Redox level-independent formation of $\mathbf{5 1 .}$

The asymmetric synthesis of $\alpha$-exo-methylene $\gamma$-butyrolactones was developed by Zhang and colleagues in 2015 (Figure 18) [105]. This methodology utilized an enantioselective chromium-catalyzed carbonyl 2-(alkoxycarbonyl)allylation of a wide range of aldehydes. To achieve superior enantioselectivity, the $\mathrm{C} 2$ symmetric bisoxazoline ligand was essential. Rigidification of Guiry's tridentate ligand [106] provided a new ligand 52, which resulted in excellent enantiomeric excess of up to $99 \%$. Similar to the previous methods $[101,104]$, the inherent positive character of the acrylate $\beta$-position was inverted via the cobalt-assisted generation of allyl-chromium species 53 . To demonstrate the synthetic utility, the total synthesis of an antitumor and antimicrobial natural product, (+)-methylenolactocin 54, was successfully conducted with a 53\% overall yield over three steps and $92 \%$ ee. (Figure 18, bottom). 

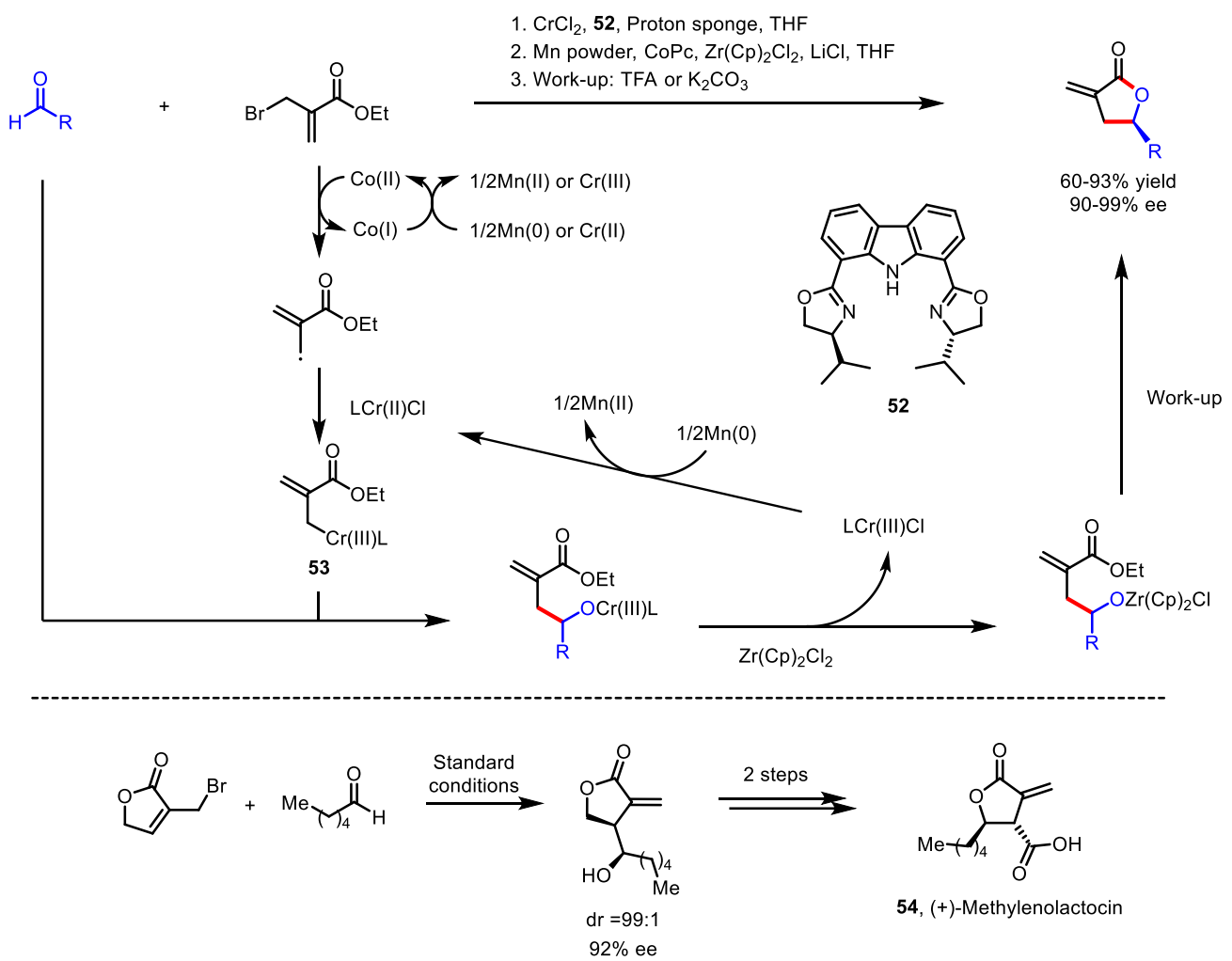

Figure 18. Asymmetric synthesis of $\alpha$-exo-methylene $\gamma$-butyrolactone via chromium-catalyzed 2-(alkoxycarbonyl)allylation and lactonization and total synthesis of (+)-methylenolactocin.

Spirooxindoles [107] and $\alpha$-exo-methylene- $\gamma$-butyrolactones [12,108], biologically relevant structural motifs, have received attention from medicinal chemists. In this regard, the fusion of two scaffolds would be a promising strategy for securing biologically active scaffolds. In 2013, the first asymmetric synthesis of 2,3'-spirooxindole- $\alpha$-exo-methylene $\gamma$-butyrolactone 57 via the indium(III)-catalyzed allylation of isatins 55 and $\beta$-amido allylstannanes $\mathbf{5 6}$ was reported (Figure 19) $[107,109]$. The amide NH proton of allylstannanes was essential for enhancing enantioselectivity as well as complete conversion by engaging in six-coordinated indium complex 58 with tridentate ligand 59, thereby inducing 56 to approach from $R e$-face [109]. The resulting acyclic 2-oxindoles 60 was cyclized under acidic conditions to afford the desired lactone $\mathbf{5 7}$ with complete stereochemistry retention.

\subsubsection{NHC-Catalyzed C-C Bond Coupling}

A chiral $\mathrm{N}$-heterocyclic carbene (NHC) has played an important role in making a homoenolate nucleophile from enals through the $\mathrm{a}^{3}-\mathrm{d}^{3}$ umpolung reaction [110]; thus, it has been widely used in the optically active $\gamma$-butyrolactone synthesis via [3+2] annulation. Over the last decade, this strategy has been employed to construct a $2,3^{\prime}$ spirooxindole- $\gamma$ butyrolactone system.

In 2011, Ye and colleagues discovered the first enantioselective NHC-catalyzed synthesis of spirooxindole- $\gamma$-lactone with isatin and an enal as substrates (Figure 20a) [111]. A chiral NHC $\mathbf{6 1}$ derived from L-pyroglutamic acid displayed the best result, affording the desired spirolactone up to $99 \%$ ee. A proximal hydroxy group in $\mathbf{6 1}$ was crucial to obtain the lactone with an excellent yield and enantioselectivity because the hydrogen bonding between the carbonyl group of isatin and the catalyst hydroxy group may guide the direction of the isatin approach and enhance its reactivity. 


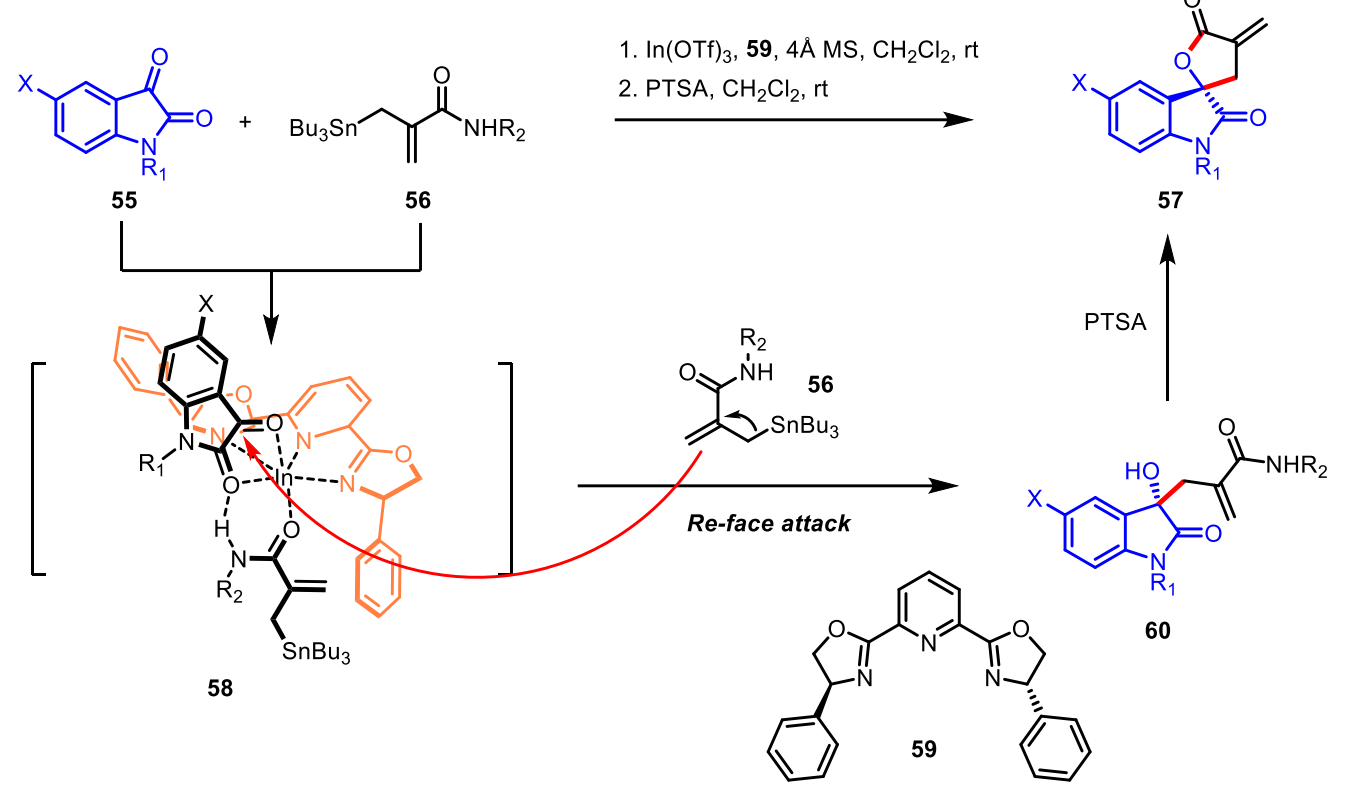

Figure 19. Asymmetric synthesis of $2,3^{\prime}$-spirooxindole- $\alpha$-exo-methylene $\gamma$-butyrolactone via indiumcatalyzed amide allylation and lactonization.

A year later, a similar NHC-catalyzed transformation was carried out in the presence of lithium chloride as an external activator. Scheidt and colleagues revealed that the addition of two equivalents of $\mathrm{LiCl}$ to the reaction gave the beneficial effect of creating an organized transition state with $\mathbf{6 2}$, which offered excellent enantioselectivity, similar to the role of the internal hydroxy group of $\mathbf{6 1}$ in the previous method (Figure 20b) [112].

In 2015, it was independently disclosed by Chi (Figure 20c) [113] and Yao (Figure 20d) [114] that aliphatic acids could participate in the NHC-catalyzed spiro- $\gamma$-lactone construction instead of the aldehyde substrates. The key to this modification was the in situ pre-activation of carboxylic acid by various peptide coupling reagents, which enabled the formation of a common NHC-coupled homoenolate intermediate.

Finally, $\mathrm{Xu}$ and colleagues reported that the saturated aryl ester 64 was also able to engage in this type of NHC-catalyzed asymmetric annulation with catalytic amount of 1-hydroxybenzotriazole (HOBt) (Figure 20e) [115]. After the experimental studies, it was revealed that $\mathrm{HOBt}$ had a dual role: activation of the ester for the next substitution by the chiral NHC, and the stabilization of the effective transition state via hydrogen bonding.

A chiral NHC led to significant advances in dynamic kinetic resolution (DKR)mediated asymmetric transformation. In 2015, Johnson and colleagues developed the first intermolecular DKR between $\alpha, \beta$-unsaturated aldehydes and racemic $\beta$-halo- $\alpha$-keto esters 65 , which installed three stereocenters during the single bond-forming process (Figure 21) [116]. Using this strategy, they obtained 3,4,4-trisubstituted $\gamma$-butyrolactones 66 with three contiguous stereocenters in a single operation, with excellent enantioselectivity (up to $98 \%$ ee). 
a.

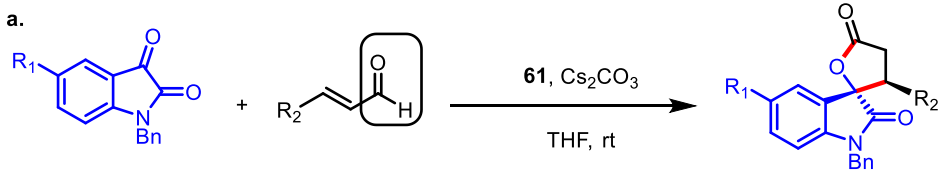

b.<smiles>[R3]CC1=C(C)CCCC1=O</smiles><smiles>[B-][N+]1(c2ccccc2)CN2C(=N1)CC[C@@H]2C(O)(c1ccccc1)c1cc(C(F)(F)F)cc(C(F)(F)F)c1</smiles><smiles>[R]c1ccc2c(c1)C(=O)C(=O)N2</smiles><smiles>[R]CC(=O)CCCCC</smiles>

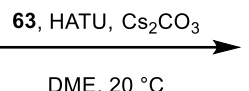<smiles>[R]c1ccc2c(c1)[C@]1(OC(=O)CC1[R])C(=O)N2</smiles><smiles></smiles>

62

d.<smiles>O=C1Nc2ccc(Br)cc2C1=O</smiles><smiles>CCCCCCC(=O)O</smiles>

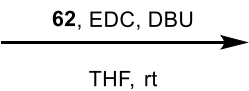<smiles>[R]c1ccc2c(c1)[C@@]1(CCC(=O)O1)C(=O)N2</smiles><smiles>[R]c1ccc2c(c1)C(=O)C(=O)N2</smiles><smiles>[R]CC(=O)OC1CC2CCC1C2</smiles>

63, $\mathrm{Cs}_{2} \mathrm{CO}_{3}, \mathrm{HOBt}, 4 \AA \mathrm{MS}$

(1) THF, rt $\mathrm{Ar}=4-\mathrm{NO}_{2} \mathrm{C}_{6} \mathrm{H}_{4}$<smiles>[R]C1N[C@@]2(OC(=O)CC2[R])OC1[R2]</smiles>

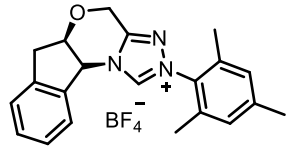

63

Figure 20. Asymmetric syntheses of 2,3'-spirooxindole- $\gamma$-butyrolactone via NHC-catalyzed homoenolate annulation. (a,b) NHC-catalyzed 2,3'-spirooxindole- $\gamma$-butyrolactone formation from enals; (c,d) NHCcatalyzed 2,3'-spirooxindole- $\gamma$-butyrolactone formation from carboxylic acids; (e) NHC-catalyzed 2,3'spirooxindole- $\gamma$-butyrolactone formation from aryl esters.

\subsubsection{Photoredox-Catalyzed C-C Bond Coupling}

Photoredox catalysis achieves the cutting-edge evolution in the $\mathrm{C}-\mathrm{H}$ bond activation chemistry; thus, it enables not only mild, economical, and environmentally friendly chemical reactions, but also the discovery of unprecedented reactivity of chemical bonds [117]. In 2015, MacMillan's seminal work demonstrated that the $\alpha-\mathrm{C}-\mathrm{H}$ bond of alcohols could by selectively activated in the presence of allylic, benzylic, $\alpha-\mathrm{C}=\mathrm{O}$, and $\alpha$-ether $\mathrm{C}-\mathrm{H}$ bonds. In addition, the corresponding $\alpha$-hydroxyl radical participated in the formation of the $\gamma$-lactones with methyl acrylate (Figure 22) [118]. The $\mathrm{C}-\mathrm{H}$ bond-weakening, assisted by hydrogen bond, gave rise to the unique selectivity, which was supported by tetra- $n$ butylammonium phosphate as a catalytic H-bond acceptor. The versatility of this methodology was demonstrated by testing several structurally complex substrates 68-75 containing inherently activated $\mathrm{C}-\mathrm{H}$ bonds (Figure 22, bottom). 

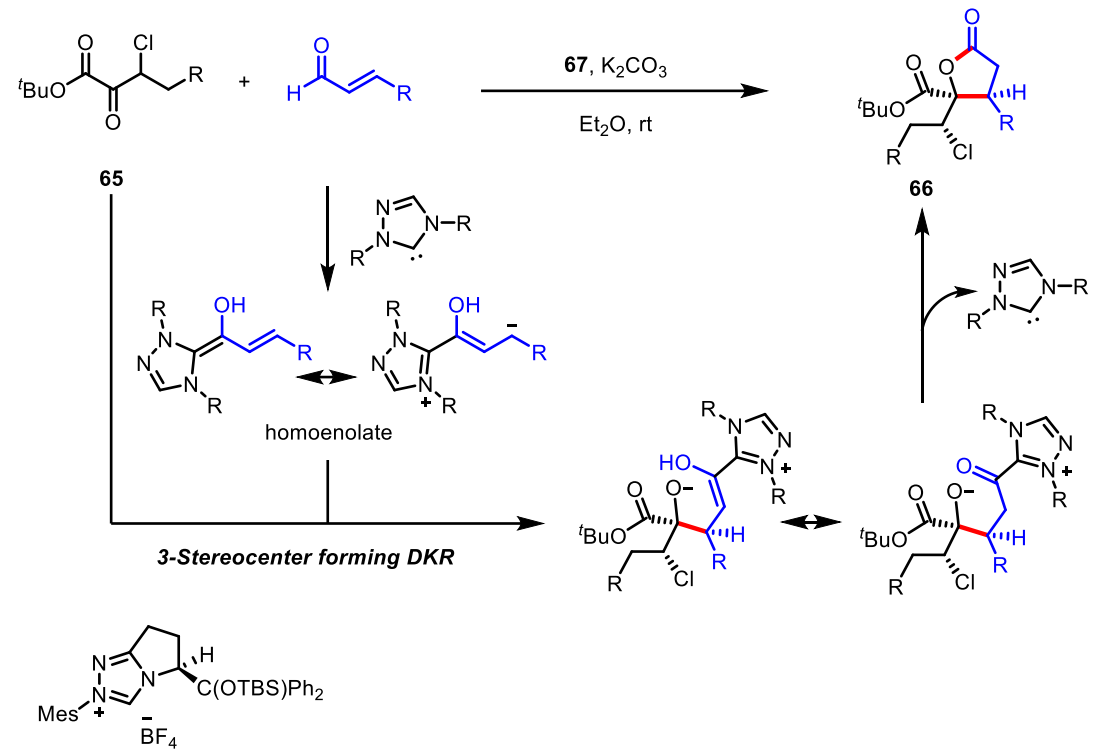

67

Figure 21. Asymmetric synthesis of 3,4,4-trisubstituted $\gamma$-butyrolactones via NHC-catalyzed dynamic kinetic resolution.
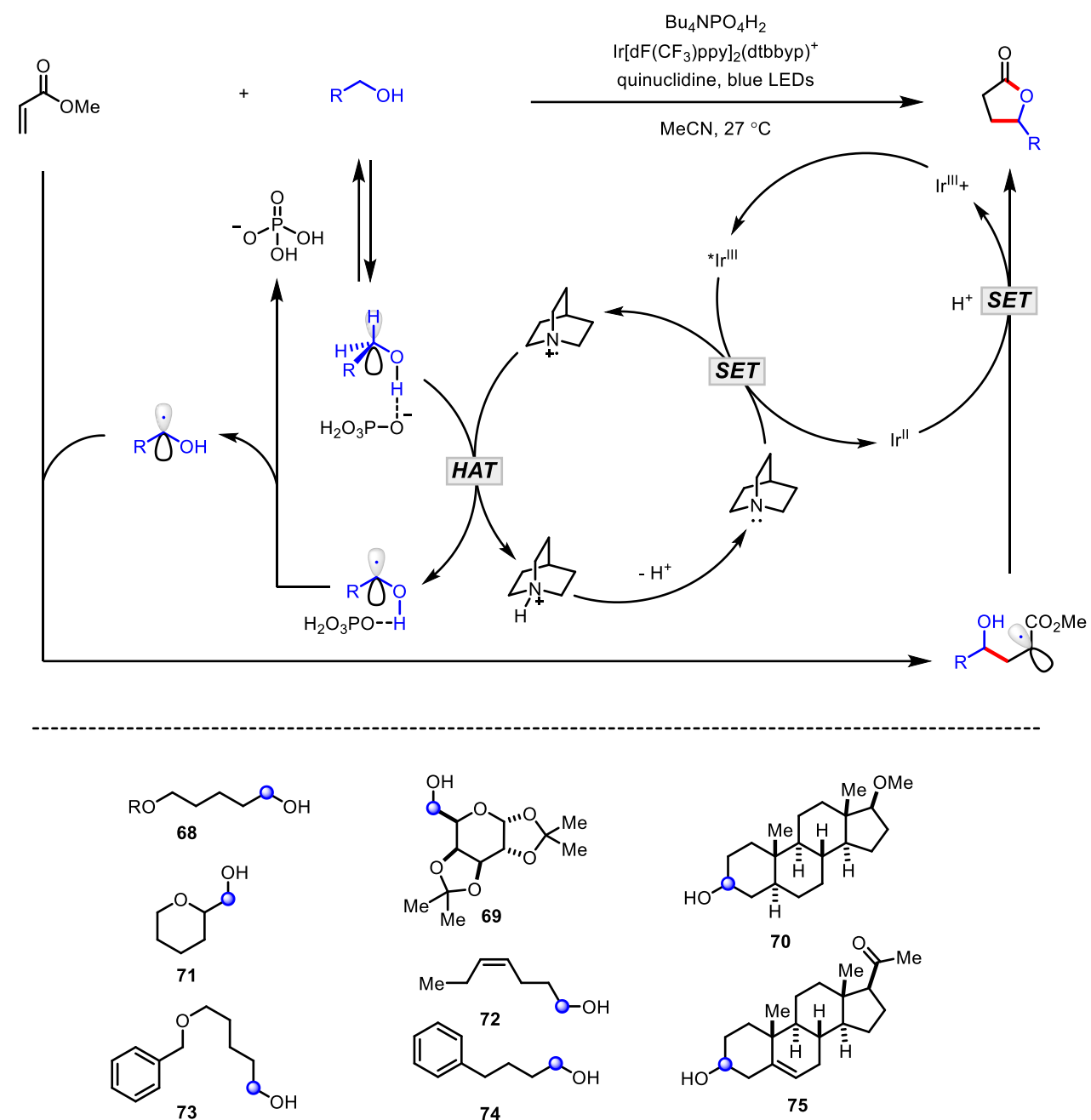

Figure 22. Synthesis of $\gamma$-butyrolactones via the alcohol-selective $\mathrm{C}-\mathrm{H}$ activation mediated by photoredox catalysis. 
Recently, the greener variant of typical photoredox catalysis, the photo-organocatalytic synthesis of this lactone has been accomplished by Kokotos and colleagues. (Figure 23) [119]. By utilizing a readily available and cheap photoinitiator, phenylglyoxalic acid $\mathbf{7 6}$ as an alternative to transition metal catalysts, a variety of primary and secondary alcohol 77 and a maleic acid diester $\mathbf{7 8}$ merged into the corresponding $\gamma$-butyrolactones $\mathbf{7 9}$ in the presence of visible light from sunlight or simple household lamps. Through extensive mechanistic studies, it was proposed that photoinduced exciplex $\mathbf{8 0}$ formation facilitates selective hydrogen atom abstraction from the secondary alcohol.

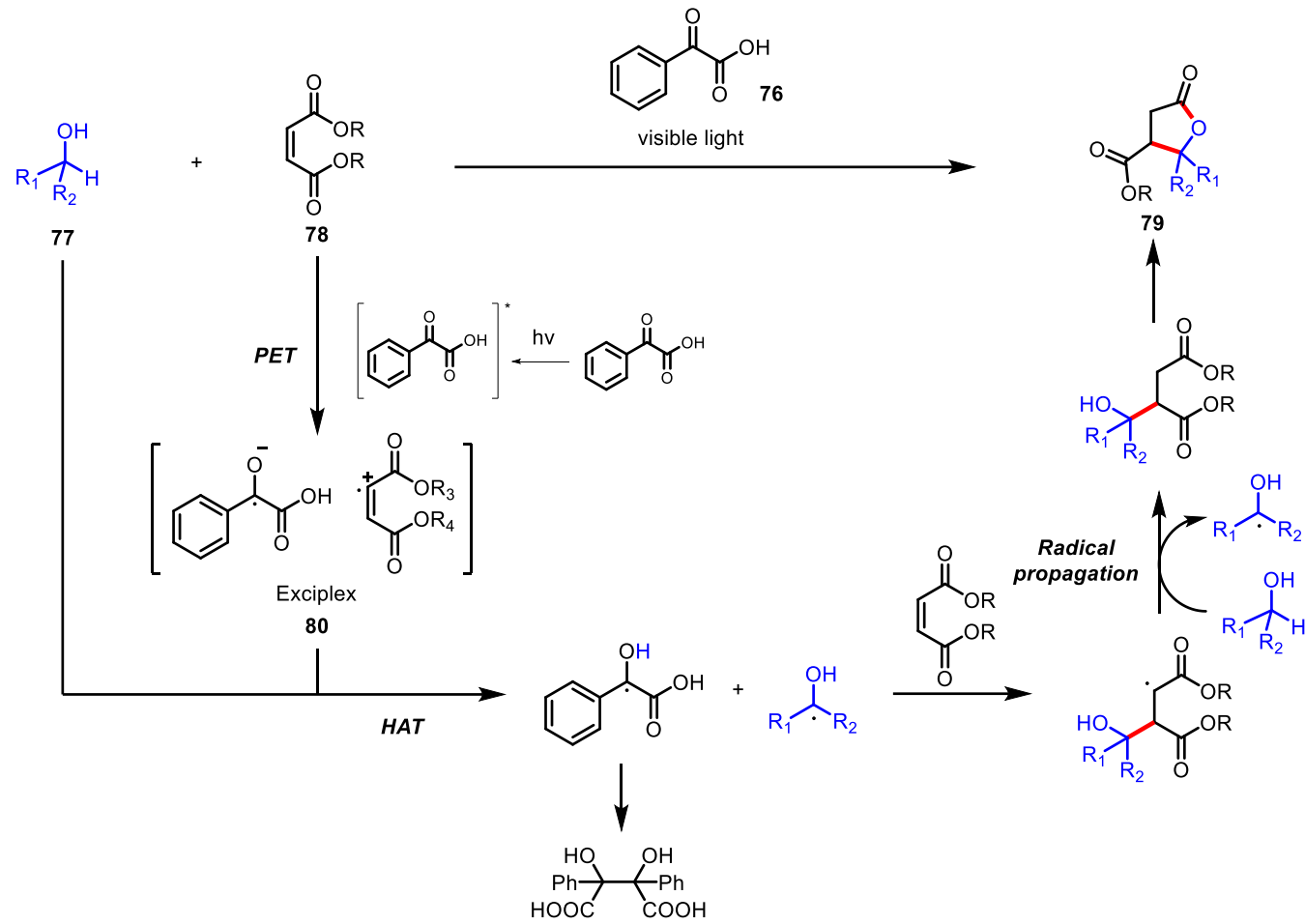

Figure 23. Synthesis of $\gamma$-butyrolactones via photoorganocatalytic $\mathrm{C}-\mathrm{H}$ activation.

\subsubsection{Miscellsious $\gamma$-Butyrolactone Formation}

Electroreduction of carbonyl compounds can convert electrophilic carbonyl compounds into nucleophilic carbanion, which is further involved in the [3+2] coupling of $\gamma$-butyrolactones. In this regard, electroreductive $C$-C coupling of $\alpha, \beta$-unsaturated carbonyl compounds with ketones or aldehydes has been known to be useful for the synthesis of $\gamma$ butyrolactones. A previous electroreductive method [120] toward lactones in the presence of trimethylsilyl chloride (TMSCl) was improved by Kise and colleagues by means of a chiral auxiliary, leading to optically active 4,5,5-trisubstituted $\gamma$-butyrolactones 83 in high diastereoselectivity (Figure 24) [121]. The reaction is initiated with two-electron transfer to a more reducible diaryl ketone $\mathbf{8 2}$. The resulting carbanion $\mathbf{8 4}$ is diastereoselectively coupled with the Michael acceptor 81. DFT calculations for the bond-forming transition states explained the reason for its $\mathrm{Si}$-face preference. 
<smiles>[R]C=CC(=O)n1c([R])c([Y8])[X]c1=O</smiles>

$\mathrm{X}=\mathrm{NMe}$ or $\mathrm{O}$

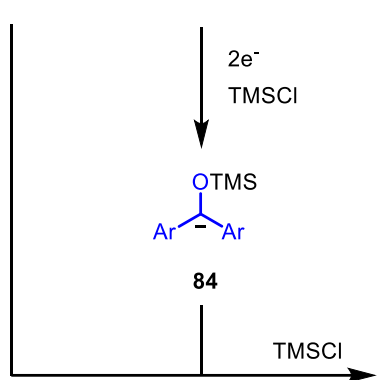

1. $\mathrm{Bu}_{4} \mathrm{NClO}_{4}, \mathrm{Et}_{4} \mathrm{NOTs}$, TMSCI, TEA

$(+) \mathrm{Pt} /(-) \mathrm{Pb}, \mathrm{THF}, 100 \mathrm{~mA}, \mathrm{rt}$ 2. TBAF, THF, rt

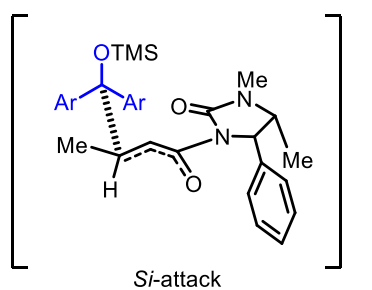<smiles>[R]C1CC(=O)OC1([Al])[AlH]</smiles>

83

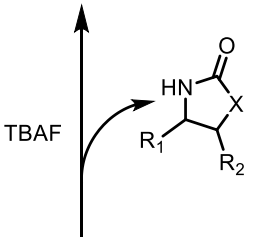

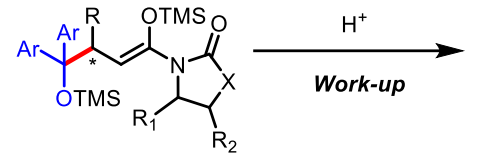

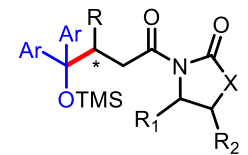

Figure 24. Asymmetric synthesis of 4,5,5-trisubstituted- $\gamma$-butyrolactones via electroreductive C-C bond coupling.

The synthesis of 3,3'-spirooxindole- $\gamma$-butyrolactones, another isomeric form of the spirooxindole- $\gamma$-lactone motif, has attracted less attention, but it is still valuable when it comes to the longstanding need to secure a structurally diverse chemical library in the drug discovery field. In 2017, Du and colleagues revealed that the peptide coupling reagent (PCR)-assisted $\beta$-functionalization of indoline-2-one aliphatic acids 85 could produce the desired spirofused $\gamma$-lactone 86 and 87 via [3 +2$]$ coupling with electrophilic carbonyl substrates; isatins $\mathbf{8 8}$ or trifluoromethyl ketones $\mathbf{8 9}$ (Figure 25) [122]. After the intensive screening of the reaction conditions, it was found that the optimal PCR was HATU for isatin substrates and CDI for trifluoromethyl ketone substrates.

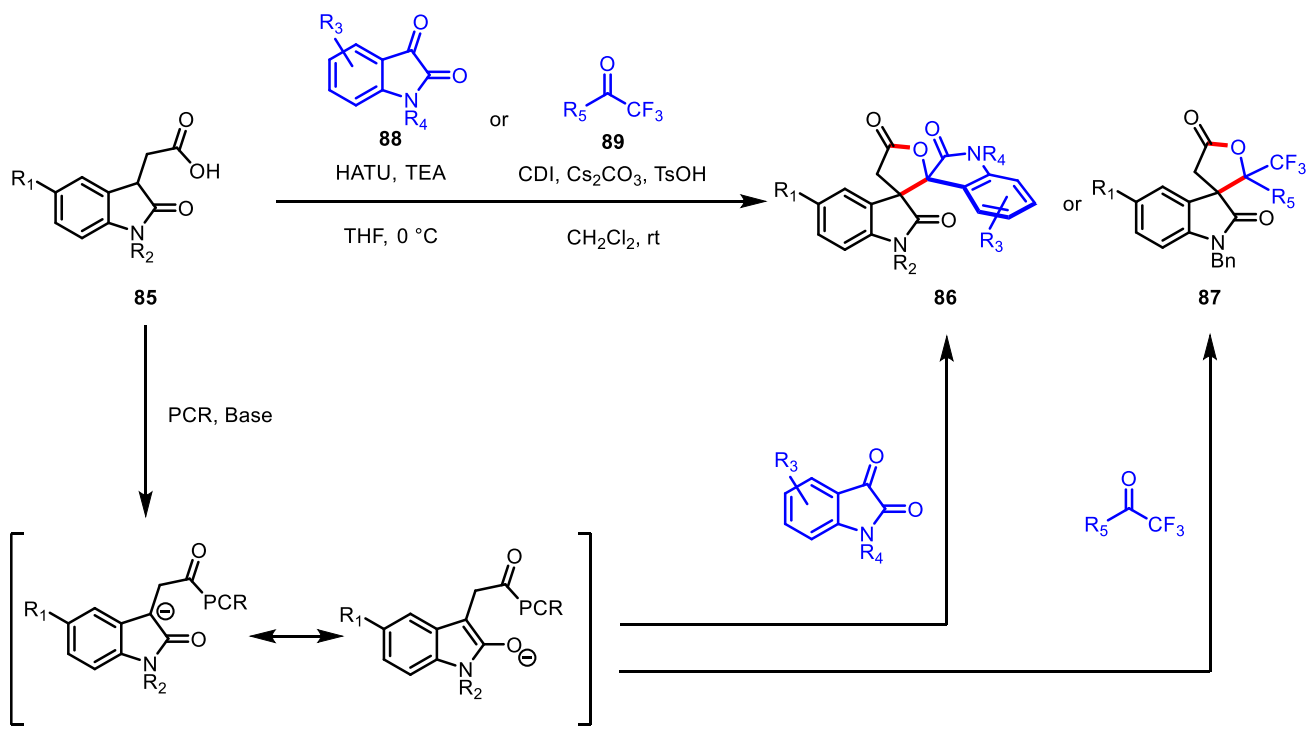

Figure 25. Synthesis of $3,3^{\prime}$-spirooxindole- $\gamma$-butyrolactones via peptide coupling reagent-assisted lactonization.

In 2017, a one-pot multicomponent reaction was exploited to construct enantiomerically pure 4,5-disubstituted $\gamma$-butyrolactones 93 by Bhat and colleagues. (Figure 26) [123]. Their strategy was the organocatalyzed Knoevenagel condensation/Michael addition/ decarboxylative lactonization cascade utilizing cheap and readily accessible starting materials such as Meldrum's acid 90, aldehydes 91, hydroxyketones $\mathbf{9 2}$, and the chiral cinchona 
catalyst $\mathbf{9 4}$. Enamine (Z)-95, which has a chiral environment induced by $\mathbf{9 4}$, is subjected to asymmetric 1,4-addition with the Knoevenagel condensation adduct 96 to afford 97 bearing two contiguous stereogenic centers. This precisely designed three-component reaction was able to avoid possible side reactions such as aldol condensation products between 91 and 92.

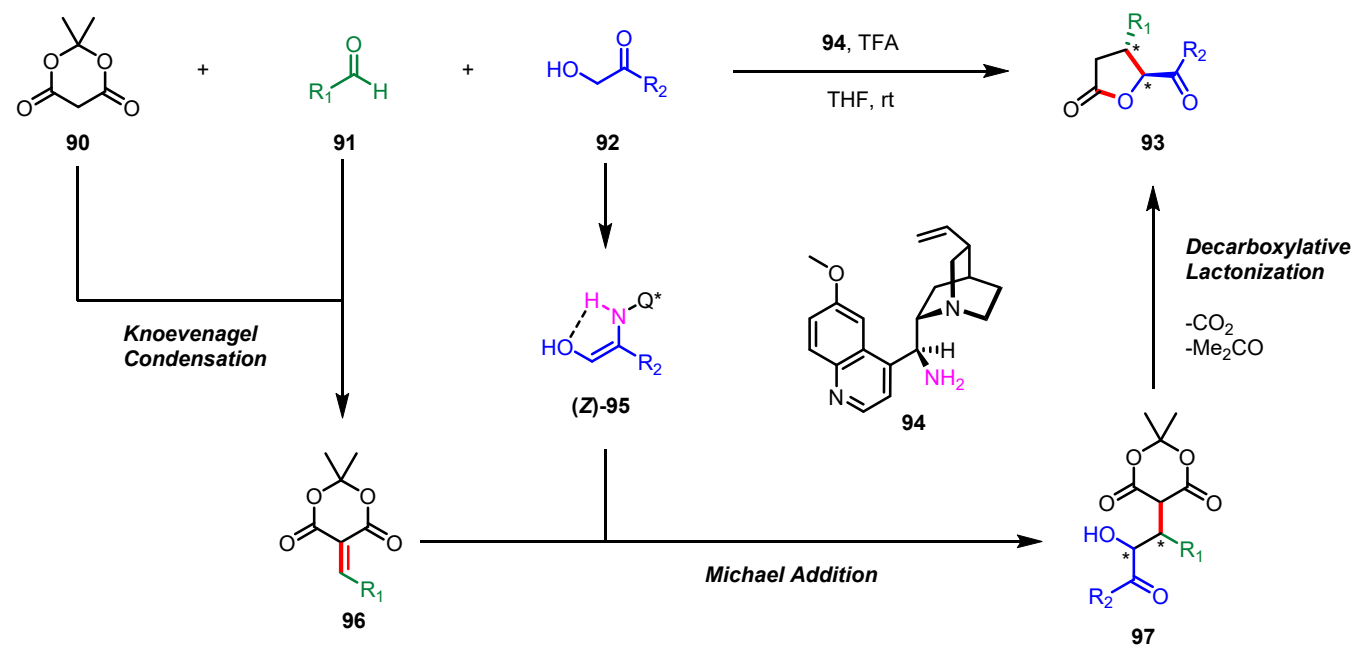

Figure 26. Asymmetric synthesis of 4,5-disubstituted- $\gamma$-butyrolactones via organocatalyzed threecomponent coupling.

\subsection{Synthesis of $\gamma$-Butyrolactones via C3-C4 and C2-O1 Bond Formation}

Connecting the $\mathrm{C} 3-\mathrm{C} 4$ bond in $[3+2]$ annulation-type $\gamma$-butyrolactone formation has been less investigated than that of C4-C5 bond formation. Nevertheless, the development of this synthetic route is still significant, in that securing diverse synthetic tools has always been beneficial to organic chemists, particularly for complex natural product synthesis. Retrosynthetically, the disconnection of the C3-C4 and C2-O1 bonds gives $\mathrm{d}^{3}$ and $\mathrm{d}^{2}$ synthons; thus, this mismatched relationship should be overcome through a certain umpolung reaction.

A borrowing hydrogen methodology, also known as hydrogen autotransfer, is a subclass of a wide range of transfer hydrogenation chemistry similar to the aforementioned transfer hydrogenative C-C bond coupling [124,125]. Beller and colleagues reported that ruthenium $(\mathrm{Ru})$ pincer catalyst $\mathbf{1 0 0}$ promoted $\gamma$-butyrolactone synthesis from 1,2-diols 98 and malonates 99 (Figure 27) [126]. Catalyst 100 temporarily abstracts hydrogen from 1,2diols to give the corresponding $\alpha$-hydroxyketone 101, which can act as an electrophile. This step belongs to a polarity inversion process at the $C 3$ position of the resulting $\gamma$-lactones. Whereas the above-mentioned Ru-catalyzed spirolactonization consequentially delivers alcohol C-H functionalization type products (see Figure 17), this Ru-catalysis proceeds through a type of alcohol substitution, which offers monocyclic lactones. 


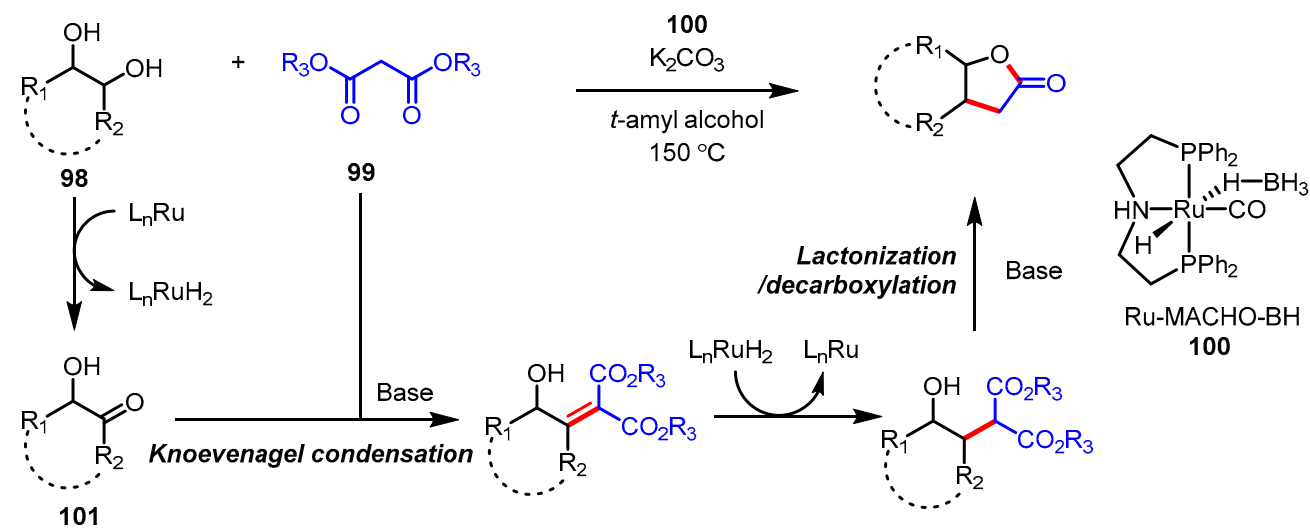

Figure 27. Synthesis of $\gamma$-butyrolactones via ruthenium pincer-catalyzed hydrogen autotransfer.

An epoxide is a useful three-atom building block in the [3 + 2] annulation strategy because of its susceptibility to the attack of suitable carbon nucleophiles such as ester enolates. In 2017, ketene silyl acetal 102 was applied as the effective enolate equivalent to constructing the lactone via regioselective epoxide opening followed by lactonization (Figure 28) [127]. Additionally, an ionic liquid system composed of a mixture of 1,3-dimethylimidazolium fluoride $([\mathrm{Dmim}] \mathrm{F})$ and 1-butylimidazolium tetrafluoroborate $\left([\mathrm{Hbim}] \mathrm{BF}_{4}\right)$ was utilized to achieve the desired transformation. The catalytic amount of [Dmim]F acted as a Si-O bond activator and $[\mathrm{Hbim}] \mathrm{BF}_{4}$ served as the solvent providing acidic media. This ionic liquid mixture was able to be reused up to three times, which is valuable for the contribution toward green chemistry.

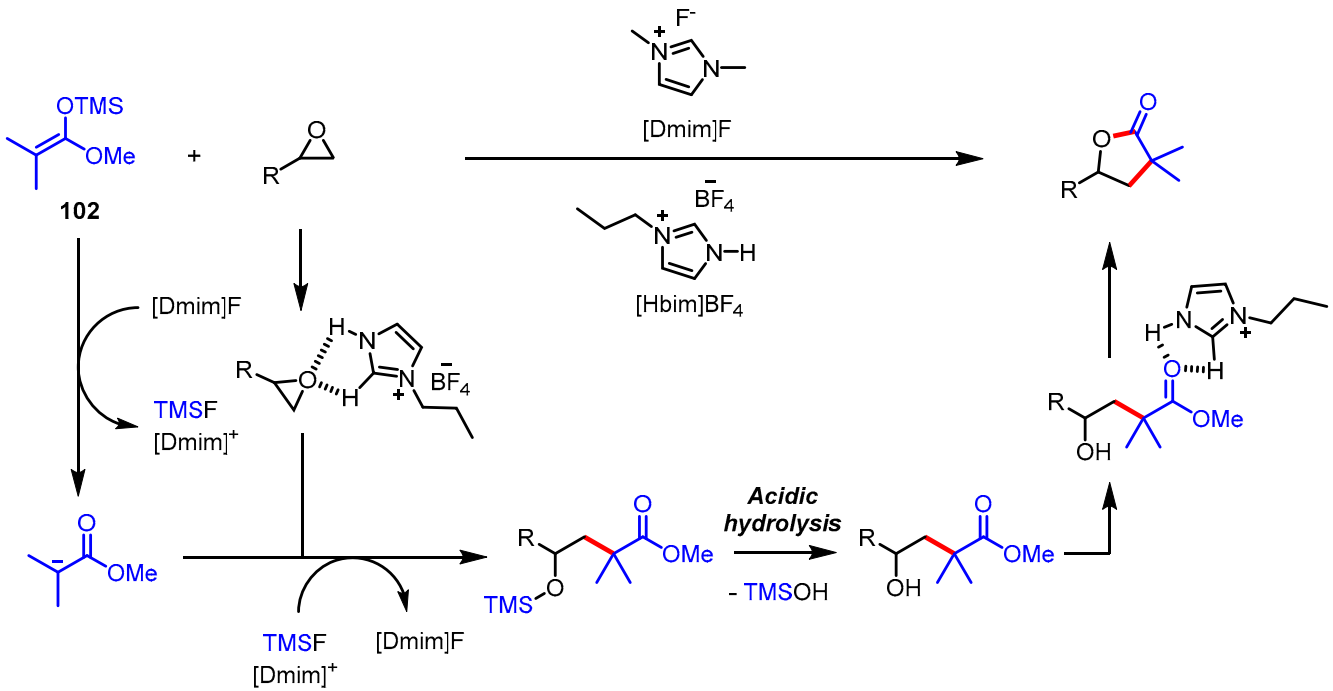

Figure 28. Synthesis of $\gamma$-butyrolactones via ionic liquid-assisted epoxide opening and lactonization.

\subsection{Synthesis of Butyrolactone via C3-C4 and C5-O1 Bonds Formation}

There are a few examples of this synthetic approach through the formation of $\mathrm{C} 3-\mathrm{C} 4$ and C5-O1 bonds during 2010 to 2020. Mostly, the single-electron transfer pathway is involved in the $\mathrm{C} 3-\mathrm{C} 4$ and $\mathrm{C} 5-\mathrm{O} 1$ bond formation approaches. First, photoredox catalysis was applied with alkenes and suitable counterparts such as $\alpha, \beta$-unsaturated acid [128], oxime acid [129], or haloacetic acid [130]. Second, a metal oxidant-mediated transformation of glycals to $\gamma$-butyrolactones was reported [131]. Third, the copper-catalyzed-cyclopropanol ring-opening cross-coupling reaction was utilized to synthesize $\gamma$-butyrolactones containing quaternary carbon centers [132]. 


\subsubsection{Polar Radical Crossover Cycloaddition (PRCC)}

Polar radical crossover cycloaddition (PRCC) has been utilized in the construction of various saturated heterocycles, including tetrahydrofurans [133], $\gamma$-lactams, and pyrrolidines [134]. The co-catalyst of Fukuzumi acridinium single-electron photooxidant and a redox-active hydrogen atom donor is a key mediator of PRCC through photoredox catalysis. Nicewicz and colleagues extended the PRCC approach to the synthesis of $\gamma$ butyrolactones [128]. First, the oxidizable alkenes $\mathbf{1 0 3}$ and $\alpha, \beta$-unsaturated acids $\mathbf{1 0 5}$ as nucleophiles forged $\gamma$-butyrolactones $\mathbf{1 0 7}$ under photoredox catalysis. As depicted in Figure 29, an electrophilic alkene cation radical $\mathbf{1 0 4}$ is formed by the excited acridiniummediated single-electron oxidation followed by the generation of the radical intermediate 106 through the addition of carboxylic acid $\mathbf{1 0 5}$ to the alkene cation radical. 5-exo-trig radical cyclization and hydrogen atom transfer with thiophenol provided the desired $\gamma$-butyrolactones. Alternatively, $\alpha$-amino- $\gamma$-butyrolactones $\mathbf{1 1 0}$ have also been synthesized by the PRCC method using oxidizable alkenes 108 and $O$-benzyloxime acids 109, which correspond to $\alpha, \beta$-unsaturated acids 105 (Figure 30) [129].

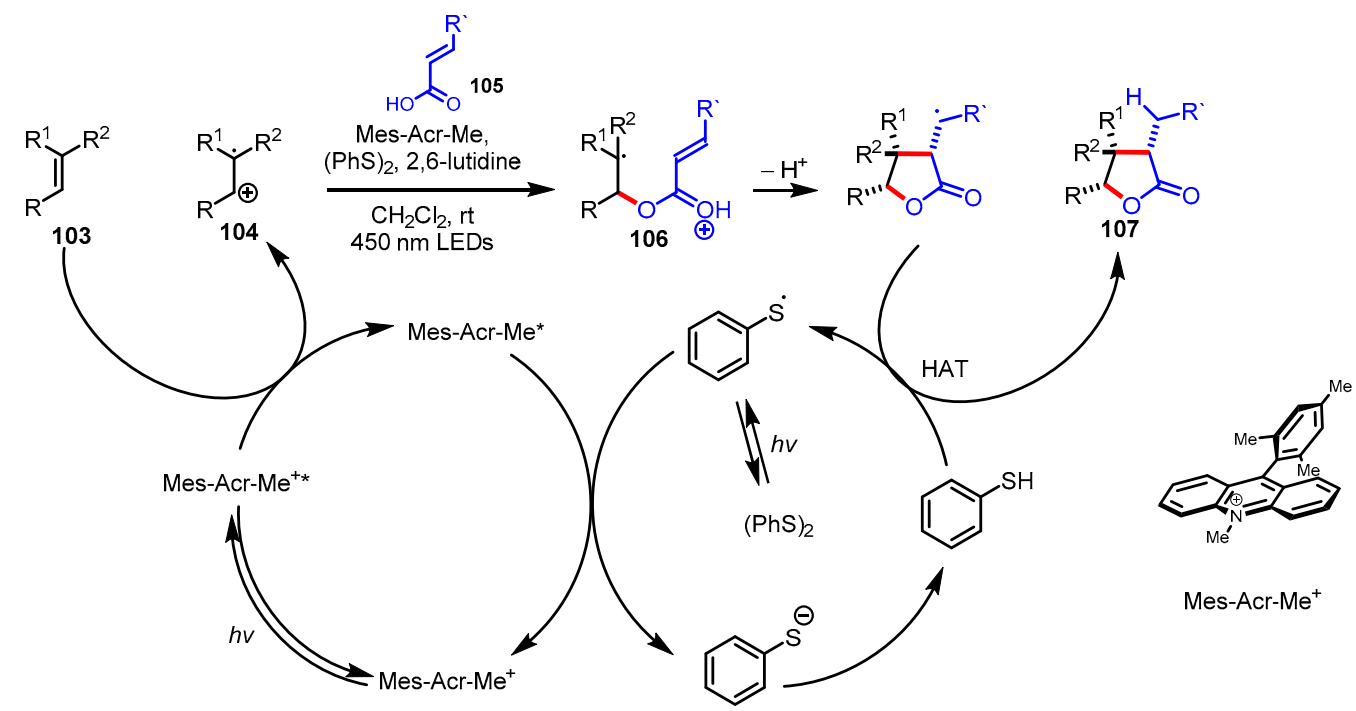

Figure 29. Polar radical crossover cycloaddition of the oxidizable alkenes and $\alpha, \beta$-unsaturated acids.

\subsubsection{Atom-Transfer Radical Addition (ATRA)}

Another example of $\gamma$-butyrolactone synthesis mediated by photoredox catalysis is atom-transfer radical addition (ATRA), which was reported by Kokotos and colleagues in 2018 [130]. ATRA has been utilized as a powerful method for one-step C-C and C-X bond formation between olefins and haloalkanes. Kokotos and colleagues applied photoredox catalysis in ATRA using $\mathrm{Ru}(\mathrm{bpy})_{3} \mathrm{Cl}_{2}$ as a photoredox catalyst, which was employed in the conversion of alkenes $\mathbf{1 1 1}$ and $\alpha$-iodoacetic acids $\mathbf{1 1 2}$ to $\gamma$-butyrolactones $\mathbf{1 1 3}$ under light irradiation. In this reaction, the excited photocatalyst is reduced by ascorbate, followed by reaction with $\alpha$-iodoacetic acid 112 to generate the electrophilic radical 114, which reacts with the alkene leading to radical $\mathbf{1 1 5}$. Then, propagation proceeded with iodoacetic acid, resulting in the formation of 116. Finally, $\gamma$-butyrolactone $\mathbf{1 1 3}$ is formed by the deprotonated carboxylic acid under basic reaction conditions (Figure 31). 


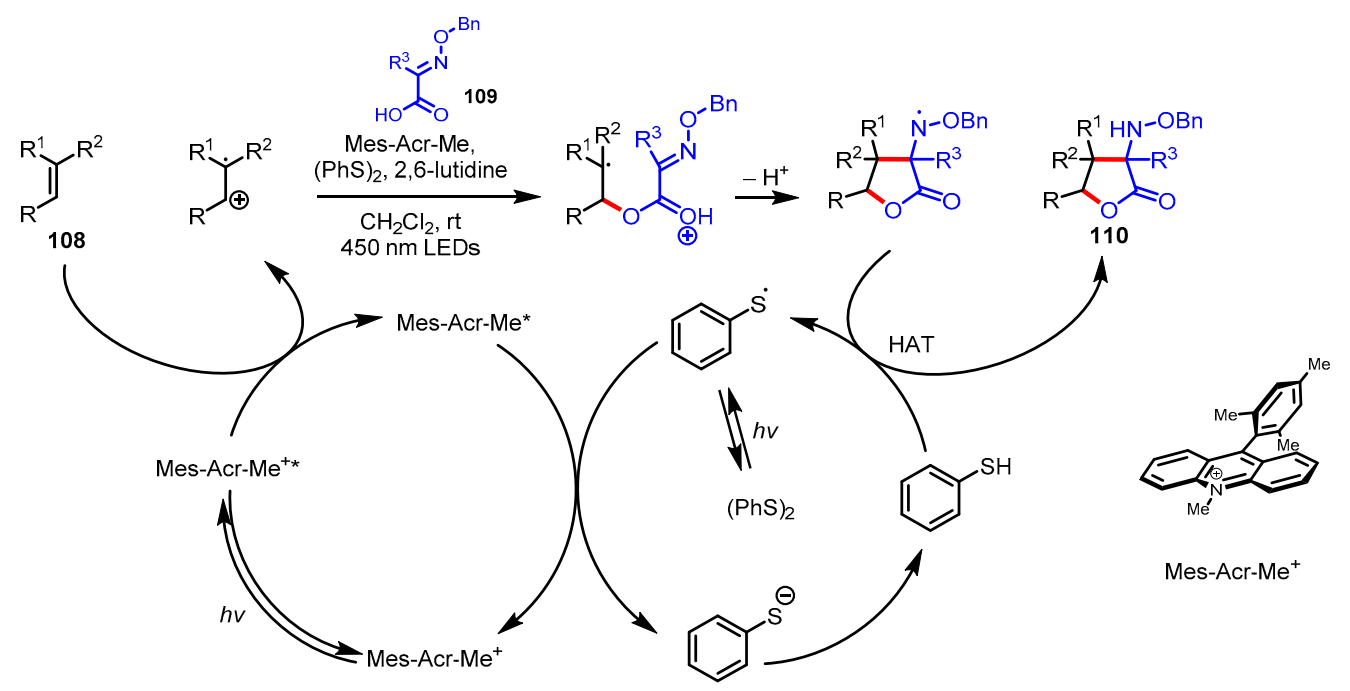

Figure 30. Polar radical crossover cycloaddition of the oxidizable alkenes and O-benzyloxime acids.

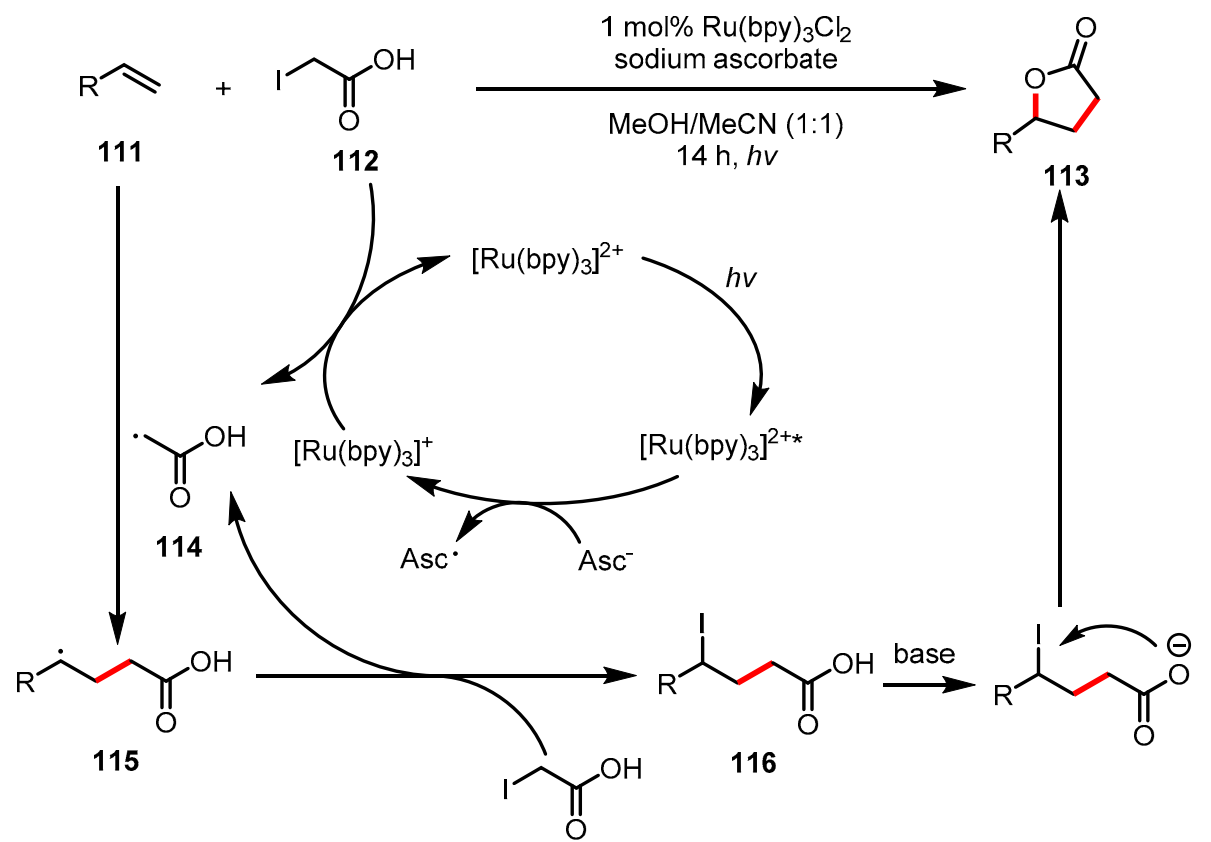

Figure 31. $\gamma$-Butyrolactone synthesis via the photoredox-catalyzed atom-transfer radical addition (ATRA).

\subsection{3. $\mathrm{Mn}(\mathrm{OAc})_{3}$-Mediated Radical Lactonization}

Manganese (III) acetate has been utilized as a versatile single-electron transfer (SET) reagent. Mukherjee and colleagues reported $\mathrm{Mn}(\mathrm{OAc})_{3}$-mediated radical lactonization to synthesize carbohydrate-based $\gamma$-butyrolactones from glycals [131]. Under sonication, a variety of 1,2-glycals and 2,3-glycals were converted to $\gamma$-butyrolactones in a regioselective and stereoselective manner, which were governed by conformational preferences for glycal substrates (Figure 32). 


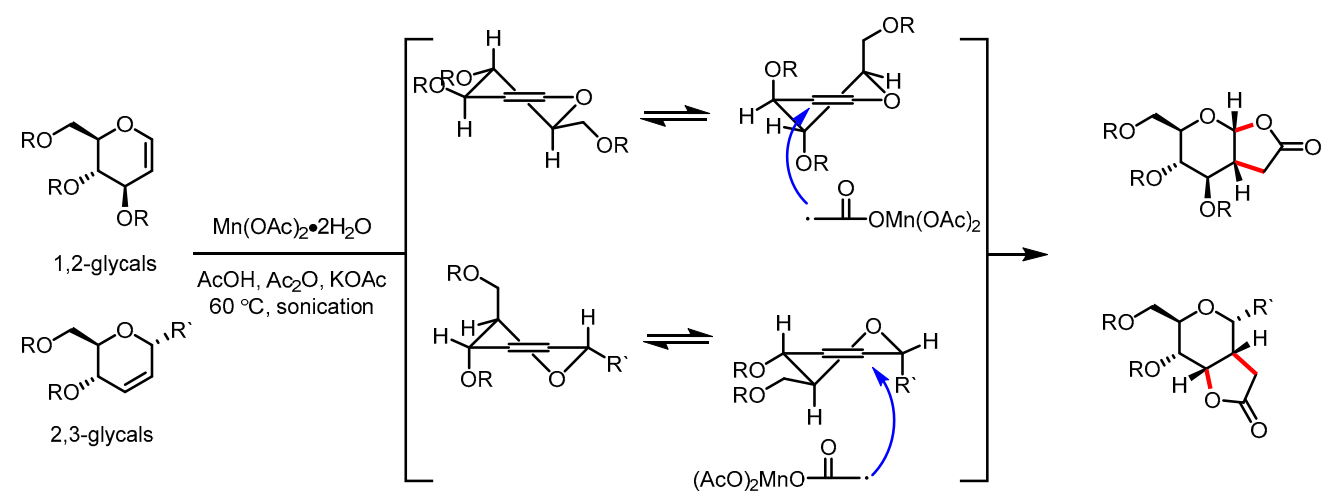

Figure 32. Synthesis of carbohydrate-based $\gamma$-butyrolactones through $\mathrm{Mn}(\mathrm{OAc})_{3}$-mediated radical lactonization.

\subsubsection{Copper-Catalyzed Cyclopropanol Ring-Opening Cross-Coupling Reaction}

Cyclopropanols 117 are versatile substrates in various ring-opening and ring-expansion reactions because of the intrinsic stain of the three-membered ring. One of the representative reactions in this class is the cyclopropanol ring-opening cross-coupling reaction mediated by diverse transition metal catalysts or single-electron transferring oxidants, resulting in the formation of a variety of $\beta$-substituted ketones. Formation of $\alpha, \beta$-unsaturated enone byproducts, which are normally caused by $\beta$-hydride elimination of the metallohomoenolate 120, is one of the major issues in this reaction. Interestingly, Dai and colleagues developed a method to accelerate $\alpha, \beta$-unsaturated carbonyl byproduct 121 by adding potassium iodide in the reaction mixture and reacting with 2-bromo-2,2-dialkyl acetate 118 to obtain $\gamma$-butyrolactones $\mathbf{1 1 9}$ bearing quaternary carbon centers, which are catalyzed by $\mathrm{Cu}(\mathrm{OTf})_{2}$ (Figure 33) [132].
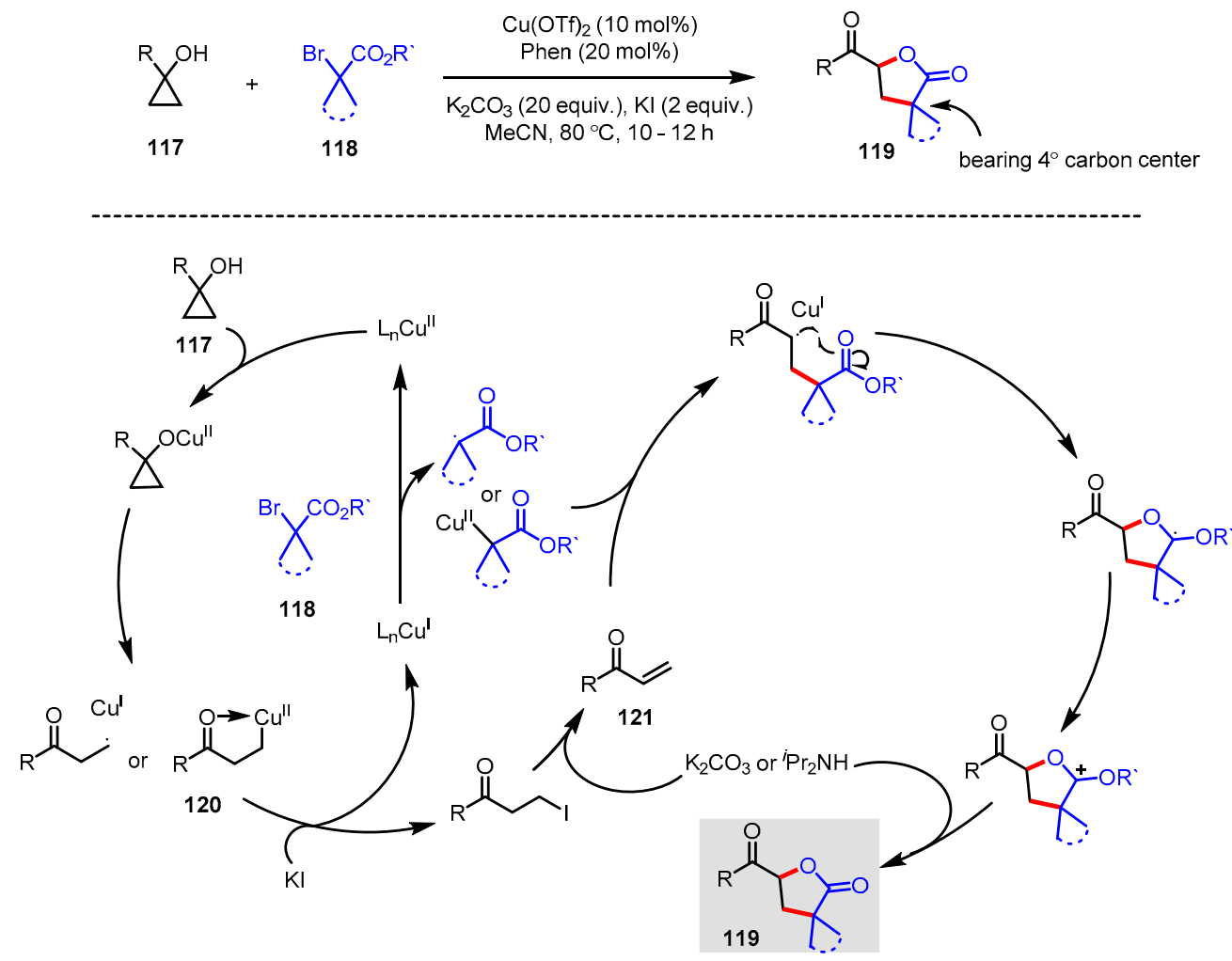

Figure 33. Synthesis of $\gamma$-butyrolactones bearing quaternary carbon centers via copper-catalyzed cyclopropanol ring-opening cross-coupling reaction. 


\subsection{Synthesis of $\gamma$-Butyrolactones via $\mathrm{C} 2-\mathrm{C} 3$ and $\mathrm{C} 2-\mathrm{O} 1$ Bonds Formation}

Carbon monoxide is used as a versatile $\mathrm{C} 1$ source in organic synthesis, thereby reacting with suitable unsaturated alcohols to afford various ring sizes of lactones [135]. There have been increasing reports of methodologies for producing $\gamma$-butyrolactones using carbonylations and hydroformylations over the past decades. However, due to the innate drawbacks of $\mathrm{CO}$, including its high toxicity, gaseous nature, and strict regulations for transportation, bypassing the direct use of $\mathrm{CO}$ gas is another significant topic in carbonylation research [135].

\subsubsection{Carbonylative Lactonization}

Among various methodologies utilizing CO gas or other carbonyl sources, transitionmetal-catalyzed carbonylative lactonization is most commonly used for $\gamma$-lactone formation. Iron pentacarbonyl is a cheap, practical surrogate of the carbonyl donor, and it was first applied to convert (amino)polyhydroxylated terminal olefins $\mathbf{1 2 2}$ into the bicyclic lactones $\mathbf{1 2 3}$ by Gracza and colleagues (Figure 34) [136]. In this system, a CO molecule is generated in situ by the assistance of copper(II) chloride and gentle heat, and subsequently participates in the palladium(II) catalysis cycle. Very recently, the same group showed that this protocol could be applicable to a continuous flow reaction in comparable yield with the batch reaction [137].

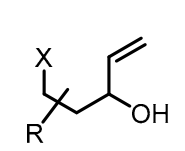

$\mathrm{X}=\mathrm{OH}$ or $\mathrm{NHBoc}$

122

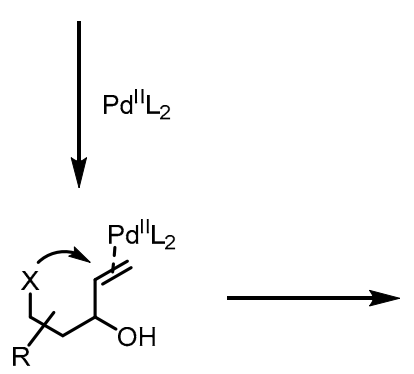

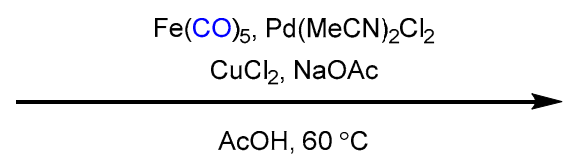

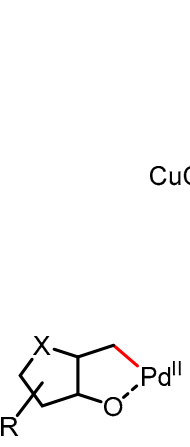

Figure 34. Synthesis of bicyclic $\gamma$-butyrolactones via palladium-catalyzed carbonylation using iron pentacarbonyl.

In 2014, Jiang and colleagues reported a unique one-pot-four-step cascade reaction in ionic liquid media by employing a palladium-catalyzed carboxylative annulation to construct highly functionalized $\gamma$-butyrolactones (Figure 35) [138]. This transformation is initiated from the trans-chloropalladation of alkynoates 124, of which the regioselectivity is governed by electronic factors. Intermediate $\mathbf{1 2 7}$ undergoes carbopalladation with butenol 125, followed by CO insertion and reductive elimination, yielding C3 functionalized $\gamma$ lactones 126 bearing a tetrasubstituted olefin unit. The imidazolium type ionic liquids played an important role during the reaction as a ligand of the palladium catalyst and as a chloride source [139]. They further demonstrated the utility of vinyl chloride functionalities in the products by employing them to Suzuki-Miyaura coupling and Negishi coupling. 


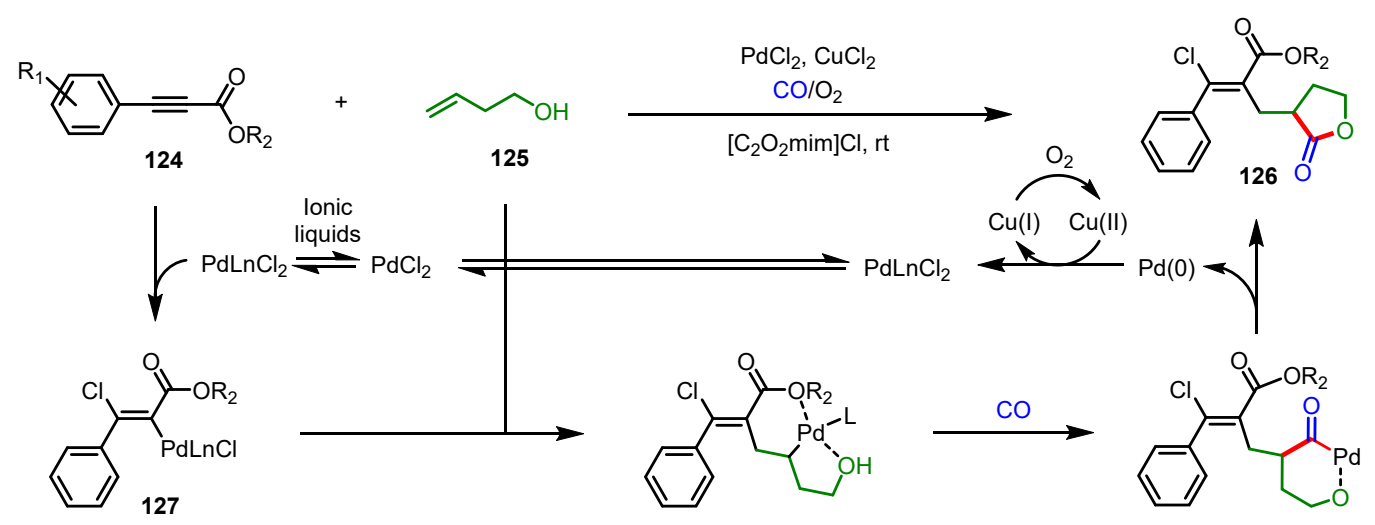

Figure 35. Synthesis of C3-substituted $\gamma$-butyrolactones via palladium-catalyzed carbonylation cascade in the ionic liquid.

Organic disulfides, which have been considered as inefficient substrates for transitionmetal-catalyzed carbonylative heteroatom addition, were successfully used as counterparts of thiolated $\alpha$-alkylidene- $\gamma$-butyrolactone synthesis in the presence of dicobalt octacarbonyl or palladium complexes such as $\mathrm{Pd}\left(\mathrm{PPh}_{3}\right)_{4}$ and $\mathrm{Pd}(\mathrm{OAc})_{2}$ (Figure 36) [140]. A variety of homopropagyl alcohols $\mathbf{1 2 8}$ and aryl disulfides produced the desired thiolated lactones $\mathbf{1 2 9}$ by both catalytic systems with high regio- and stereoselectivity (cis-isomer). Mechanistically, despite the difference in the order of metal-alkyne complexation, the presence of a hydroxy group plays a critical role in the regioselectivity of carbonyl insertion in both cases.
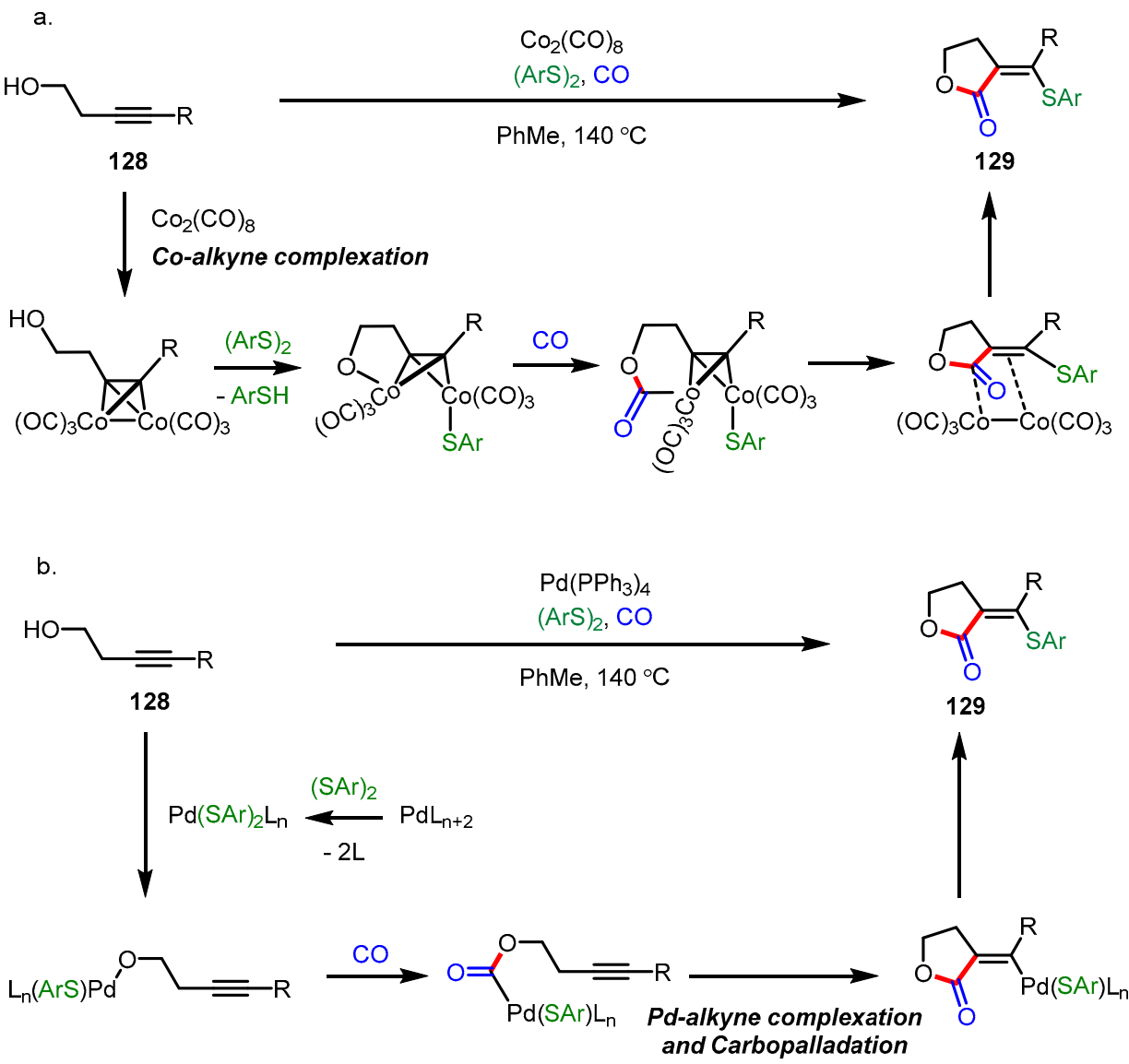

Figure 36. (a) Synthesis of thiolated $\alpha$-alkylidene- $\gamma$-butyrolactones via cobalt-catalyzed carbonylation; (b) Synthesis of thiolated $\alpha$-alkylidene- $\gamma$-butyrolactones via palladium-catalyzed carbonylation. 
C-C bonds in cyclopropanols can be easily activated by a transition-metal catalyzed ring-opening process generating metal-homoenolate species, which possess the potential of structural diversification by engaging in $\mathrm{C}_{\mathrm{sp} 3}-\mathrm{C}_{\mathrm{sp} 2}$ and $\mathrm{C}_{\mathrm{sp} 3}-\mathrm{C}_{\mathrm{sp} 3}$ cross-coupling with various counterparts [141]. Dai and colleagues combined this palladium-catalyzed C-C bond activation reaction with conventional carbonylation, and successfully constructed synthetically challenging oxaspirolactone structure 130 (Figure 37) [142]. The usefulness of this strategy was demonstrated by total syntheses of $\alpha$-levantanolide and $\alpha$-levantenolide in two and four steps, respectively (Figure 37, bottom).
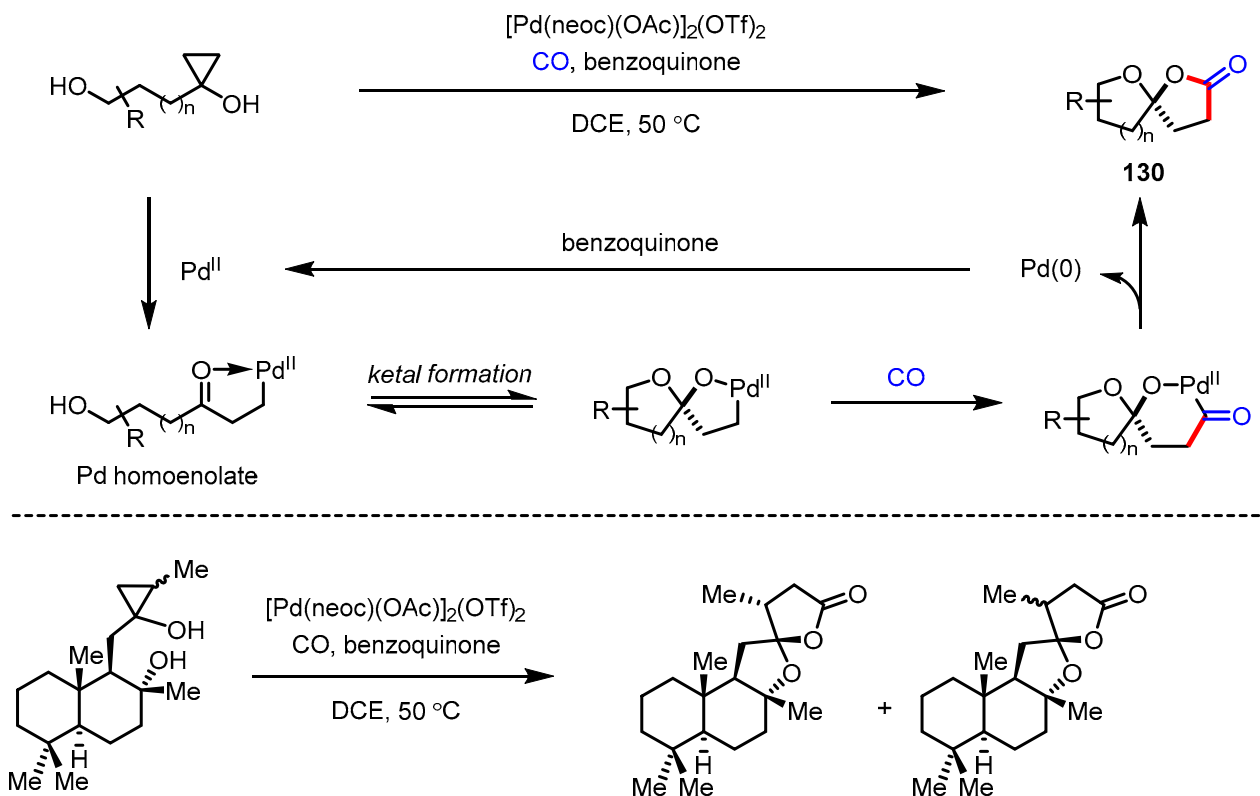

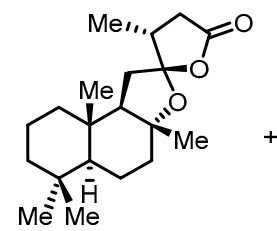

$30 \%$

$\alpha$-Levantanolide

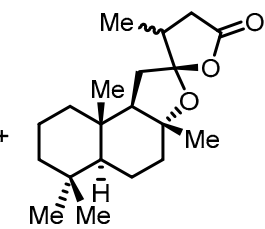

$23 \%$

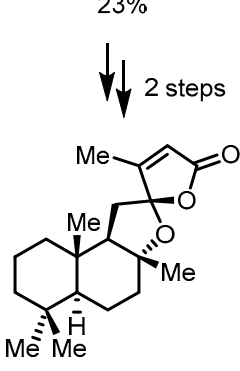

$\alpha$-Levantenolide

Figure 37. Synthesis of oxaspiro- $\gamma$-butyrolactones via palladium-catalyzed carbonylative spirolactonization and total synthesis of $\alpha$-levantanolide and $\alpha$-levantenolide.

\subsubsection{Hydroformylation-Oxidation}

The hydroformylation of olefins is one of the extensively investigated classes of carbonylation, especially for industrial applications [143]. This reaction is also applicable to $\gamma$-butyrolactone syntheses by adding a formyl group to hydroxyalkenes and subsequent oxidation of the corresponding lactols. Although the carbonyl insertion step has been known to normally take place in the anti-Markovnikov direction, Breit and colleagues successfully converted 1,1-disubstituted homoallylic alcohols $\mathbf{1 3 1}$ into the desired $\gamma$-lactones 132 containing quaternary carbon at the $\alpha$-position (Figure 38) [144]. The key to this achievement was the use of a phosphinite as a removable catalyst-directing group. Diphenylphosphinites $\mathbf{1 3 3}$ was formed via transesterification with a catalytic amount of $\mathrm{Ph}_{2} \mathrm{POMe}$ and the resulting phosphinite group-guided approach of the rhodium hydride complex afforded a favorable six-membered cyclic hydrometallation transition state $\mathbf{1 3 4}$. 


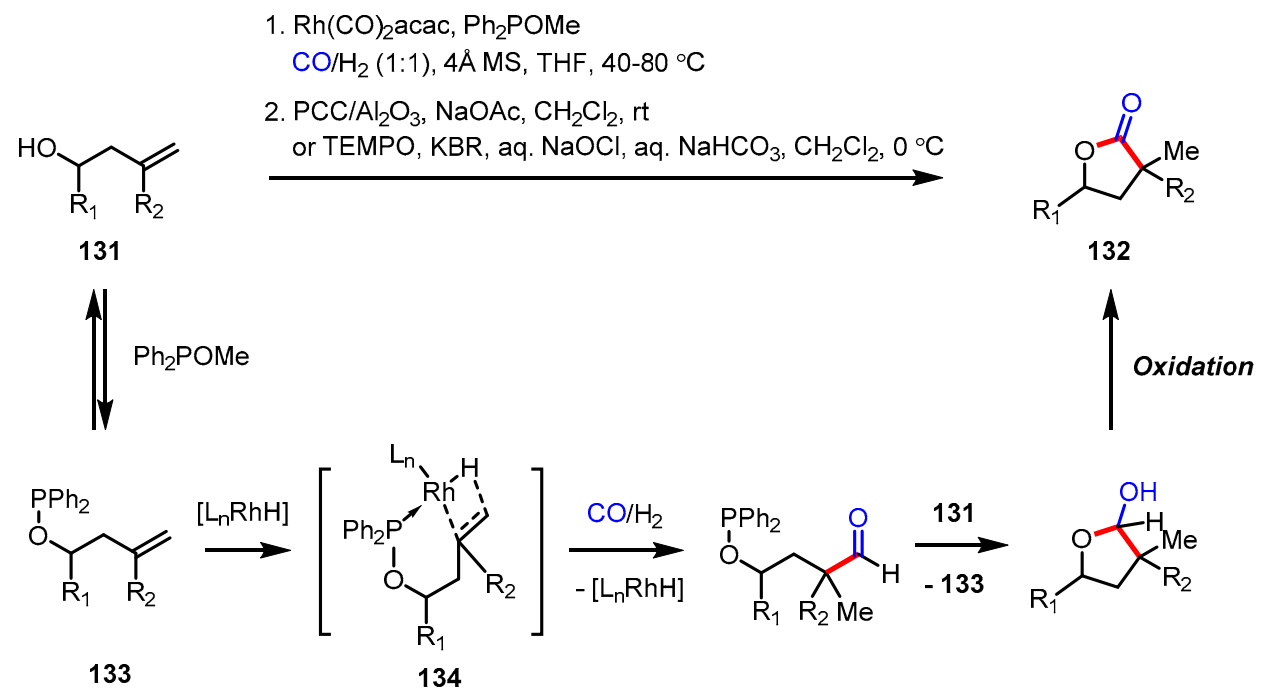

Figure 38. Synthesis of 3,3,5-trisubstituted- $\gamma$-butyrolactones via rhodium-catalyzed Markovnikov hydroformylation and oxidation.

The enantioselective hydroformylation of 1,1-disubstituted olefins has proven to be unproductive, presumably due to the steric repulsion of an olefin coordination with a metal center [145]. Very recently, Zhang and colleagues addressed this challenge by modifying conventional chiral ligands to more sterically demanding variants (Figure 39) [146]. Under the optimized conditions, the hydroformylation of allylic alcohol 135 occurred following the anti-Markovnikov rule in high ee values, producing the corresponding optically active lactol. The lactol was able to be transformed into not only the desired optically active lactone 136 via PCC oxidation, but also into the tetrahydrofuran derivative via reduction or allylation.

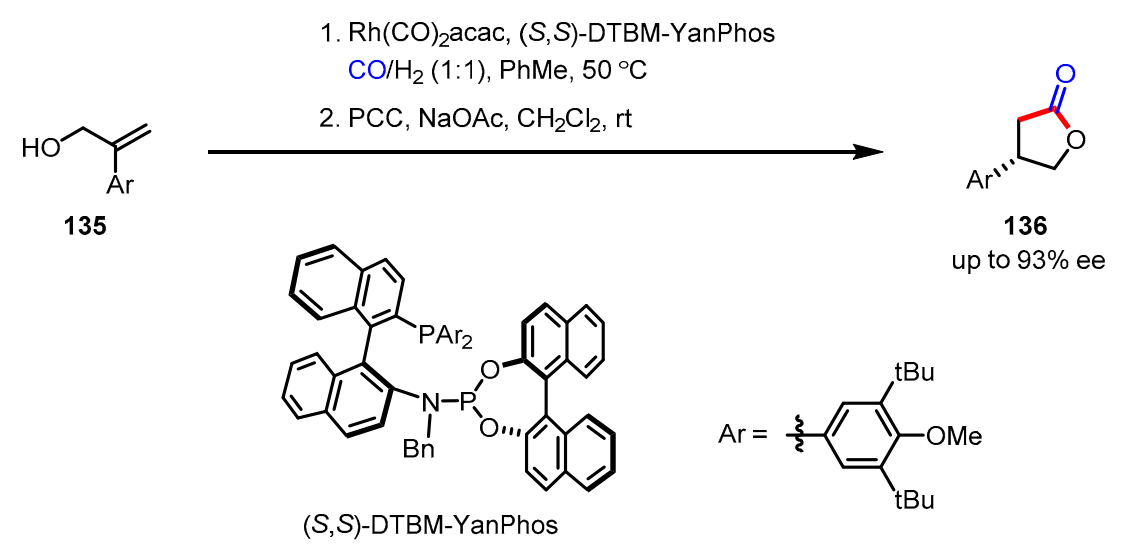

Figure 39. Asymmetric synthesis of 4-substituted $\gamma$-butyrolactones via rhodium-catalyzed hydroformylation and oxidation.

\subsubsection{Carboxylation-Lactonization}

Carbon dioxide is the most abundant $\mathrm{C} 1$ source on earth; thus, harnessing this molecule would be appealing with respect to the development of economical and environmentally friendly synthetic methods. Nevertheless, due to the chemically inert nature of $\mathrm{CO}_{2}$ gas, carboxylation $\left(\mathrm{CO}_{2}\right.$ activation) has been less widespread than carbonylation (CO activation). The nickel-catalyzed methyl-carboxylation of homopropagylic alcohols 137 met this demand, affording $\alpha$-alkylidene- $\gamma$-butyrolactones 138 in a regio- and stereoselective manner (Figure 40) [147]. Ma and colleagues discovered that this catalytic system only required $1 \mathrm{~mol} \%$ of $\mathrm{Ni}$ catalyst for $\mathrm{CO}_{2}$ activation and proceeded with broad functional group tolerance. The excellent regioselectivity may derive from the directing effect 
of the adjacent hydroxy group. The potential of this methodology was illustrated through the first total synthesis of $( \pm)$-heteroplexisolide E 139 [148].

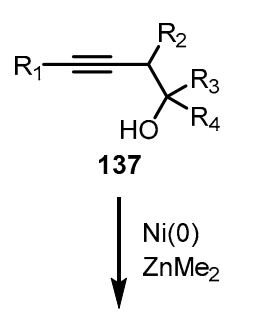

1. $\mathrm{Ni}(\operatorname{cod})_{2}, \mathrm{CsF}, \mathrm{ZnMe}_{2}, \mathrm{CO}_{2}, \mathrm{MeCN}, 50^{\circ} \mathrm{C}$

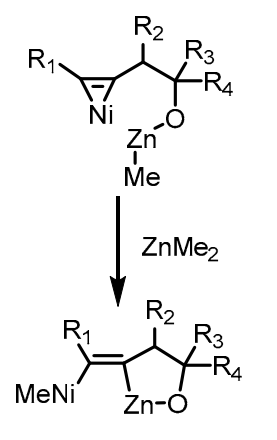
2. $\mathrm{HCl}$ or PTSA
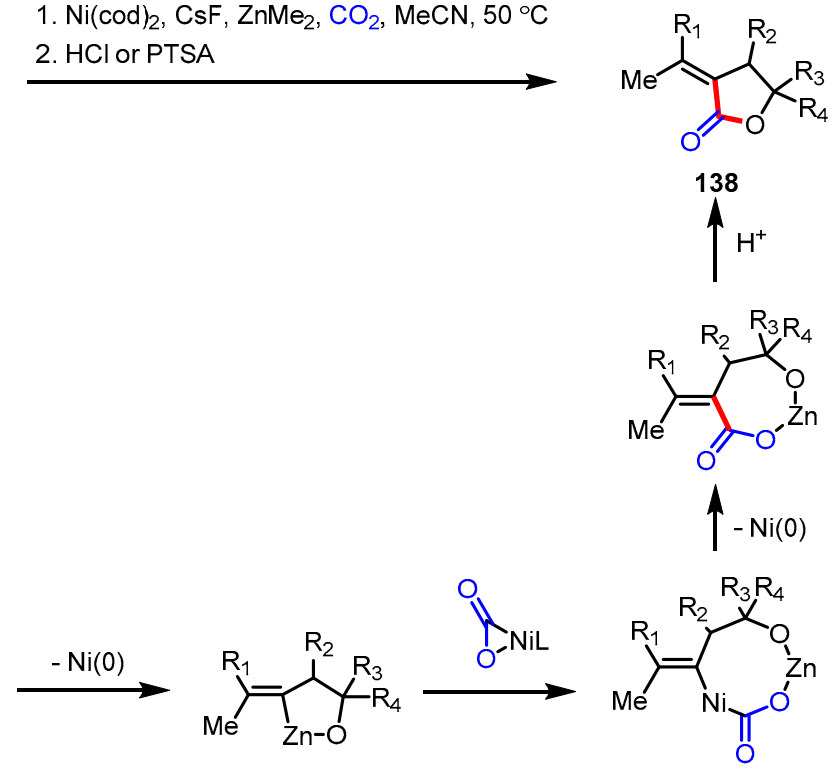

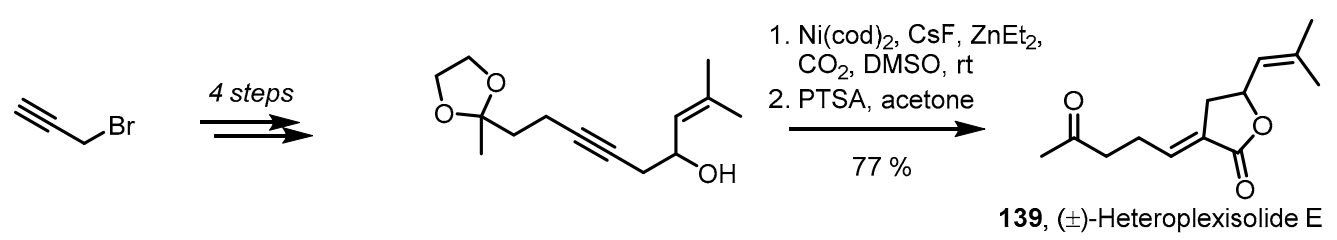

Figure 40. Synthesis of $\alpha$-alkyledene $\gamma$-butyrolactones via $\mathrm{Ni}(0)$-catalyzed carboxylation and total synthesis of $( \pm)$-heteroplexisolide $\mathrm{E}$.

\subsection{Synthesis of $\gamma$-Butyrolactones via C3-C4 Bond Formation C-H Insertion}

Over the past several decades, Rh-catalyzed intramolecular C-H insertion has been intensively investigated and established as a powerful tool for the construction of structurally diverse cyclic compounds. Unsworth and colleagues reported a one-pot C-H insertion/olefination sequence to afford $\alpha$-alkylidene- $\gamma$-butyrolactones (Figure 41) [149]. Rh-catalyzed C-H insertion of diazo compound 140 gave $\alpha$-phosphonated $\gamma$-lactone 141, which was subsequently converted to $\alpha$-alkylidene- $\gamma$-lactone 142 via Horner-WadsworthEmmons-type olefination. A variety of $\gamma$-lactones were obtained in a one-pot procedure in useful yields. The versatility of this protocol was demonstrated by the successful synthesis of natural products, cedamycin A, B, and eudesmanolide $[150,151]$.

\subsection{Synthesis of $\gamma$-Butyrolactones via Oxidative C2-O1 Bond Formation}

A simple $\gamma$-butyrolactone is itself a broadly used material [152] as a solvent, extraction agent, and intermediate for polymers, pharmaceutics, herbicides, rubber production, etc. The oxidative lactonization of 1,4-butanediol under an efficient catalytic system has been a dominant industrial process because of its significant advantages [152]. This method does not produce any waste except for reusable hydrogen gas. Additionally, 1,4-butanediol can be obtained from renewable biomass such as glucose [153]. For these reasons, it is not surprising that many researchers have intensively modified this route to be more efficient and environmentally benign than conventional methods. The representative oxidative lactonization conditions recently developed for the synthesis of $\gamma$-butyrolactones from 1,4-butanediol are summarized in Table 4. 


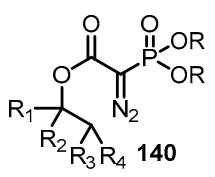

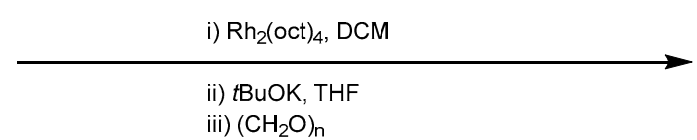

iii) $\left(\mathrm{CH}_{2} \mathrm{O}\right)_{n}$<smiles></smiles><smiles>[R]C([R])([Y])OC(=O)C(=O)S(=O)(=O)O</smiles>

C-H insertion
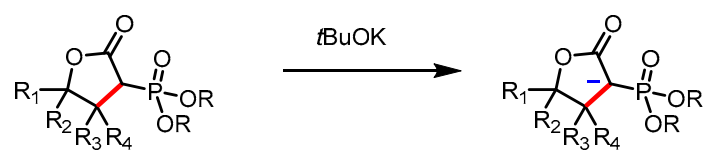

141

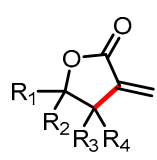

$\left(\mathrm{CH}_{2} \mathrm{O}\right)_{n} \uparrow$

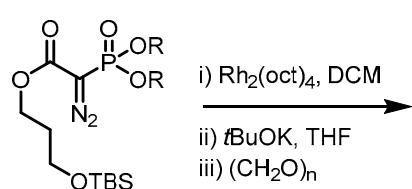<smiles>C=C1CC1CC1CC1COC(C)(C)C</smiles><smiles>[R]C(C)CCCC(=O)OCC1COC(=O)C1=C</smiles>

$\mathrm{R}=\mathrm{Me}$, cedarmycin $\mathrm{A}$ $\mathrm{R}=\mathrm{H}$, cedarmycin $\mathrm{B}$<smiles>[R]CCC1CCCC(OC(=O)C(=N)P([R])([R])=O)C1CC[R]</smiles>

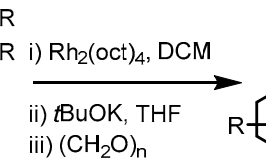<smiles>C=C1C(=O)O[C@@H]2[C@H]3CC[C@@H](CC[C@H]12)C3</smiles><smiles>C=CC</smiles><smiles>C=C1C(=O)OC2C1CC[C@]1(C)CCC=C(C)C21</smiles><smiles>C=C1CCC[C@]2(C)CC[C@H]3C(=C)C(=O)OC3C12</smiles>

Eudesmanolide natural products

Figure 41. Synthesis of $\gamma$-butyrolactones and natural products via Rh-catalyzed C-H insertion.

Table 4. Recent reports for $\gamma$-butyrolactone synthesis from 1,4-butanediol.

\begin{tabular}{|c|c|c|c|}
\hline \multicolumn{3}{|c|}{ Conditions } & \multirow[b]{2}{*}{ Ref } \\
\hline Entry & Method & Catalyst & \\
\hline 1 & Vapor phase reaction & $\mathrm{Cu}-\mathrm{SiO}_{2}$ nonocomposite & [154] \\
\hline 2 & Vapor phase reaction & $\mathrm{SiO}_{2}$ supported $\mathrm{Cu}, \mathrm{Ca}, \mathrm{Sr}$ or $\mathrm{Br}$ promoter & [155] \\
\hline $3^{1}$ & Vapor phase reaction & $\mathrm{MgO}$ supported $\mathrm{Cu}$ & [156] \\
\hline $4^{2}$ & Vapor phase reaction & $\mathrm{CaAlO}$ supported $\mathrm{Cu}$ & [157] \\
\hline $5^{3}$ & Vapor phase reaction & $\mathrm{MgO}$ supported $\mathrm{Cu}, \mathrm{Co}_{3} \mathrm{O}_{4}$ promoter & [158] \\
\hline $6^{4}$ & Vapor phase reaction & $\mathrm{MgO}$ supported $\mathrm{Cu}$ & [159] \\
\hline 7 & Vapor phase reaction & $\mathrm{ZrO}_{2}$ supported $\mathrm{Cu}, \mathrm{La}_{2} \mathrm{O}_{3}$ promoter & [160] \\
\hline $8^{5}$ & Vapor phase reaction & $\mathrm{CeO}_{2}-\mathrm{Al}_{2} \mathrm{O}_{3}$ supported $\mathrm{Cu}$ & [161] \\
\hline $9^{6}$ & Continuous flow reaction & AlOx supported Cu nanoparticle & [162] \\
\hline 10 & Chemoenzymatic reaction & Type II FMO-E and HLADH & [163] \\
\hline 11 & Chemoenzymatic reaction & HLADH & [164] \\
\hline 12 & Heterogeneous solution phase reaction & $\mathrm{SnO}_{2}$ supported $\mathrm{Au}$ & [165] \\
\hline 13 & Heterogeneous solution phase reaction & $\mathrm{Mn}_{2} \mathrm{O}_{3}$ supported $\mathrm{Au}$ & [166] \\
\hline 15 & Homogeneous solution phase reaction & $\mathrm{Cu} /$ nitroxyl & [167] \\
\hline 16 & Homogeneous solution phase reaction & Fe complex 143 & [168] \\
\hline 17 & Homogeneous solution phase reaction & Fe complex 144 & [169] \\
\hline 18 & Homogeneous solution phase reaction & Fe complex 145 & [170] \\
\hline 19 & Homogeneous solution phase reaction & Fe complex 146 & [171] \\
\hline
\end{tabular}

${ }^{1}$ Simultaneous hydrogenation of acetophenone; ${ }^{2}$ Simultaneous hydrogenation of furfural alcohol; ${ }^{3}$ Simultaneous hydrogenation of nitrobenzene; ${ }^{4}$ Simultaneous hydrogenation of ortho-chloronitrobenzene. ${ }^{5}$ Simultaneous hydrogenation of benzaldehyde; ${ }^{6}$ Simultaneous hydrogenolysis of furfural derivatives. 


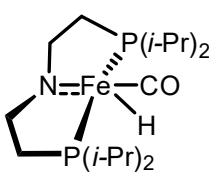

143

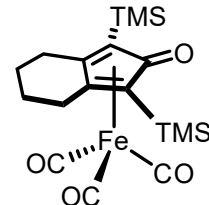

144

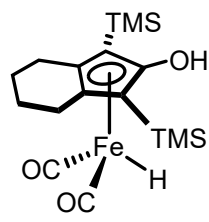

145

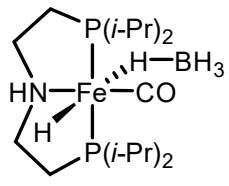

146

\section{Conclusions}

$\gamma$-Butyrolactones have been broadly studied in drug discovery, resulting in the identification of diverse biologically active small molecules containing $\gamma$-butyrolactone. Moreover, significant efforts to develop efficient and concise synthetic strategies toward $\gamma$ butyrolactone moiety have been reported in recent years utilizing readily available starting materials and newly developed reactions. The construction of diverse biologically active natural products and synthetic pharmaceuticals bearing $\gamma$-butyrolactone are allowed with these novel strategies. This review includes a brief overview of biologically active $\gamma$-butyrolactones and a summary of the representative synthetic methodologies toward $\gamma$ butyrolactones developed between 2010 and 2020, which are classified in the seven sections based on the sites of bond formation (Table 5) and described their reaction mechanism and further application in the synthesis of biologically active molecules. This update will help to develop biologically active new $\gamma$-butyrolactones and to solve hurdles in the synthesis of $\gamma$-butyrolactone-bearing natural products and pharmaceuticals as well as to develop novel synthetic approaches toward $\gamma$-butyrolactones.

Table 5. Summary of synthetic methodologies for the synthesis of $\gamma$-butyrolactones (2010-2020).

\begin{tabular}{|c|c|c|c|}
\hline Section & Bond Formation & Reaction & Page \\
\hline \multirow{5}{*}{3.1} & & Oxidative lactonization & 12 \\
\hline & & Halolactonization & 14 \\
\hline & & Acid-promoted cyclopropane opening & 15 \\
\hline & & Au-catalyzed oxaallylation & 16 \\
\hline & & Photoredox-catalyzed lactonization & 17 \\
\hline \multirow{4}{*}{3.2} & & Transition-metal catalyzed C-C bond coupling & 18 \\
\hline & & NHC-catalyzed C-C bond coupling & 20 \\
\hline & & Photoredox-catalyzed C-C bond coupling & 23 \\
\hline & & Miscellsious $\gamma$-butyrolactone formation & 24 \\
\hline \multirow{2}{*}{3.3} & & Ruthenium pincer-catalyzed hydrogen autotransfer & 27 \\
\hline & & Ionic liquid-assisted epoxide opening and lactonization & 27 \\
\hline \multirow{4}{*}{3.4} & & Polar radical crossover cycloaddition (PRCC) & 28 \\
\hline & & Atom-transfer radical addition (ATRA) & 29 \\
\hline & & $\mathrm{Mn}(\mathrm{OAc})_{3}$-mediated radical lactonization & 30 \\
\hline & & Copper-catalyzed cyclopropanol ring-opening cross-coupling & 30 \\
\hline \multirow{3}{*}{3.5} & & Carbonylative lactonization & 31 \\
\hline & & Hydroformylation-oxidation & 33 \\
\hline & & Carboxylation-lactonization & 35 \\
\hline 3.6 & & C-H insertion & 36 \\
\hline 3.7 & & Oxidative $\mathrm{C} 2-\mathrm{O} 1$ bond formation & 37 \\
\hline
\end{tabular}


Author Contributions: Conceptualization, J.H., J.J. and J.S.; writing-original draft preparation, J.H., J.J. and J.S.; writing-review and editing, J.H., J.J. and J.S.; supervision, J.J. and J.S.; funding acquisition, J.S. All authors have read and agreed to the published version of the manuscript.

Funding: This work was supported by the National Research Foundation of Korea (NRF) grant funded by Korea government (MSIT) (No. 2020R1G1A1102355) and research fund of Chungnam National University.

Institutional Review Board Statement: Not applicable.

Informed Consent Statement: Not applicable.

Data Availability Statement: Not applicable.

Acknowledgments: We thank all the researchers cited in this review. We are exceedingly grateful for the invitation to contribute to this Special Issue.

Conflicts of Interest: The authors declare no conflict of interest.

\section{Abbreviations}

$\left[\mathrm{C}_{2} \mathrm{O}_{2} \mathrm{mim}\right] \mathrm{Cl}$ 1-carboxymethyl-3-methylimidazolium chloride

Ac

Acetyl

acac

Acetylacetone

Acr

Acridinium

Ar

Aryl

ATRA

Bn

Atom-transfer radical addition

Boc

Benzyl

bpy

tert-Butyloxycarbonyl

$\mathrm{Bu}$

$2,2^{\prime}$ - bipyridine

CDI

cod

Butyl

$\mathrm{Cp}$

Carbonyldiimidazole

1,5-Cyclooctadiene

$\mathrm{DBU}$

Cyclopentadienyl

DCE

1,8-Diazabicyclo(5.4.0)undec-7-ene

$\mathrm{dF}\left(\mathrm{CF}_{3}\right)$ ppy

1,2-Dichloroethane

DFT

2-(2,4-Difluorophenyl)-5-(trifluoromethyl)pyridine

DKR

Density functional theory

Dmim

Dynamic kinetic resolution

DMSO

1,3-Dimethylimidazolium

DPPP

Dimethyl sulfoxide

dtbbpy

1,3-Bis(diphenylphosphino)propane

EDC

4,4'-Di-tert-butyl-2,2'-bipyridine

Et 1-Ethyl-3-(3-dimethylaminopropyl)carbodiimide

FMO

HAT

Flavin-containing monooxygenase

HATU

Hydrogen atom transfer

Hbim 1-[Bis(dimethylamino)methylene]-1H-1,2,3-triazolo[4,5-b]pyridinium3-

HLADH

HOBt oxide hexafluorophosphate

LED

1-Dutylimidazolium

Horse liver alcohol dehydrogenase

$\mathrm{Me}$

1-Hydroxybenzotriazole

Light-emitting diode

Mes

Methyl

Mesitylene

MS

Molecular sieve

NBS

$N$-Bromosuccinimide

neoc

Neocuproine

NHC

$N$-heterocyclic carbene

Pc

Phthalocyanine

PCC

Pyridinium chlorochromate 


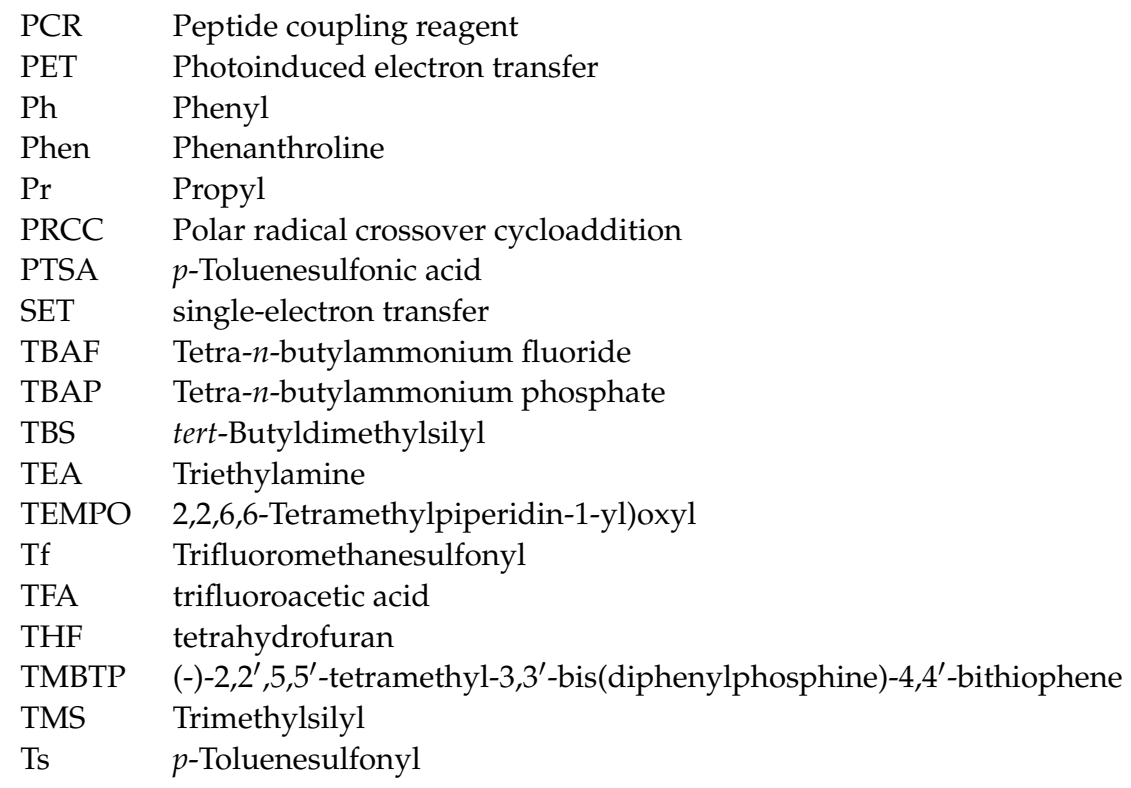

\section{References}

1. Omura, S.; Tanaka, H.; Okada, Y.; Marumo, H. Isolation and structure of nanaomycin D, an enantiomer of the antibiotic kalafungin. J. Chem. Soc. Chem. Commun. 1976, 213, 320-321. [CrossRef]

2. Yamawaki, M.; Nishi, K.; Nishimoto, S.; Yamauchi, S.; Akiyama, K.; Kishida, T.; Maruyama, M.; Nishiwaki, H.; Sugahara, T. Immunomodulatory effect of (-)-matairesinol in vivo and ex vivo. Biosci. Biotechnol. Biochem. 2011, 75, 859-863. [CrossRef] [PubMed]

3. Zhangabylov, N.S.; Dederer, L.Y.; Gorbacheva, L.B.; Vasil'eva, S.V.; Terekhov, A.S.; Adekenov, S.M. Sesquiterpene lactone arglabin influences DNA synthesis in P388 leukemia cells in vivo. Pharm. Chem. J. 2004, 38, 651-653. [CrossRef]

4. Rudolphi, K.; Gerwin, N.; Verzijl, N.; van der Kraan, P.; van den Berg, W. Pralnacasan, an inhibitor of interleukin-1 $\beta$ converting enzyme, reduces joint damage in two murine models of osteoarthritis. Osteoarthr. Cart. 2003, 11, 738-746. [CrossRef]

5. Chowdhury, R.; Ghosh, S.K. Organo-catalyzed enantioselective synthesis of some $\beta$-silyl $\gamma$-alkyl $\gamma$-butyrolactones as intermediates for natural products. Tetrahedron Asymmetry 2011, 22, 1895-1900. [CrossRef]

6. $\quad$ Ok, T.; Jeon, A.; Lee, J.; Jung, H.L.; Chang, S.H.; Lee, H.S. Enantiomerically pure synthesis of $\beta$-substituted $\gamma$-butyrolactones: A key intermediate to concise synthesis of pregabalin. J. Org. Chem. 2007, 72, 7390-7393. [CrossRef] [PubMed]

7. Brown, E.; Daugan, A. An easy preparation of (-) and (+)- $\beta$-piperonyl- $\gamma$-butyrolactones, key-intermediates for the synthesis of optically active lignans. Tetrahedron Lett. 1985, 26, 3997-3998. [CrossRef]

8. Bielitza, M.; Pietruszka, J. An enantioselective Mukaiyama aldol reaction as the key step towards the tetrahydropyran core of psymberin via a $\gamma$-butyrolactone intermediate. Synlett 2012, 23, 1625-1628.

9. Givens, R.S.; Oettle, W.F. Photorearrangement of a $\gamma$-butyrolactone: Generation of intermediates in photochemical reactions. Anal. Proc. 1969, 1164-1165. [CrossRef]

10. Vinet, L.; Zhedanov, A. A "missing" family of classical orthogonal polynomials. J. Phys. A Math. Theor. 2011, 44, 51. [CrossRef]

11. Murauski, K.J.R.; Jaworski, A.A.; Scheidt, K.A. A continuing challenge: $N$-heterocyclic carbene-catalyzed syntheses of $\gamma$ butyrolactones. Chem. Soc. Rev. 2018, 47, 1773-1782. [CrossRef] [PubMed]

12. Kitson, R.R.A.; Millemaggi, A.; Taylor, R.J.K. The renaissance of $\alpha$-methylene- $\gamma$-butyrolactones: New synthetic approaches. Angew. Chem. Int. Ed. 2009, 48, 9426-9451. [CrossRef] [PubMed]

13. Mao, B.; Fañanás-Mastral, M.; Feringa, B.L. Catalytic asymmetric synthesis of butenolides and butyrolactones. Chem. Rev. 2017, 117, 10502-10566. [CrossRef]

14. Seitz, M.; Reiser, O. Synthetic approaches towards structurally diverse $\gamma$-butyrolactone natural-product-like compounds. Curr. Opin. Chem. Biol. 2005, 9, 285-292. [CrossRef] [PubMed]

15. Vivino, F.; Al-Hashimi, I.; Khan, Z. Pilocarpine Tablets for the Treatment of Dry Mouth and Dry Eye Symptoms in Patients With Sjogren Syndrome. Arch. Intern. Med. 1999, 159, 174-181. [CrossRef]

16. Kagawa, C.M.; Cella, J.A.; Van Arman, C.G. Action of New Steroids in Blocking Effects of Aldosterone and Deoxycorticosterone on Salt. Science 1957, 126, 1015-1016. [CrossRef]

17. Struthers, A.; Krum, H.; Williams, G.H. A comparison of the aldosterone-blocking agents eplerenone and spironolactone. Clin. Cardiol. 2008, 31, 153-158. [CrossRef] [PubMed]

18. Krattenmacher, R. Drospirenone: Pharmacology and pharmacokinetics of a unique progestogen. Contraception 2000, 62, 29-38. [CrossRef]

19. Xu, H.; Lv, M.; Tian, X. A Review on Hemisynthesis, Biosynthesis, Biological Activities, Mode of Action, and Structure-Activity Relationship of Podophyllotoxins: 2003-2007. Curr. Med. Chem. 2009, 16, 327-349. [CrossRef] 
20. Yang, J.; Bogni, A.; Schuetz, E.G.; Ratain, M.; Eileen Dolan, M.; McLeod, H.; Gong, L.; Thorn, C.; Relling, M.V.; Klein, T.E.; et al. Etoposide pathway. Pharm. Genom. 2009, 19, 552-553. [CrossRef] [PubMed]

21. Clark, P.I.; Slevin, M.L. The Clinical Pharmacology of Etoposide and Teniposide. Clin. Pharm. 1987, 12, 223-252. [CrossRef] [PubMed]

22. Tantry, U.S.; Liu, F.; Chen, G.; Gurbel, P.A. Vorapaxar in the secondary prevention of atherothrombosis. Expert Rev. Cardiovasc. Ther. 2015, 13, 1293-1305. [CrossRef] [PubMed]

23. Chen, H.; Wu, G.; Gao, S.; Guo, R.; Zhao, Z.; Yuan, H.; Liu, S.; Wu, J.; Lu, X.; Yuan, X.; et al. Discovery of Potent Small-Molecule Inhibitors of Ubiquitin-Conjugating Enzyme UbcH5c from $\alpha$-Santonin Derivatives. J. Med. Chem. 2017, 60, 6828-6852. [CrossRef] [PubMed]

24. Sun, Q.; Zhang, W. Tetrahydronaphtho[1,2-b]furan-2(3H)-One Derivatives and Their Preparation, Pharmaceutical Compositions and Use in the Treatment of Rheumatoid Arthritis. WO2019011285, 17 January 2019.

25. Chen, L.Z.; Wu, J.; Li, K.; Wu, Q.Q.; Chen, R.; Liu, X.H.; Ruan, B.F. Novel phthalide derivatives: Synthesis and anti-inflammatory activity in vitro and in vivo. Eur. J. Med. Chem. 2020, 206, 112722. [CrossRef] [PubMed]

26. Ruan, B.; Li, Y. Resveratrol-Phthalide Hybrid Compound for Anti-Inflammatory Research and Its Preparation Method. CN110105316, 9 August 2019.

27. Tran, Q.T.N.; Wong, W.S.F.; Chai, C.L.L. The identification of naturally occurring labdane diterpenoid calcaratarin D as a potential anti-inflammatory agent. Eur. J. Med. Chem. 2019, 174, 33-44. [CrossRef]

28. Siedle, B.; García-Piñeres, A.J.; Murillo, R.; Schulte-Mönting, J.; Castro, V.; Rüngeler, P.; Klaas, C.A.; Da Costa, F.B.; Kisiel, W.; Merfort, I. Quantitative structure-activity relationship of sesquiterpene lactones as inhibitors of the transcription factor NF- $\mathrm{kB}$. J. Med. Chem. 2004, 47, 6042-6054. [CrossRef]

29. Nicolaou, K.C.; Sanchini, S.; Sarlah, D.; Lu, G.; Wu, T.R.; Nomura, D.K.; Cravatt, B.F.; Cubitt, B.; De La Torre, J.C.; Hessell, A.J.; et al. Design, synthesis, and biological evaluation of a biyouyanagin compound library. Proc. Natl. Acad. Sci. USA 2011, 108, 6715-6720. [CrossRef] [PubMed]

30. Yang, Y.N.; Huang, X.Y.; Feng, Z.M.; Jiang, J.S.; Zhang, P.C. New Butyrolactone Type Lignans from Arctii Fructus and Their Anti-inflammatory Activities. J. Agric. Food Chem. 2015, 63, 7958-7966. [CrossRef] [PubMed]

31. Singh, P.; Mittal, A.; Bhardwaj, A.; Kaur, S.; Kumar, S. 1-Toluene-sulfonyl-3-[(3'-hydroxy-5'-substituted)- $\gamma$-butyrolactone]-indoles: Synthesis, COX-2 inhibition and anti-cancer activities. Bioorganic Med. Chem. Lett. 2008, 18, 85-89. [CrossRef]

32. Brethon, A.; Chantalat, L.; Christin, O.; Clary, L.; Fournier, J.F.; Gastreich, M.; Harris, C.S.; Isabet, T.; Pascau, J.; Thoreau, E.; et al. New Caspase-1 inhibitor by scaffold hopping into bio-inspired 3D-fragment space. Bioorganic Med. Chem. Lett. 2017, 27, 5373-5377. [CrossRef] [PubMed]

33. Tanaka, K.; Itazaki, H.; Yoshida, T. Cinatrins, a novel family of phospholipase a2 inhibitors: II. Biological activities. J. Antibiot. 1992, 45, 50-55. [CrossRef] [PubMed]

34. Brisdelli, F.; Perilli, M.; Sellitri, D.; Piovano, M.; Garbarino, J.A.; Nicoletti, M.; Bozzi, A.; Amicosante, G.; Celenza, G. Cytotoxic activity and antioxidant capacity of purified lichen metabolites: An in vitro study. Phyther. Res. 2013, 27, 431-437. [CrossRef] [PubMed]

35. Roy, P.K.; Roy, S.; Ueda, K. New cytotoxic cembranolides from an Okinawan soft coral, Lobophytum sp. Fitoterapia 2019, 136, 104162. [CrossRef] [PubMed]

36. Salaski, E.J.; Krishnamurthy, G.; Ding, W.D.; Yu, K.; Insaf, S.S.; Eid, C.; Shim, J.; Levin, J.I.; Tabei, K.; Toral-Barza, L.; et al. Pyranonaphthoquinone lactones: A new class of AKT selective kinase inhibitors alkylate a regulatory loop cysteine. J. Med. Chem. 2009, 52, 2181-2184. [CrossRef] [PubMed]

37. Takano, S.; Hasuda, K.; Ito, A.; Koide, Y.; Ishii, F.; Haneda, I.; Chihara, S.; Koyama, Y. A new antibiotic, medermycin. J. Antibiot. 1976, 29, 765-768. [CrossRef]

38. Bergy, M.E. Kalafungin, a new broade spectrum antibiotic. J. Antibiot. 1968, 21, 454-457. [CrossRef]

39. Iwai, Y.; Kōra, A.; Takahashi, Y.; Hayashi, T.; Awaya, J.; Masuma, R.; Ōiwa, R.; Ōmura, S. Production of deoxyfrenolicin and a new antibiotic, frenolicin B by streptomyces roseofulvus strain AM-3867. J. Antibiot. 1978, 31, 959-965. [CrossRef]

40. Lee, K.-H.; Rice, G.K.; Hall, I.H.; Amarnath, V. Antitumor agents. 86. Synthesis and cytotoxicity of .alpha.-methylene-.gamma.lactone-bearing purines. J. Med. Chem. 1987, 30, 586-588. [CrossRef] [PubMed]

41. Huth, J.R.; Park, C.; Petros, A.M.; Kunzer, A.R.; Wendt, M.D.; Wang, X.; Lynch, C.L.; Mack, J.C.; Swift, K.M.; Judge, R.A.; et al. Discovery and Design of Novel HSP90 Inhibitors Using Multiple Fragment-based Design Strategies. Chem. Biol. Drug Des. 2007, 70, 1-12. [CrossRef] [PubMed]

42. Nozaki, Y.; Katayama, N.; Harada, S.; Ono, H.; Okazaki, H. Lactivicin, a naturally occurring non- $\beta$-lactam antibiotic having $\beta$-lactam-like action: Biological activities and mode of action. J. Antibiot. 1989, 42, 84-93. [CrossRef] [PubMed]

43. Nozaki, Y.; Katayama, N.; Ono, H.; Tsubotani, S.; Harada, S.; Okazaki, H.; Nakao, Y. Binding of a non- $\beta$-lactam antibiotic to penicillin-binding proteins. Nature 1987, 325, 179-180. [CrossRef] [PubMed]

44. Gal, Z.; Koncz, A.; Szabo, I.; Deak, E.; Benko, I.; Barabas, G.; Hernandi, F.; Kovacs, P. A synthetic $\gamma$-lactone group with $\beta$-lactamase inhibitory and sporulation initiation effects. J. Chemother. 2000, 12, 274-279. [CrossRef]

45. Pavlović, D.; Mutak, S.; Andreotti, D.; Biondi, S.; Cardullo, F.; Paio, A.; Piga, E.; Donati, D.; Lociuro, S. Synthesis and structureactivity relationships of $\alpha$-amino- $\gamma$-lactone ketolides: A novel class of macrolide antibiotics. ACS Med. Chem. Lett. 2014, 5, 1133-1137. [CrossRef] 
46. Kochikyan, T.V.; Arutyunyan, E.V.; Samvelyan, M.A.; Arutyunyan, V.S.; Avetisyan, A.A.; Paronikyan, R.V.; Stepanyan, G.M. Synthesis and antibacterial properties of hydrazonothiazolyl derivatives of saturated 2,4,4-substituted butanolides. Pharm. Chem. J. 2009, 43, 144-147. [CrossRef]

47. Mazur, M.; Gładkowski, W.; Podkowik, M.; Bania, J.; Nawrot, J.; Białońska, A.; Wawrzeńczyk, C. Lactones 43 . New biologically active lactones: $\beta$-cyclocitral derivatives. Pest Manag. Sci. 2014, 70, 286-294. [CrossRef]

48. Hamann, H.J.; Abutaleb, N.S.; Pal, R.; Seleem, M.N.; Ramachandran, P.V. $\beta, \gamma$-Diaryl $\alpha$-methylene- $\gamma$-butyrolactones as potent antibacterials against methicillin-resistant Staphylococcus aureus. Bioorg. Chem. 2020, 104, 104183. [CrossRef] [PubMed]

49. Gładkowski, W.; Skrobiszewski, A.; Mazur, M.; Siepka, M.; Pawlak, A.; Obmińska-Mrukowicz, B.; Białońska, A.; Poradowski, D.; Drynda, A.; Urbaniak, M. Synthesis and anticancer activity of novel halolactones with $\beta$-aryl substituents from simple aromatic aldehydes. Tetrahedron 2013, 69, 10414-10423. [CrossRef]

50. Włoch, A.; Stygar, D.; Bahri, F.; Bażanów, B.; Kuropka, P.; Chełmecka, E.; Pruchnik, H.; Gładkowski, W. Antiproliferative, antimicrobial and antiviral activity of $\beta$-aryl- $\delta$-iodo- $\gamma$-lactones, their effect on cellular oxidative stress markers and biological membranes. Biomolecules 2020, 10, 1594. [CrossRef] [PubMed]

51. Feng, J.T.; Ma, Z.Q.; Li, J.H.; He, J.; Xu, H.; Zhang, X. Synthesis and antifungal activity of carabrone derivatives. Molecules 2010, 15, 6485-6492. [CrossRef] [PubMed]

52. Jun-Tao, F.; De-Long, W.; Yong-Ling, W.; He, Y.; Xing, Z. New antifungal scaffold derived from a natural pharmacophore: Synthesis of $\alpha$-methylene- $\gamma$-butyrolactone derivatives and their antifungal activity against Colletotrichum lagenarium. Bioorganic Med. Chem. Lett. 2013, 23, 4393-4397. [CrossRef]

53. Wu, Y.; Wang, D.; Gao, Y.; Feng, J.; Zhang, X. New $\alpha$-methylene- $\gamma$-butyrolactone derivatives as potential fungicidal agents: Design, synthesis and antifungal activities. Molecules 2016, 21, 130. [CrossRef]

54. Björn Bode, H.; Irschik, H.; Wenzel, S.C.; Reichenbach, H.; Müller, R.; Höfle, G. The leupyrrins: A structurally unique family of secondary metabolites from the myxobacterium Sorangium cellulosum. J. Nat. Prod. 2003, 66, 1203-1206. [CrossRef]

55. Herkommer, D.; Thiede, S.; Wosniok, P.R.; Dreisigacker, S.; Tian, M.; Debnar, T.; Irschik, H.; Menche, D. Stereochemical determination of the leupyrrins and total synthesis of leupyrrin A1. J. Am. Chem. Soc. 2015, 137, 4086-4089. [CrossRef] [PubMed]

56. Wosniok, P.R.; Knopf, C.; Dreisigacker, S.; Orozco-Rodriguez, J.M.; Hinkelmann, B.; Mueller, P.P.; Brönstrup, M.; Menche, D. SAR Studies of the Leupyrrins: Design and Total Synthesis of Highly Potent Simplified Leupylogs. Chem. A Eur. J. 2020, 26, 15074-15078. [CrossRef]

57. Yang, N.; Wang, Q.-H.; Wang, W.-Q.; Wang, J.; Li, F.; Tan, S.-P.; Cheng, M.-S. The design, synthesis and in vitro immunosuppressive evaluation of novel isobenzofuran derivatives. Bioorg. Med. Chem. Lett. 2012, 22, 53-56. [CrossRef]

58. Reinhardt, J.K.; Klemd, A.M.; Danton, O.; De Mieri, M.; Smieško, M.; Huber, R.; Bürgi, T.; Gründemann, C.; Hamburger, M. Sesquiterpene Lactones from Artemisia argyi: Absolute Configuration and Immunosuppressant Activity. J. Nat. Prod. 2019, 82, 1424-1433. [CrossRef] [PubMed]

59. Chinthakindi, P.K.; Singh, J.; Gupta, S.; Nargotra, A.; Mahajan, P.; Kaul, A.; Ahmed, Z.; Koul, S.; Sangwan, P.L. Synthesis of $\alpha$-santonin derivatives for diminutive effect on $\mathrm{T}$ and B-cell proliferation and their structure activity relationships. Eur. J. Med. Chem. 2017, 127, 1047-1058. [CrossRef]

60. Xiang, M.; Liu, T.; Tan, W.; Ren, H.; Li, H.; Liu, J.; Cao, H.; Cheng, Q.; Liu, X.; Zhu, H.; et al. Effects of kinsenoside, a potential immunosuppressive drug for autoimmune hepatitis, on dendritic cells /CD8 + T cells communication in mice. Hepatology 2016, 64, 2135-2150. [CrossRef]

61. Zhang, Y.; Xiang, M. Kinsenoside Having Good Therapeutic Effect on Autoimmune Hepatitis (AIH), and Its Application and Preparation Method. CN106317142, 11 January 2017.

62. Liu, X.; Fu, J.; Yao, X.J.; Yang, J.; Liu, L.; Xie, T.G.; Jiang, P.C.; Jiang, Z.H.; Zhu, G.Y. Phenolic Constituents Isolated from the Twigs of Cinnamomum cassia and Their Potential Neuroprotective Effects. J. Nat. Prod. 2018, 81, 1333-1342. [CrossRef]

63. Wang, S.; Jin, D.Q.; Xie, C.; Wang, H.; Wang, M.; Xu, J.; Guo, Y. Isolation, characterization, and neuroprotective activities of sesquiterpenes from Petasites japonicus. Food Chem. 2013, 141, 2075-2082. [CrossRef] [PubMed]

64. Yang, S.; Wang, S.; Peng, N.; Xie, Z.; Wang, P.; Zhao, C.; Wei, L.; Yang, H.; Zhao, B.; Miao, J.; et al. Butyrolactone derivative 3-benzyl-5-((2-nitrophenoxy) methyl)-dihydrofuran- $2(3 \mathrm{H})$-one protects against amyloid- $\beta$ peptides-induced cytotoxicity in PC12 cells. J. Alzheimer's Dis. 2012, 28, 345-356. [CrossRef]

65. Wei, L.; Yang, H.; Xie, Z.; Yang, S.; Yang, H.; Zhao, C.; Wang, P.; Xu, S.; Miao, J.; Zhao, B.; et al. A Butyrolactone Derivative 3BDO Alleviates Memory Deficits and Reduces Amyloid- $\beta$ Deposition in an A $\beta P$ PS1 Transgenic Mouse Model. J. Alzheimer's Dis. 2012, 30, 531-543. [CrossRef]

66. Min, B.S.; Na, M.K.; Oh, S.R.; Ahn, K.S.; Jeong, G.S.; Li, G.; Lee, S.K.; Joung, H.; Lee, H.K. New furofuran and butyrolactone lignans with antioxidant activity from the stem bark of Styrax japonica. J. Nat. Prod. 2004, 67, 1980-1984. [CrossRef]

67. Lohezic-Le Devehat, F.; Tomasi, S.; Elix, J.A.; Bernard, A.; Rouaud, I.; Uriac, P.; Boustie, J. Stictic acid derivatives from the lichen Usnea articulata and their antioxidant activities. J. Nat. Prod. 2007, 70, 1218-1220. [CrossRef] [PubMed]

68. Wu, W.; Liu, L.; Zhu, H.; Sun, Y.; Wu, Y.; Liao, H.; Gui, Y.; Li, L.; Liu, L.; Sun, F.; et al. Butyrolactone-I, an efficient $\alpha$-glucosidase inhibitor, improves type 2 diabetes with potent TNF- $\alpha$-lowering properties through modulating gut microbiota in $\mathrm{db} / \mathrm{db}$ mice. FASEB J. 2019, 33, 12616-12629. [CrossRef]

69. Trécant, C.; Dlubala, A.; George, P.; Pichat, P.; Ripoche, I.; Troin, Y. Synthesis and biological evaluation of analogues of M6G. Eur. J. Med. Chem. 2011, 46, 4035-4041. [CrossRef] [PubMed] 
70. Prévost, C. Iodo-Silver Benzoate and Its Use in the Oxidation of Ethylene Derivatives into $\alpha$-Glycols. Compt. Rend 1933, 196, 1129-1131.

71. Woodward, R.B.; Brutcher, F.V., Jr. cis-Hydroxylation of a synthetic steroid intermediate with iodine, silver acetate and wet acetic acid. J. Am. Chem. Soc. 1958, 80, 209-211. [CrossRef]

72. Jacobsen, E.N.; Marko, I.; Mungall, W.S.; Schroeder, G.; Sharpless, K.B. Asymmetric dihydroxylation via ligand-accelerated catalysis. J. Am. Chem. Soc. 1988, 110, 1968-1970. [CrossRef]

73. Kang, Y.-B.; Gade, L.H. Triflic Acid Catalyzed Oxidative Lactonization and Diacetoxylation of Alkenes Using Peroxyacids as Oxidants. J. Org. Chem. 2012, 77, 1610-1615. [CrossRef]

74. Rosatella, A.A.; Afonso, C.A.M. Brønsted Acid-Catalyzed Dihydroxylation of Olefins in Aqueous Medium. Adv. Synth. Catal. 2011, 353, 2920-2926. [CrossRef]

75. Kang, Y.-B.; Chen, X.-M.; Yao, C.-Z.; Ning, X.-S. Direct oxidative lactonization of alkenoic acids mediated solely by $\mathrm{NaIO}_{4}$ : $\mathrm{Beyond}$ a simple oxidant. Chem. Commun. 2016, 52, 6193-6196. [CrossRef]

76. Triandafillidi, I.; Raftopoulou, M.; Savvidou, A.; Kokotos, C.G. Organocatalytic Synthesis of Lactones by the Oxidation of Alkenoic Acids. Chem CatChem 2017, 9, 4120-4124. [CrossRef]

77. Dagenais, R.; Lussier, T.; Legault, C.Y. Iodine(III)-Mediated Contraction of 3,4-Dihydropyranones: Access to Polysubstituted $\gamma$-Butyrolactones. Org. Lett. 2019, 21, 5290-5294. [CrossRef]

78. Karila, D.; Leman, L.; Dodd, R.H. Copper-Catalyzed Iminoiodane-Mediated Aminolactonization of Olefins: Application to the Synthesis of 5,5-Disubstituted Butyrolactones. Org. Lett. 2011, 13, 5830-5833. [CrossRef]

79. Evans, D.A.; Woerpel, K.A.; Hinman, M.M.; Faul, M.M. Bis(oxazolines) as chiral ligands in metal-catalyzed asymmetric reactions. Catalytic, asymmetric cyclopropanation of olefins. J. Am. Chem. Soc. 1991, 113, 726-728. [CrossRef]

80. Evans, D.A.; Bilodeau, M.T.; Faul, M.M. Development of the Copper-Catalyzed Olefin Aziridination Reaction. J. Am. Chem. Soc. 1994, 116, 2742-2753. [CrossRef]

81. Tamaru, Y.; Mizutani, M.; Furukawa, Y.; Kawamura, S.; Yoshida, Z.; Yanagi, K.; Minobe, M. 1,3-Asymmetric induction: Highly stereoselective synthesis of 2,4-trans-disubstituted $\gamma$-butyrolactones and $\gamma$-butyrothiolactones. J. Am. Chem. Soc. 1984, 106, 1079-1085. [CrossRef]

82. Evans, D.A.; Ennis, M.D.; Mathre, D.J. Asymmetric alkylation reactions of chiral imide enolates. A practical approach to the enantioselective synthesis of $\alpha$-substituted carboxylic acid derivatives. J. Am. Chem. Soc. 1982, 104, 1737-1739. [CrossRef]

83. Moriyama, K.; Izumisawa, Y.; Togo, H. Oxidative Intramolecular Bromo-Amination of $\mathrm{N}$-Alkenyl Sulfonamides via Umpolung of Alkali Metal Bromides. J. Org. Chem. 2011, 76, 7249-7255. [CrossRef]

84. Moriyama, K.; Sugiue, T.; Nishinohara, C.; Togo, H. Divergent Synthesis of $\alpha, \gamma$-Disubstituted $\gamma$-Butyrolactones through Diastereoselective Bromolactonization with Alkali Metal Bromide: Asymmetric Total Synthesis of (+)-Dubiusamine C. J. Org. Chem. 2015, 80, 9132-9140. [CrossRef] [PubMed]

85. Balkrishna, S.J.; Prasad, C.D.; Panini, P.; Detty, M.R.; Chopra, D.; Kumar, S. Isoselenazolones as Catalysts for the Activation of Bromine: Bromolactonization of Alkenoic Acids and Oxidation of Alcohols. J. Org. Chem. 2012, 77, 9541-9552. [CrossRef]

86. Detty, M.R.; Friedman, A.E.; McMillan, M. A Stepwise Mechanism for Oxidative Addition of Bromine to Organoselenium(II) and Organotellurium(II) Compounds. Organometallics 1994, 13, 3338-3345. [CrossRef]

87. Rosocha, G.; Batey, R.A. Synthesis of 2-bromo-1-aryl-1H-indenes via a Ag(I) promoted domino $2 \pi$-electrocyclic ring-opening/4 $\pi$ electrocyclization reaction of 1,2-diaryl substituted gem-dibromocyclopropanes. Tetrahedron 2013, 69, 8758-8768. [CrossRef]

88. Kalmode, H.P.; Handore, K.L.; Reddy, D.S. Access to Fused Tricyclic $\gamma$-Butyrolactones, A Natural Product-like Scaffold. J. Org. Chem. 2017, 82, 7614-7620. [CrossRef]

89. Kim, S.J.; Lough, A.J.; Batey, R.A. An Approach to the 9-Oxo-10-oxabicyclo[5.3.0]dec-2-ene Core of the Guaianolide and Pseudoguaianolide Sesquiterpenes via a Domino Electrocyclic Ring-Opening/Carboxylic Acid Trapping of a gemDibromocyclopropane. J. Org. Chem. 2018, 83, 13799-13810. [CrossRef]

90. Bandini, M.; Eichholzer, A. Enantioselective Gold-Catalyzed Allylic Alkylation of Indoles with Alcohols: An Efficient Route to Functionalized Tetrahydrocarbazoles. Angew. Chem. Int. Ed. 2009, 48, 9533-9537. [CrossRef]

91. Bandini, M.; Eichholzer, A.; Gualandi, A.; Quinto, T.; Savoia, D. Creating Chemical Diversity in Indole Compounds by Merging $\mathrm{Au}$ and Ru Catalysis. ChemCatChem 2010, 2, 661-665. [CrossRef]

92. Marion, N.; Gealageas, R.; Nolan, S.P. [(NHC)AuI]-Catalyzed Rearrangement of Allylic Acetates. Org. Lett. 2007, 9, $2653-2656$. [CrossRef] [PubMed]

93. Wang, Y.-H.; Zhu, L.-L.; Zhang, Y.-X.; Chen, Z. Diastereoselective $\gamma$-vinyl butyrolactone synthesis via gold catalyzed cyclization of allylic acetate. Chem. Commun. 2010, 46, 577-579. [CrossRef] [PubMed]

94. Chiarucci, M.; Locritani, M.; Cera, G.; Bandini, M. Gold(I)-catalyzed synthesis of $\gamma$-vinylbutyrolactones by intramolecular oxaallylic alkylation with alcohols. Beilstein J. Org. Chem. 2011, 7, 1198-1204. [CrossRef] [PubMed]

95. Liu, J.; Miotto, R.J.; Segard, J.; Erb, A.M.; Aponick, A. Catalytic Dehydrative Lactonization of Allylic Alcohols. Org. Lett. 2018, 20, 3034-3038. [CrossRef]

96. Okada, T.; Sakaguchi, K.; Shinada, T.; Ohfune, Y. Au-catalyzed cyclization of allenylsilanes. Regioselective conversion to 2-amino-4-silylmethylene $\gamma$-butyrolactone. Tetrahedron Lett. 2011, 52, 5740-5743. [CrossRef] 
97. Guo, W.; Cheng, H.-G.; Chen, L.-Y.; Xuan, J.; Feng, Z.-J.; Chen, J.-R.; Lu, L.-Q.; Xiao, W.-J. De Novo Synthesis of $\gamma, \gamma$-Disubstituted Butyrolactones through a Visible Light Photocatalytic Arylation-Lactonization Sequence. Adv. Synth. Catal. 2014, 356, $2787-2793$. [CrossRef]

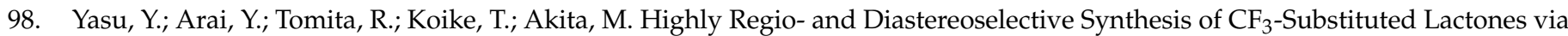
Photoredox-Catalyzed Carbolactonization of Alkenoic Acids. Org. Lett. 2014, 16, 780-783. [CrossRef]

99. Sha, W.; Ni, S.; Han, J.; Pan, Y. Access to Alkyl-Substituted Lactone via Photoredox-Catalyzed Alkylation/Lactonization of Unsaturated Carboxylic Acids. Org. Lett. 2017, 19, 5900-5903. [CrossRef] [PubMed]

100. Wei, X.-J.; Yang, D.-T.; Wang, L.; Song, T.; Wu, L.-Z.; Liu, Q. A Novel Intermolecular Synthesis of $\gamma$-Lactones via Visible-Light Photoredox Catalysis. Org. Lett. 2013, 15, 6054-6057. [CrossRef]

101. Montgomery, T.P.; Hassan, A.; Park, B.Y.; Krische, M.J. Enantioselective conversion of primary alcohols to $\alpha$-exo-methylene $\gamma$-butyrolactones via iridium-catalyzed C-C bond-forming transfer hydrogenation: 2-(Alkoxycarbonyl)allylation. J. Am. Chem. Soc. 2012, 134, 11100-11103. [CrossRef] [PubMed]

102. Spielmann, K.; Niel, G.; De Figueiredo, R.M.; Campagne, J.M. Catalytic nucleophilic "umpoled" $\pi$-allyl reagents. Chem. Soc. Rev. 2018, 47, 1159-1173. [CrossRef] [PubMed]

103. Leung, J.C.; Geary, L.M.; Chen, T.Y.; Zbieg, J.R.; Krische, M.J. Direct, redox-neutral prenylation and geranylation of secondary carbinol C-H bonds: C4-regioselectivity in ruthenium-catalyzed C-C couplings of dienes to $\alpha$-hydroxy esters. J. Am. Chem. Soc. 2012, 134, 15700-15703. [CrossRef] [PubMed]

104. McInturff, E.L.; Mowat, J.; Waldeck, A.R.; Krische, M.J. Ruthenium-catalyzed hydrohydroxyalkylation of acrylates with diols and $\alpha$-hydroxycarbonyl compounds to form spiro- and $\alpha$-methylene- $\gamma$ - butyrolactones. J. Am. Chem. Soc. 2013, 135, 17230-17235. [CrossRef] [PubMed]

105. Chen, W.; Yang, Q.; Zhou, T.; Tian, Q.; Zhang, G. Enantioselective Synthesis of $\alpha$-exo-Methylene $\gamma$-Butyrolactones via Chromium Catalysis. Org. Lett. 2015, 17, 5236-5239. [CrossRef]

106. McManus, H.A.; Guiry, P.J. Coupling of Bulky, Electron-Deficient Partners in Aryl Amination in the Preparation of Tridentate Bis(oxazoline) Ligands for Asymmetric Catalysis. J. Org. Chem. 2002, 67, 8566-8573. [CrossRef]

107. Murata, Y.; Takahashi, M.; Yagishita, F.; Sakamoto, M.; Sengoku, T.; Yoda, H. Construction of Spiro-Fused 2-Oxindole/ $\alpha-$ Methylene- $\gamma$-Butyrolactone Systems with Extremely High Enantioselectivity via Indium-Catalyzed Amide Allylation of $N$-Methyl Isatin. Org. Lett. 2013, 15, 6182-6185. [CrossRef] [PubMed]

108. Hoffmann, H.M.R.; Rabe, J. Synthesis and Biological Activity of $\alpha$-Methylene- $\gamma$-butyrolactones. Angew. Chem. Int. Ed. 1985, 24, 94-110. [CrossRef]

109. Takahashi, M.; Murata, Y.; Yagishita, F.; Sakamoto, M.; Sengoku, T.; Yoda, H. Catalytic enantioselective amide allylation of isatins and its application in the synthesis of 2-oxindole derivatives spiro-fused to the $\alpha$-methylene- $\gamma$-butyrolactone functionality. Chem. Eur. J. 2014, 20, 11091-11100. [CrossRef]

110. Nair, V.; Vellalath, S.; Babu, B.P. Recent advances in carbon-carbon bond-forming reactions involving homoenolates generated by NHC catalysis. Chem. Soc. Rev. 2008, 37, 2691. [CrossRef] [PubMed]

111. Sun, L.H.; Shen, L.T.; Ye, S. Highly diastereo- and enantioselective NHC-catalyzed [3+2] annulation of enals and isatins. Chem. Commun. 2011, 47, 10136-10138. [CrossRef]

112. Dugal-Tessier, J.; O’Bryan, E.A.; Schroeder, T.B.H.; Cohen, D.T.; Scheidt, K.A. An N-heterocyclic carbene/lewis acid strategy for the stereoselective synthesis of spirooxindole lactones. Angew. Chem. Int. Ed. 2012, 51, 4963-4967. [CrossRef]

113. Jin, Z.; Jiang, K.; Fu, Z.; Torres, J.; Zheng, P.; Yang, S.; Song, B.-A.; Chi, Y.R. Nucleophilic $\beta$-Carbon Activation of Propionic Acid as a 3-Carbon Synthon by Carbene Organocatalysis. Chem. Eur. J. 2015, 21, 9360-9363. [CrossRef] [PubMed]

114. Xie, Y.; Yu, C.; Li, T.; Tu, S.; Yao, C. An NHC-catalyzed in situ activation strategy to $\beta$-functionalize saturated carboxylic acid: An enantioselective formal [3+2] annulation for spirocyclic oxindolo- $\gamma$-butyrolactones. Chem. Eur. J. 2015, 21, 5355-5359. [CrossRef]

115. Xu, J.; Yuan, S.; Miao, M.; Chen, Z. 1-Hydroxybenzotriazole-Assisted, N-Heterocyclic Carbene Catalyzed $\beta$-Functionalization of Saturated Carboxylic Esters: Access to Spirooxindole Lactones. J. Org. Chem. 2016, 81, 11454-11460. [CrossRef]

116. Goodman, C.G.; Walker, M.M.; Johnson, J.S. Enantioconvergent synthesis of functionalized $\gamma$-butyrolactones via (3+2)-annulation J. Am. Chem. Soc. 2015, 137, 122-125. [CrossRef]

117. Shaw, M.H.; Twilton, J.; MacMillan, D.W.C. Photoredox Catalysis in Organic Chemistry. J. Org. Chem. 2016, 81, 6898-6926. [CrossRef] [PubMed]

118. Jeffrey, J.L.; Terrett, J.A.; MacMillant, D.W.C. O-H hydrogen bonding promotes H-atom transfer from $\alpha$ C-H bonds for C-alkylation of alcohols. Science 2015, 349, 1532-1536. [CrossRef]

119. Kaplaneris, N.; Bisticha, A.; Papadopoulos, G.N.; Limnios, D.; Kokotos, C.G. Photoorganocatalytic synthesis of lactones: Via a selective C-H activation-alkylation of alcohols. Green Chem. 2017, 19, 4451-4456. [CrossRef]

120. Shono, T.; Ohmizu, H.; Kawakami, S.; Sugiyama, H. Electroreductive hydrocoupling of activated olefins with ketones or aldehydes in the presence of trimethylchlorosilane. Tetrahedron Lett. 1980, 21, 5029-5032. [CrossRef]

121. Kise, N.; Hamada, Y.; Sakurai, T. Electroreductive coupling of optically active $\alpha, \beta$-unsaturated carbonyl compounds with diaryl ketones: Asymmetric synthesis of 4,5,5-trisubstituted $\gamma$-butyrolactones. Org. Lett. 2014, 16, 3348-3351. [CrossRef] [PubMed]

122. Cao, J.; Dong, S.; Jiang, D.; Zhu, P.; Zhang, H.; Li, R.; Li, Z.; Wang, X.; Tang, W.; Du, D. $\beta$-Functionalization of Indolin-2-oneDerived Aliphatic Acids for the Divergent Synthesis of Spirooxindole $\gamma$-Butyrolactones. J. Org. Chem. 2017, 82, 4186-4193. [CrossRef] 
123. Khopade, T.M.; Sonawane, A.D.; Arora, J.S.; Bhat, R.G. Direct Organocatalytic Multicomponent Synthesis of Enantiopure $\gamma$-Butyrolactones via Tandem Knoevenagel-Michael-Lactonization Sequence. Adv. Synth. Catal. 2017, 359, 3905-3910. [CrossRef]

124. Hamid, M.H.S.A.; Slatford, P.A.; Williams, J.M.J. Borrowing Hydrogen in the Activation of Alcohols. Adv. Synth. Catal. 2007, 349, 1555-1575. [CrossRef]

125. Kim, S.W.; Zhang, W.; Krische, M.J. Catalytic Enantioselective Carbonyl Allylation and Propargylation via Alcohol-Mediated Hydrogen Transfer: Merging the Chemistry of Grignard and Sabatier. Acc. Chem. Res. 2017, 50, 2371-2380. [CrossRef] [PubMed]

126. Peña-López, M.; Neumann, H.; Beller, M. Ruthenium pincer-catalyzed synthesis of substituted $\gamma$-butyrolactones using hydrogen autotransfer methodology. Chem. Commun. 2015, 51, 13082-13085. [CrossRef]

127. Keshavarz, M.; Ahmady, A.Z.; Mostoufi, A.; Mohtasham, N. One-pot green regioselesctive synthesis of $\gamma$-lactones from epoxides and ketene silyl acetals using 1,3-Dimethylimidazolium fluoride as a recoverable Metal-free catalyst. Molecules 2017, $22,1385$. [CrossRef] [PubMed]

128. Zeller, M.A.; Riener, M.; Nicewicz, D.A. Butyrolactone synthesis via polar radical crossover cycloaddition reactions: Diastereoselective syntheses of methylenolactocin and protolichesterinic acid. Org. Lett. 2014, 16, 4810-4813. [CrossRef] [PubMed]

129. Cavanaugh, C.L.; Nicewicz, D.A. Synthesis of $\alpha$-Benzyloxyamino- $\gamma$-butyrolactones via a Polar Radical Crossover Cycloaddition Reaction. Org. Lett. 2015, 17, 6082-6085. [CrossRef]

130. Triandafillidi, I.; Kokotou, M.G.; Kokotos, C.G. Photocatalytic Synthesis of $\gamma$-Lactones from Alkenes: High-Resolution Mass Spectrometry as a Tool to Study Photoredox Reactions. Org. Lett. 2018, 20, 36-39. [CrossRef] [PubMed]

131. Yousuf, S.K.; Mukherjee, D.; L, M.; Taneja, S.C. Highly regio-and stereoselective one-pot synthesis of carbohydrate-based butyrolactones. Org. Lett. 2011, 13, 576-579. [CrossRef]

132. Ye, Z.; Cai, X.; Li, J.; Dai, M. Catalytic Cyclopropanol Ring Opening for Divergent Syntheses of $\gamma$-Butyrolactones and $\delta$-Ketoesters Containing All-Carbon Quaternary Centers. ACS Catal. 2018, 8, 5907-5914. [CrossRef]

133. Grandjean, J.M.M.; Nicewicz, D.A. Synthesis of highly substituted tetrahydrofurans by catalytic polar-radical-crossover cycloadditions of alkenes and alkenols. Angew. Chem. Int. Ed. 2013, 52, 3967-3971. [CrossRef]

134. Gesmundo, N.J.; Grandjean, J.M.M.; Nicewicz, D.A. Amide and amine nucleophiles in polar radical crossover cycloadditions: Synthesis of $\gamma$-lactams and pyrrolidines. Org. Lett. 2015, 17, 1316-1319. [CrossRef] [PubMed]

135. Wu, X.F.; Fang, X.; Wu, L.; Jackstell, R.; Neumann, H.; Beller, M. Transition-metal-catalyzed carbonylation reactions of olefins and alkynes: A personal account. Acc. Chem. Res. 2014, 47, 1041-1053. [CrossRef] [PubMed]

136. Babjak, M.; Markovič, M.; Kandríková, B.; Gracza, T. Homogeneous cyclocarbonylation of alkenols with iron pentacarbonyl. Synth. 2014, 46, 809-816. [CrossRef]

137. Lopatka, P.; Markovič, M.; Koóš, P.; Ley, S.V.; Gracza, T. Continuous Pd-Catalyzed Carbonylative Cyclization Using Iron Pentacarbonyl as a CO Source. J. Org. Chem. 2019, 84, 14394-14406. [CrossRef]

138. Li, J.; Yang, S.; Wu, W.; Jiang, H. Novel palladium-catalyzed cascade carboxylative annulation to construct functionalized $\gamma$-lactones in ionic liquids. Chem. Commun. 2014, 50, 1381-1383. [CrossRef] [PubMed]

139. Yang, S.-R.; Jiang, H.-F.; Li, Y.-Q.; Chen, H.-J.; Luo, W.; Xu, Y.-B. Protonolysis of the carbon-palladium bond in palladium(II)catalyzed enyne cyclization in imidazolium-type ionic liquids. Tetrahedron 2008, 64, 2930-2937. [CrossRef]

140. Higashimae, S.; Tamai, T.; Nomoto, A.; Ogawa, A. Selective Thiolative Lactonization of Internal Alkynes Bearing a Hydroxyl Group with Carbon Monoxide and Organic Disulfides Catalyzed by Transition-Metal Complexes. J. Org. Chem. 2015, 80, 7126-7133. [CrossRef] [PubMed]

141. Rosa, D.; Nikolaev, A.; Nithiy, N.; Orellana, A. Palladium-Catalyzed Cross-Coupling Reactions of Cyclopropanols. Synlett 2015, $26,441-448$.

142. Davis, D.C.; Walker, K.L.; Hu, C.; Zare, R.N.; Waymouth, R.M.; Dai, M. Catalytic Carbonylative Spirolactonization of Hydroxycyclopropanols. J. Am. Chem. Soc. 2016, 138, 10693-10699. [CrossRef]

143. Breit, B. Synthetic aspects of stereoselective hydroformylation. Acc. Chem. Res. 2003, 36, 264-275. [CrossRef] [PubMed]

144. Ueki, Y.; Ito, H.; Usui, I.; Breit, B. Formation of quaternary carbon centers by highly regioselective hydroformylation with catalytic amounts of a reversibly bound directing group. Chem. Eur. J. 2011, 17, 8555-8558. [CrossRef] [PubMed]

145. Deng, Y.; Wang, H.; Sun, Y.; Wang, X. Principles and Applications of Enantioselective Hydroformylation of Terminal Disubstituted Alkenes. ACS Catal. 2015, 5, 6828-6837. [CrossRef]

146. You, C.; Li, S.; Li, X.; Lv, H.; Zhang, X. Enantioselective Rh-Catalyzed Anti-Markovnikov Hydroformylation of 1,1-Disubstituted Allylic Alcohols and Amines: An Efficient Route to Chiral Lactones and Lactams. ACS Catal. 2019, 9, 8529-8533. [CrossRef]

147. Li, S.; Ma, S. Highly selective nickel-catalyzed methyl-carboxylation of homopropargylic alcohols for $\alpha$-alkylidene- $\gamma$;butyrolactones. Org. Lett. 2011, 13, 6046-6049. [CrossRef] [PubMed]

148. Li, S.; Ma, S. CO 2-activation for $\gamma$-butyrolactones and its application in the total synthesis of ( \pm )-heteroplexisolide e. Chem. Asian J. 2012, 7, 2411-2418. [CrossRef]

149. Lloyd, M.G.; Taylor, R.J.K.; Unsworth, W.P. A One-Pot C-H Insertion/Olefination Sequence for the Formation of $\alpha$-Alkylidene- $\gamma$ butyrolactones. Org. Lett. 2014, 16, 2772-2775. [CrossRef] [PubMed]

150. Lloyd, M.G.; D’Acunto, M.; Taylor, R.J.K.; Unsworth, W.P. $\alpha$-Alkylidene- $\gamma$-butyrolactone synthesis via one-pot C-H insertion/olefination: Substrate scope and the total synthesis of $( \pm$ )-cedarmycins A and B. Tetrahedron 2015, 71, 7107-7123. [CrossRef]

151. Lloyd, M.G.; D'Acunto, M.; Taylor, R.J.K.; Unsworth, W.P. A selective C-H insertion/olefination protocol for the synthesis of $\alpha$-methylene- $\gamma$-butyrolactone natural products. Org. Biomol. Chem. 2016, 14, 1641-1645. [CrossRef] [PubMed] 
152. Schwarz, W.; Schossig, J.; Rossbacher, R.; Pinkos, R.; Höke, H. Butyrolactone. In Ullmann's Encyclopedia of Industrial Chemistry; Wiley: Weinheim, Germany, 2019; pp. 1-7, ISBN 9783527306732.

153. Yim, H.; Haselbeck, R.; Niu, W.; Pujol-Baxley, C.; Burgard, A.; Boldt, J.; Khandurina, J.; Trawick, J.D.; Osterhout, R.E.; Stephen, R.; et al. Metabolic engineering of Escherichia coli for direct production of 1,4-butanediol. Nat. Chem. Biol. 2011, 7, 445-452. [CrossRef] [PubMed]

154. Hwang, D.W.; Kashinathan, P.; Lee, J.M.; Lee, J.H.; Lee, U.; Hwang, J.-S.; Hwang, Y.K.; Chang, J.-S. Production of $\gamma$-butyrolactone from biomass-derived 1,4-butanediol over novel copper-silica nanocomposite. Green Chem. 2011, 13, 1672. [CrossRef]

155. Zhang, B.; Zhu, Y.; Ding, G.; Zheng, H.; Li, Y. Modification of the supported $\mathrm{Cu} / \mathrm{SiO}_{2}$ catalyst by alkaline earth metals in the selective conversion of 1,4-butanediol to $\gamma$-butyrolactone. Appl. Catal. A Gen. 2012, 443-444, 191-201. [CrossRef]

156. Reddy, K.H.P.; Anand, N.; Venkateswarlu, V.; Rao, K.S.R.; Burri, D.R. A selective synthesis of 1-phenylethanol and $\gamma$-butyrolactone through coupling processes over $\mathrm{Cu} / \mathrm{MgO}$ catalysts. J. Mol. Catal. A Chem. 2012, 355, 180-185. [CrossRef]

157. Hu, Q.; Fan, G.; Yang, L.; Cao, X.; Zhang, P.; Wang, B.; Li, F. A gas-phase coupling process for simultaneous production of $\gamma$-butyrolactone and furfuryl alcohol without external hydrogen over bifunctional base-metal heterogeneous catalysts. Green Chem. 2016, 18, 2317-2322. [CrossRef]

158. Prasad, H.; Kannapu, R.; Suh, Y.W.; Narani, A. Coupling of 1,4-Butanediol Dehydrogenation with Nitrobenzene Hydrogenation for Simultaneous Synthesis of $\gamma$-Butyrolactone and Aniline over Promoted Cu-MgO Catalysts: Effect of Promoters. Catal. Lett. 2017, 147, 90-101.

159. Hari, K.; Reddy, P.; Suh, Y.; Anand, N.; David, B.; Seetha, K.; Rao, R. Coupling of ortho-chloronitrobenzene hydrogenation with 1,4-butanediol dehydrogenation over Cu-MgO catalysts: A hydrogen free process. Catal. Commun. 2017, 95, 21-25.

160. Nagaiah, P.; Venkat Rao, M.; Thirupathaiah, K.; Venkateshwarlu, V.; David Raju, B.; Rama Rao, K.S. Selective vapour phase dehydrogenation of biomass-derived 1,4-butanediol to gamma butyrolactone over $\mathrm{Cu} / \mathrm{ZrO}_{2}$ catalysts: Influence of La $\mathrm{O}_{3}$ promotor. Res. Chem. Intermed. 2018, 44, 5817-5831. [CrossRef]

161. Bhanushali, J.T.; Prasad, D.; Patil, K.N.; Reddy, K.S.; Rama Rao, K.S.; Jadhav, A.H.; Nagaraja, B.M. Simultaneous dehydrogenation of 1,4-butanediol to $\gamma$-butyrolactone and hydrogenation of benzaldehyde to benzyl alcohol mediated over competent $\mathrm{CeO}_{2}-\mathrm{Al}_{2} \mathrm{O}_{3}$ supported $\mathrm{Cu}$ as catalyst. Int. J. Hydrogen Energy 2020, 45, 12874-12888. [CrossRef]

162. Aellig, C.; Jenny, F.; Scholz, D.; Wolf, P.; Giovinazzo, I.; Kollhoff, F.; Hermans, I. Combined 1,4-butanediol lactonization and transfer hydrogenation/hydrogenolysis of furfural-derivatives under continuous flow conditions. Catal. Sci. Technol. 2014, 4, 2326-2331. [CrossRef]

163. Huang, L.; Romero, E.; Ressmann, A.K.; Rudroff, F.; Hollmann, F.; Fraaije, M.W.; Kara, S. Nicotinamide Adenine DinucleotideDependent Redox-Neutral Convergent Cascade for Lactonizations with Type II Flavin-Containing Monooxygenase. Adv. Synth. Catal. 2017, 359, 2142-2148. [CrossRef]

164. Kara, S.; Spickermann, D.; Schrittwieser, J.H.; Weckbecker, A.; Leggewie, C.; Arends, I.W.C.E.; Hollmann, F. Access to Lactone Building Blocks via Horse Liver Alcohol Dehydrogenase-Catalyzed Oxidative Lactonization. ACS Catal. 2013, 3, $2436-2439$. [CrossRef]

165. Li, X.; Zheng, J.; Yang, X.; Dai, W.; Fan, K. Preparation and application of highly efficient Au/SnO 2 catalyst in the oxidative lactonization of 1,4-butanediol to $\gamma$-butyrolactone. Chin. J. Catal. 2013, 34, 1013-1019. [CrossRef]

166. Li, X.; Cui, Y.; Yang, X.; Dai, W.; Fan, K. Highly efficient and stable Au/ $\mathrm{Mn}_{2} \mathrm{O}_{3}$ catalyst for oxidative cyclization of 1,4-butanediol to $\gamma$-butyrolactone. Appl. Catal. A Gen. 2013, 458, 63-70. [CrossRef]

167. Xie, X.; Stahl, S.S. Efficient and Selective Cu/Nitroxyl-Catalyzed Methods for Aerobic Oxidative Lactonization of Diols. J. Am. Chem. Soc. 2015, 137, 3767-3770. [CrossRef]

168. Chakraborty, S.; Lagaditis, P.O.; Förster, M.; Bielinski, E.A.; Hazari, N.; Holthausen, M.C.; Jones, W.D.; Schneider, S. Well-Defined Iron Catalysts for the Acceptorless Reversible Dehydrogenation-Hydrogenation of Alcohols and Ketones. ACS Catal. 2014, 4, 3994-4003. [CrossRef]

169. Tang, Y.; Meador, R.I.L.; Malinchak, C.T.; Harrison, E.E.; McCaskey, K.A.; Hempel, M.C.; Funk, T.W. (Cyclopentadienone)ironCatalyzed Transfer Dehydrogenation of Symmetrical and Unsymmetrical Diols to Lactones. J. Org. Chem. 2020, 85, 1823-1834. [CrossRef]

170. Coleman, M.G.; Brown, A.N.; Bolton, B.A.; Guan, H. Iron-Catalyzed Oppenauer-Type Oxidation of Alcohols. Adv. Synth. Catal. 2010, 352, 967-970. [CrossRef]

171. Peña-López, M.; Neumann, H.; Beller, M. Iron(II) Pincer-Catalyzed Synthesis of Lactones and Lactams through a Versatile Dehydrogenative Domino Sequence. ChemCatChem 2015, 7, 865-871. [CrossRef] 